\title{
Pan-Eurasian Experiment (PEEX): towards a holistic understanding of the feedbacks and interactions in the land-atmosphere-ocean-society continuum in the northern
}

\section{Eurasian region}

Hanna K. Lappalainen ${ }^{1,2,36}$, Veli-Matti Kerminen ${ }^{1}$, Tuukka Petäjä ${ }^{1,36}$, Theo Kurten ${ }^{3}$, Aleksander Baklanov ${ }^{4,5}$, Anatoly Shvidenko ${ }^{6}$, Jaana Bäck ${ }^{7}$, Timo Vihma ${ }^{2}$, Pavel Alekseychik ${ }^{1}$, Meinrat O. Andreae ${ }^{8}$, Stephen R. Arnold ${ }^{9}$, Mikhail Arshinov ${ }^{10}$, Eija Asmi ${ }^{2}$, Boris Belan ${ }^{10}$, Leonid Bobylev ${ }^{11}$, Sergey Chalov ${ }^{12}$, Yafang Cheng ${ }^{8}$, Natalia Chubarova $^{12}$, Gerrit de Leeuw ${ }^{1,2}$, Aijun Ding ${ }^{13}$, Sergey Dobrolyubov ${ }^{12}$, Sergei Dubtsov ${ }^{14}$, Egor Dyukarev ${ }^{15}$, Nikolai Elansky $^{16}$, Kostas Eleftheriadis ${ }^{17}$, Igor Esau ${ }^{18}$, Nikolay Filatov ${ }^{19}$, Mikhail Flint ${ }^{20}$, Congbin Fu ${ }^{13}$, Olga Glezer $^{21}$, Aleksander Gliko ${ }^{22}$, Martin Heimann ${ }^{23}$, Albert A. M. Holtslag ${ }^{24}$, Urmas Hõrrak ${ }^{25}$, Juha Janhunen ${ }^{26}$, Sirkku Juhola $^{27}$, Leena Järvi ${ }^{1}$, Heikki Järvinen ${ }^{1}$, Anna Kanukhina ${ }^{28}$, Pavel Konstantinov ${ }^{12}$, Vladimir Kotlyakov $^{29}$, Antti-Jussi Kieloaho ${ }^{1}$, Alexander S. Komarov ${ }^{30}$, Joni Kujansuu ${ }^{1}$, Ilmo Kukkonen ${ }^{31}$, Ella-Maria Duplissy ${ }^{1}$, Ari Laaksonen ${ }^{2}$, Tuomas Laurila ${ }^{2}$, Heikki Lihavainen ${ }^{2}$, Alexander Lisitzin ${ }^{20}$, Alexsander Mahura ${ }^{5}$, Alexander Makshtas ${ }^{32}$, Evgeny Mareev ${ }^{33}$, Stephany Mazon $^{1}$, Dmitry Matishov $^{34, \dagger}$, Vladimir Melnikov $^{35,36}$, Eugene Mikhailov ${ }^{37}$, Dmitri Moisseev ${ }^{1}$, Robert Nigmatulin ${ }^{20}$, Steffen M. Noe ${ }^{38}$, Anne Ojala ${ }^{7}$, Mari Pihlatie ${ }^{1}$, Olga Popovicheva ${ }^{39}$, Jukka Pumpanen ${ }^{40}$, Tatjana Regerand ${ }^{19}$, Irina Repina ${ }^{16}$, Aleksei Shcherbinin ${ }^{27}$, Vladimir Shevchenko ${ }^{20}$, Mikko Sipilä $^{1}$, Andrey Skorokhod ${ }^{16}$, Dominick V. Spracklen ${ }^{9}$, Hang Su$^{8}$, Dmitry A. Subetto ${ }^{19}$, Junying Sun ${ }^{41}$, Arkady Y. Terzhevik ${ }^{19}$, Yuri Timofeyev ${ }^{37}$, Yuliya Troitskaya ${ }^{33}$, Veli-Pekka Tynkkynen $^{42}$, Viacheslav I. Kharuk ${ }^{43}$, Nina Zaytseva ${ }^{22}$, Jiahua Zhang ${ }^{44}$, Yrjö Viisanen ${ }^{2}$, Timo Vesala ${ }^{1}$, Pertti Hari $^{7}$, Hans Christen Hansson ${ }^{45}$, Gennady G. Matvienko ${ }^{10}$, Nikolai S. Kasimov ${ }^{12}$, Huadong Guo $^{44}$, Valery Bondur $^{46}$, Sergej Zilitinkevich ${ }^{1,2,12,33}$, and Markku Kulmala ${ }^{1,36}$

${ }^{1}$ Department of Physics, University of Helsinki, 00014 Helsinki, Finland

${ }^{2}$ Research and Development, Finnish Meteorological Institute, 00101 Helsinki, Finland

${ }^{3}$ Department of Chemistry, University of Helsinki, 00014 Helsinki, Finland

${ }^{4}$ World Meteorological Organization, 1211 Geneva, Switzerland

${ }^{5}$ Research and Development Department, Danish Meteorological Institute, 2100 Copenhagen, Denmark

${ }^{6}$ Ecosystem Services and Management, International Institute for Applied Systems Analysis, 2361 Laxenburg, Austria

${ }^{7}$ Department of Forest Sciences, University of Helsinki, 00014 Helsinki, Finland

${ }^{8}$ Biogeochemistry and Multiphase Chemistry Departments, Max Planck Institute for Chemistry, 55020 Mainz, Germany

${ }^{9}$ Institute for Climate and Atmospheric Science, School of Earth and Environment, University of Leeds, Leeds, LS2 9JT, UK

${ }^{10}$ Institute of Atmospheric Optics, Russian Academy of Sciences, Tomsk 634021, Russia

${ }^{11}$ Nansen International Environmental and Remote Sensing Center, St. Petersburg, Russia

${ }^{12}$ Faculty of Geography, Lomonosov Moscow State University, Moscow 119899, Russia

${ }^{13}$ Institute for Climate and Global Change Research \& School of Atmospheric Sciences,

Nanjing University, 210023 Nanjing, China

${ }^{14}$ Institute of Chemical Kinetics \& Combustion, Russian Academy of Sciences, 630090 Novosibirsk, Russia

${ }^{15}$ Institute of Monitoring of Climatic \& Ecological Systems SB RAS, 634055 Tomsk, Russia

${ }^{16}$ A. M. Obukhov Institute of Atmospheric Physics, Russian Academy of Sciences, Moscow, Russia

${ }^{17}$ National Centre of Scientific Research "DEMOKRITOS", Athens, Greece

${ }^{18}$ Nansen Environmental and Remote Sensing Center/Bjerknes Centre for Climate Research, 5006 Bergen, Norway

${ }^{19}$ Northern Water Problems Institute, Karelian Research Center, Russian Academy of Sciences, 185003 Petrozavodsk, Russia 
${ }^{20}$ P. P. Shirshov, Institute of Oceanology, Russian Academy of Sciences, Russian Academy of Sciences, 117997 Moscow, Russia

${ }^{21}$ Institute of Geography, Russian Academy of Sciences, Moscow, Russia

${ }^{22}$ Department of Earth Sciences of the Russian Academy of Sciences, Russian Academy of Sciences, 119991 Moscow, Russia

${ }^{23}$ Max-Planck-Institute for Biogeochemistry, 07745 Jena, Germany

${ }^{24}$ Meteorology and Air Quality, Wageningen University, 6708 Wageningen, the Netherlands

${ }^{25}$ Institute of Physics, University of Tartu, 18 Ülikooli St., 50090 Tartu, Estonia

${ }^{26}$ Department of World Cultures, University of Helsinki, 00014 Helsinki, Finland

${ }^{27}$ Department of Environmental Sciences, University of Helsinki, 00014 Helsinki, Finland

${ }^{28}$ Academic Mobility Department, Russian State Hydrometeorological University, 195196 Saint Petersburg, Russia

${ }^{29}$ Institute of Geography, Russian Academy of Sciences, Moscow, Russia

${ }^{30}$ Institute of Physico-chemical \& Biological Problems in Soil Science, Russian Academy of Sciences, 142290 Institutskaya, Russia

${ }^{31}$ Geophysics and Astronomy, University of Helsinki, 00014 Helsinki, Finland

${ }^{32}$ Actic \& Antarctic Research Institute, Russian Academy of Sciences, 199397 St. Petersburg, Russia

${ }^{33}$ Department of Radiophysics, Nizhny Novgorod State University, Nizhny Novgorod, Russia

${ }^{34}$ Southern Center of Russian Academy of Sciences, Rostov on Don, Russia

${ }^{35}$ Tyumen Scientific Center, Siberian Branch, Russian Academy of Science, Tyumen, Russia

${ }^{36}$ Department of Cryosphere, Tyumen State University, 625003 Tyumen, Russia

${ }^{37}$ Department of Atmospheric Physics, Saint Petersburg State University, 7/9 Universitetskaya nab., 199034 St. Petersburg Russia

${ }^{38}$ Institute of Agricultural and Environmental Sciences, Estonian University of Life Sciences, 51014 Tartu, Estonia

${ }^{39}$ Department Microelectronics, Skobeltsyn Institute of Nuclear Physics, Moscow State University, Moscow 119991, Russia

${ }^{40}$ Department of Environmental Science, University of Eastern Finland, P.O. Box 1627, 70211 Kuopio, Finland

${ }^{41}$ Graduate University of Chinese Academy of Sciences, 100049 Beijing, China

${ }^{42}$ Aleksanteri Institute, Department of Social Research, University of Helsinki, 00014 Helsinki, Finland

${ }^{43}$ Sukachev Forest Institute, Russian Academy of Sciences, Krasnoyarsk 660036, Russia

${ }^{44}$ Institute of Remote Sensing and Digital Earth, Chinese Academy of Sciences, 100094 Beijing, China

${ }^{45}$ Environmental Science and Analytical Chemistry, Stockholm University, Stockholm, Sweden

${ }^{46}$ AEROCOSMOS Research Institute for Aerospace Monitoring, 105064 Moscow, Russia

$\dagger$ deceased, 20 August 2015

Correspondence to: Hanna K. Lappalainen (hanna.k.lappalainen@helsinki.fi)

Received: 2 March 2016 - Published in Atmos. Chem. Phys. Discuss.: 6 April 2016

Revised: 20 September 2016 - Accepted: 22 September 2016 - Published: 22 November 2016

\begin{abstract}
The northern Eurasian regions and Arctic Ocean will very likely undergo substantial changes during the next decades. The Arctic-boreal natural environments play a crucial role in the global climate via albedo change, carbon sources and sinks as well as atmospheric aerosol production from biogenic volatile organic compounds. Furthermore, it is expected that global trade activities, demographic movement, and use of natural resources will be increasing in the Arctic regions. There is a need for a novel research approach, which not only identifies and tackles the relevant multi-disciplinary research questions, but also is able to make a holistic system analysis of the expected feedbacks. In this paper, we introduce the research agenda of the Pan-Eurasian Experiment (PEEX), a multi-scale, multi-disciplinary and international program started in 2012 (https://www.atm.helsinki.fi/peex/).
\end{abstract}

PEEX sets a research approach by which large-scale research topics are investigated from a system perspective and which aims to fill the key gaps in our understanding of the feedbacks and interactions between the land-atmosphereaquatic-society continuum in the northern Eurasian region. We introduce here the state of the art for the key topics in the PEEX research agenda and present the future prospects of the research, which we see relevant in this context.

\section{Introduction}

The global environment is changing rapidly due to anthropogenic influences. As a result, we are already facing several "grand challenges" in the 21 st century (e.g. Smith, 2010; 
Bony et al., 2015; IPCC, 2013; Randers, 2012). Two of these challenges, climate change and air quality, are strongly influenced by human activities and their impacts on changing atmospheric composition, more specifically on the concentrations of greenhouse gases (GHG), reactive trace gases, and aerosol particles. In the future, the Arctic-boreal natural environment will play a crucial role in the global climate via albedo changes, carbon sources and sinks as well as aerosol production from biogenic volatile organic compounds (Arneth et al., 2010, 2014; Ballantyne et al., 2012; Carslaw et al., 2010; M. Kulmala et al., 2014, 2015).

In order to advance our understanding on interlinked grand challenges further, we need a research approach that helps us to construct a holistic scientific understanding of the feedbacks and interactions within the continuum of land-atmosphere-aquatic systems and society across different spatial and temporal scales. Therefore, we have established the Pan-Eurasian Experiment (PEEX) program (https://www.atm.helsinki.fi/peex/), which is a multi-scale, multi-disciplinary research initiative focusing on understanding biosphere-ocean-cryosphere-climate-society interactions and feedbacks (Lappalainen et al., 2014; Kulmala et al., 2015). PEEX fills some of the most critical scientific gaps needed for a holistic understanding of the feedback mechanisms characteristic of the northern Eurasian geographical domain. Boreal forests and peat lands characterize the vast land areas of northern Eurasia, with a major part of them situated inside Russian territory. In addition to natural environments, the PEEX research program is also interested in different human-influenced environments: from urban to countryside, from megacities to non-populated remote areas, from areas of dispersed settlements and sparselybuilt environments to heavily industrialized regions. Thus, the research approach covers the Arctic and boreal regions situated in northern Eurasia, and also the marine environments of the Arctic Ocean. PEEX operates in an integrative way using tools from natural and social sciences such as in situ and satellite observations, laboratory experiments, multi-scale models, and statistical data analyses, together with socio-economic analyses. The PEEX research agenda covers spatial scales from regional to global and temporal scales and from seconds to decades (Kulmala et al., 2011b). The scientific results will be used for developing new climate scenarios on global and regional scales, for constructing reliable early warning systems, and for the mitigation and adaptation planning of the northern societies in the most efficient way. PEEX aims to contribute to climate policy concerning topics important to the Northern Eurasian environment, helping societies build a sustainable future.

\section{System perspective approach}

Earth (system) sciences (ESS) has emerged as one of the most rapidly developing scientific fields. The recent growth of ESS has been facilitated by the importance of understanding the fundamental scientific processes of climate change and air quality as well as the increasing societal impact of this research area. The development has mainly taken place among natural sciences, while the collaboration between natural and social sciences to tackle climate change issues has started to emerge relatively slowly. A multi- and crossdisciplinary approach is thus needed to advance the solutionoriented understanding of grand challenges and to apply new knowledge for reliable climate scenario development, mitigation, and adaptation as well as early warning system development. In addition to enhanced collaboration between different branches of science, there is a need for a next generation of multi-disciplinary scientists able to connect the scientific issues with an understanding of the societal dimensions related to the grand challenges.

Climate change can be considered as the main driving force for system changes and their feedback dynamics, especially in the Arctic-boreal regions. It has already been estimated that the future warming in northern high latitudes regions will be, on average, larger than that experienced at lower latitudes (IPCC, 2013, 2014). The climate-changedriven processes taking place in the Arctic provide a good example of how important it is to quantify feedback dynamics and at the same time study the specific research topics from the land-atmosphere-hydrosphere-cryospheresocietal system perspective. For example, the surface radiation balance regulates the melting and freezing of the pack ice, which in turn is a key climate regulator. Model simulations of Arctic clouds are particularly deficient, impeding correctly simulated radiative fluxes, which are vital for the estimation of the snow-/ice-albedo feedback (Vavrus et al., 2009). Important, yet poorly quantified, players in the Arctic atmospheric system and climate change are the short-lived climate forcers (SLCF), such as black carbon and ozone. The climatic impacts of SLCFs are tightly connected with cryospheric changes of the land system, and associated with human activities. Models display diverse and often poor skill in simulating SLCF abundances both at the surface and vertically through the troposphere at high latitudes (Eckhardt et al., 2015; Emmons et al., 2015; Monks et al., 2015).

PEEX is setting a research approach where the large-scale research questions are studied from a system perspective, and which is also filling the key gaps in our understanding of the feedbacks and interactions between the land, atmosphere, aquatic, and societal systems in the northern Eurasian region (Kulmala et al., 2015). We have structured the research agenda so that we have highlighted three thematic research areas per system (Fig. 1). The identification of these key thematic research areas has been based on a bottom-up approach by researchers coming from Europe, Russia, and China, who have participated in PEEX meetings and conferences since 2012. These researchers first introduced a wide spectrum of specific research topics relevant to the Northern Eurasian region, which were then evaluated and classified. 


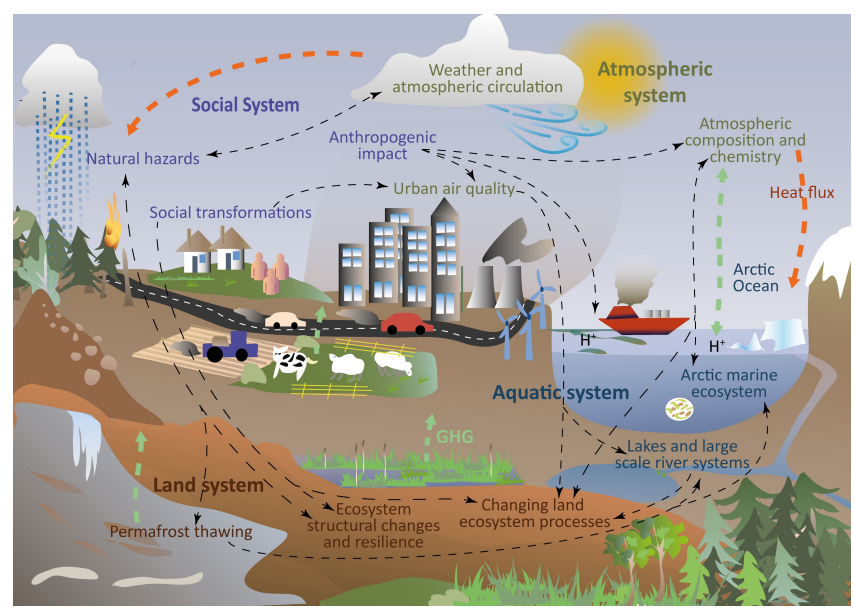

Figure 1. The thematic research areas relevant to the Northern Eurasian land system include land topic 1 "changing ecosystem processes", land topic 2 "ecosystem structural changes and resilience" and land topic 3 "risk areas of permafrost thawing". For the atmospheric system they are atmosphere topic 1 "atmospheric composition and chemistry", atmosphere topic 2 "Urban air quality", are atmosphere topic 3, "atmospheric circulation and weather", for the aquatic system they are aquatic topic 1 "Arctic Ocean in the climate system", aquatic topic 2 "maritime ecosystems", aquatic topic 3 "Lakes and large river systems", and for the social system they are society topic 1 "natural resources and anthropogenic activities", society topic 2 "natural hazards" and society topic 3 "social transformations".

This bottom-up process led to the so-called "system-based" structure with altogether 12 thematic research areas. This approach will piece by piece lead into a holistic system understanding, quantifying the dominant feedbacks and interactions between the systems, and providing an understanding of the dynamics of Arctic-boreal biogeochemical cycles (e.g. water, carbon, nitrogen, phosphorus, sulfur). In our approach, climate change is the key driver in the dynamics of the land, atmosphere, aquatic and societal systems (Kulmala et al., 2015). The large-scale thematic areas of each system and many of the research highlight topics introduced by the PEEX research agenda are fundamentally related to climatechange-driven shifting GHG and SLCF formation processes and their primary and secondary feedbacks between socioeconomic and biogeochemical systems. When studying the Arctic-boreal feedback loops in a wider context, the PEEX agenda addresses China as the most crucial source area of atmospheric pollution, having a significant impact on the chemical composition of the atmosphere over northern Eurasia (Monks et al., 2015). One must keep in mind that solving air quality-climate interactions is also the key to practical solutions on local air quality problems in China.

In this paper, we introduce the state of the art of the selected thematic research areas and summarize the future research needs at large scale. This introduction acts as a "White Paper" of the PEEX research community. The the- matic research areas relevant to the land system are related to "Changing land ecosystem processes" (Sect. 2.1.1), "Ecosystem structural changes and resilience" (Sect. 2.1.2), and "Risk areas of permafrost thawing" (Sect. 2.1.2). In the land system research agenda, we address the following key issues: changing boreal forests biomass, Arctic greening, and permafrost processes. The main research areas of the atmospheric system research are the specific characterization of the "Atmospheric composition and chemistry" (Sect. 2.2.1), "Urban air quality" (Sect. 2.2.2.), and the "Atmospheric circulation and weather" (Sect. 2.2.3). In terms of atmospheric systems, we address oxidants, trace gases, greenhouse gases, and aerosols as atmospheric key components. We highlight that future advances in predicting urban air quality and improving weather forecasting are strongly based in atmospheric boundary layer dynamics research (Holtslag et al., 2013).

The thematic research areas relevant to the Aquatic System are "the Arctic Ocean in the climate system" (Sect. 2.3.1), the "Arctic maritime ecosystems" (Sect. 2.3.2), and the "Lakes, wetland, and large-scale rivers systems" (Sect. 2.3.3). Under these research areas, we focus on topics like Arctic sea ice changes, marine gross primary production, and Arctic pelagic food webs under environmental changes. Lakes and large-scale river systems have multiple roles and aspects of the physical environments, starting from water chemistry and algal blooms, and ending up with carbon and methane dynamics.

The thematic areas of the societal system have a number of dimensions, but in the first phase the primary interest lies on studying the consequences of "Land use and natural resources" (Sect. 2.4.1), on the growing number of "Natural hazards" (Sect. 2.4.2), and on the "Social transformations" (Sect. 2.4.3) in the northern Eurasian region. We see topics like the future Siberian forest area together with fuel balance, forest fires effecting the carbon and nitrogen balance, and societal dimensions related to infrastructure degradation as the most important future research areas. In Sect. 3, we investigate the connections and interlinks between those four systems.

\subsection{Land system - state of the art and future research needs}

\subsubsection{Changing land ecosystem processes}

In the future, many Arctic-boreal processes will respond sensitively to climate change, affecting ecosystem productivity and functions. These changes may lead to unprecedented consequences, e.g. in the magnitude of the ecosystem carbon sinks, production of aerosol precursor gases, and surface albedo. We need first to develop methods for identifying the land regions and processes that are especially sensitive to climate change. Only after that are we able to analyse their responses. 
Boreal forests are one of the largest terrestrial biomes, and account for around one-third of the Earth's forested area (Global Forest Watch, 2002; http://www.globalforestwatch. org/). Nearly $70 \%$ of all boreal forests are located in the Siberian region. The forest biomass, soils, and peatlands in the boreal forest zone together constitute one of the world's largest carbon reservoirs (Bolin et al., 2000; Kasischke, 2000; Schepaschenko et al., 2013). Due to their large forest surface areas and huge stocks of carbon $(\sim 320$ gigatonnes of carbon; GtC), the boreal and Arctic ecosystems are significant players in the global carbon budget. Furthermore, permafrost, a dominant feature of Siberian landscapes, stores around $1700 \mathrm{GtC}$ (Tarnocai et al., 2009). Boreal forests form the main vegetation zone in the catchment areas of large river systems, so they are an important part of the global waterenergy-carbon feedbacks.

The forest biomass forms a climate feedback via the anticipated changes in nutrient availability and temperatures, affecting carbon sequestered into both the aboveground biomass and soil compartment. The Siberian forests are currently assumed to be a carbon sink, although with a large uncertainty range of $0-1 \mathrm{PgC} \mathrm{yr}^{-1}$ (Gurney et al., 2002). However, these ecosystems are vulnerable to global climate change in many ways, and the effects on ecosystem properties and functioning are complicated. While higher ambient $\mathrm{CO}_{2}$ concentrations and longer growing seasons may increase plant growth and productivity, as well as the storage of carbon to soil organic matter (e.g. Ciais et al., 2005; Menzel et al., 2006), warming affects respiration and ecosystem water relations in the opposite way (Bauerle et al., 2012; Parmentier et al., 2011). Expected acceleration of fire regimes might also substantially impact the carbon balance in Arctic and boreal regions (Shvidenko and Schepaschenko, 2013).

One example of the potentially large feedbacks is the critical role that permafrost plays in supporting the larch forest ecotone in northern Siberia. The boreal forests in the high latitudes of Siberia are a vast, rather homogenous ecosystem dominated by larch. The total area of larch forests is around 260 million ha, or almost one-third of all forests in Russia. Larch forests survive in the semi-arid climate because of the unique symbiotic relationship they have with permafrost. The permafrost provides enough water to support larch domination, and the larch in turn blocks radiation, protecting the permafrost from intensive thawing during the summer season. The anticipated thawing of permafrost could decouple this relationship, and may cause a strong positive feedback, intensifying the warming substantially.

The ambient temperature, radiation intensity, vegetation type, and foliar area are the main constraints for the emission of biogenic volatile organic compounds (BVOCs) (Laothawornkitkul et al., 2009). This makes BVOC emissions sensitive to both climate and land use changes, via, e.g., increased ecosystem productivity or the expansion of forests into tundra regions. Although the inhibitory effect of $\mathrm{CO}_{2}$ on the process level may be important, Arctic greening may strongly enhance the production of BVOCs in northern ecosystems (Arneth et al., 2007; Sun et al., 2013). Open tundra may also act as a significant source for BVOCs, especially if the snow cover period changes (Aaltonen et al., 2012; Faubert et al., 2012). This would lead to negative climate feedbacks involving either aerosol-cloud or aerosol-carbon cycle interactions (M. Kulmala et al., 2013, 2014; Paasonen et al., 2013). Linear trends in the annual maximum normalized difference vegetation index (NDVI) over 15 years in the northern areas of the Yamalo-Nenets Autonomous Okrug region in Russia, provide supporting evidence of the increasing biological activity and greening, and the potential for enhanced BVOC emissions (Fig. 2).

In summary, even small proportional changes in ecosystem carbon uptake can switch terrestrial ecosystems from a net carbon sink to a carbon source, with consequent impacts on atmospheric $\mathrm{CO}_{2}$ concentrations and global temperatures (e.g. Bala et al., 2013; Bodman et al., 2013, Mukhortova et al., 2015). This process has already been observed, particularly in disturbed forests of northern Asia (Shvidenko and Schepaschenko, 2014). Currently, we do not fully understand all the factors influencing carbon storage, or the links between biogeochemical cycles of carbon, water, and nutrients in a changing climate. However, the changes in these processes may be large, and their impacts may either amplify or decrease climate change, especially in the high northern latitudes.

\subsubsection{Ecosystem structural changes and resilience}

The ecosystem structural changes are tightly connected to adaptation needs, and to the development of effective mitigation and adaptation strategies. Predictions concerning the shifting of vegetation zones are important for estimating the impacts of the region on future global GHG, BVOC, and aerosol budgets. Furthermore, natural and anthropogenic stresses, such as land use changes and biotic and abiotic disturbances, are shaping ecosystems in the Arctic and boreal regions and have many important feedbacks to climate (see, e.g., the review by Gauthier et al., 2015). In a warmer climate, northern ecosystems may become susceptible to insect outbreaks, drought, devastating forest fires, and other natural disasters. In addition, human impacts may cause sudden or gradual changes in ecosystem functioning. The ecosystem resilience is dependent on both the rate and magnitude of these changes. Recent studies have concluded that current estimates very likely overestimate the resilience of global forests and particularly boreal forests (Allen et al., 2015). In some cases, the changes may lead to system imbalance and possibly reaching a tipping point, after which the effects are irreversible. One of the most relevant research topics for the land system are to determine the structural changes and tipping points of the ecosystem changes in the northern panEurasian region. 


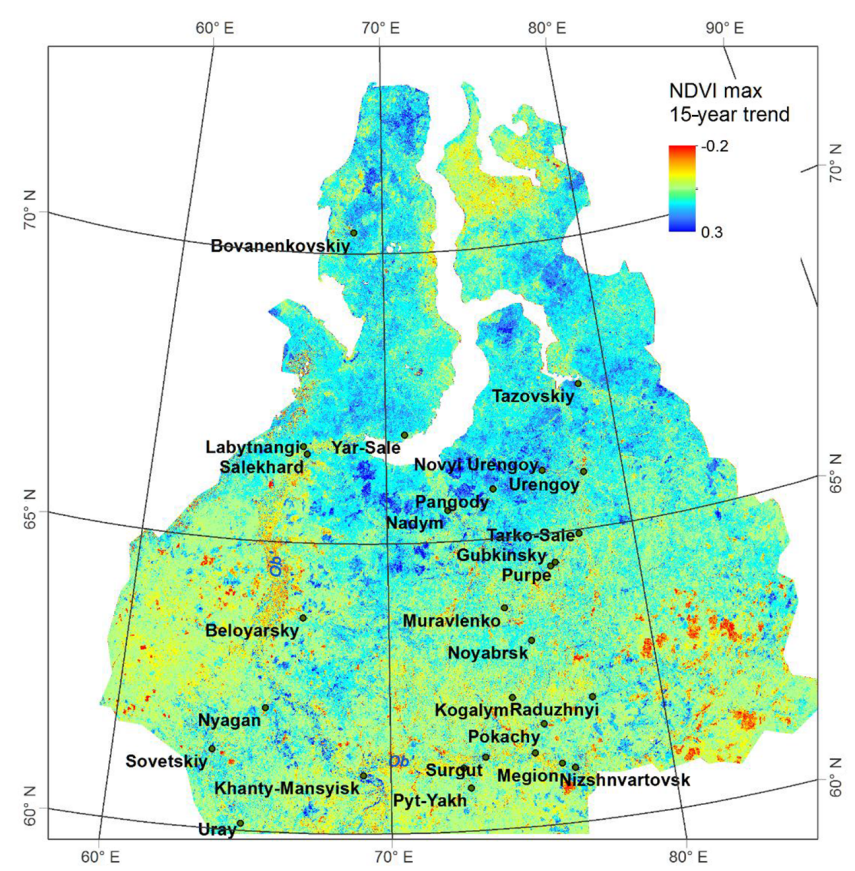

Figure 2. Linear trends in the annual maximum normalized difference vegetation index (NDVI) obtained from analysis of the MODIS $0.25 \mathrm{~km}$ data product for 2000-2014 over the north-western Siberia region in Russia. The trends are given in the NDVI changes per 15 years. The yellow colours show the decreasing NDVI, which corresponds to decreasing biological production; the blue colours show the increasing NDVI. More detailed analysis of the trends is given in Esau et al. (2016).

Part of the expected ecosystem structural changes is related to the lengthening of the growing season, which is taking place the Arctic-boreal regions due to climate change. This phenomenon, called "Arctic greening", is due to increased plant biomass growth and advancing tree lines, turning previously open tundra into shrubland or forest (Myneni et al., 1997; Xu et al., 2015). However, "browning" as a proxy of decreased productivity has also been observed during recent decades in many boreal regions (Lloyd and Bunn, 2007), including vast territories of central Siberia, together with a general downward trend in basal area increment after the mid-20th century (Berner et al., 2013) and the overall decline in green from 2011 to 2014 in Arctic regions (Phoenix and Bjerke, 2016). Current predictions on the extent and magnitude of these processes vary significantly (Tchebakova et al., 2009; Hickler et al., 2012; Shvidenko et al., 2013a, b). It has been estimated that the northward shift of bioclimatic zones in Siberia will be as large as $600 \mathrm{~km}$ by the end of this century (Tchebakova et al., 2009). By taking into account that the natural migration rate of boreal tree species cannot exceed 200-500 $\mathrm{m}$ per year, such a forecast implies major vegetation changes in huge areas. In addition, we need to have a deeper understanding of the future role of the browning process and to re-analyse the previous model predictions of arctic green- ing: to what extent are they wrong, and why (Phoenix and Bjerke, 2016)? This has important biophysical consequences and climatic feedbacks. Changes in vegetation cover can, e.g., lead to albedo changes and therefore higher net absorption of radiation in regions covered by forests compared to open vegetation (Jeong et al., 2011). This modifies the local heat and vapour fluxes, and affects boundary layer conditions as well as both local and larger-scale climate (Sellers et al., 1997).

Northern peatlands contain a significant part of the global soil organic matter reservoirs ( $45 \%$ of the world's soil carbon; Post et al., 1982), and comprise one of the world's largest GHG sources (in particular $\mathrm{CH}_{4}$ ) (IPCC, 2013). The hydrological conditions are a major factor in determining the functioning of peatlands as carbon source or sink, and the carbon balance of the vast northern peatlands is extremely sensitive to human influence, be it through either management or climate change. For example, thawing of permafrost peatlands in tundra regions might change tundra ecosystems from a stable state into a dynamically changing and alternating land-water mosaic, with dramatic impacts on their GHG production (Heikkinen et al., 2004; Repo et al., 2009). Today, peatland management activities range from drainage and peat harvesting to establishing crop plantations and forests. A complete understanding of the climatic effects of peatland management remains a challenging question (Maljanen et al., 2010).

Northern ecosystems are frequently suffering from increased stresses and deterioration. There is seldom a single and clear cause for forest dieback, but rather the ecosystems are suffering from multiple stresses simultaneously (e.g. Kurz et al., 2008a, b; Allen et al., 2010). This implies that a single stress factor may not be very dramatic for the resilience of the system, but when occurring simultaneously in combination with others, the system may cross a threshold (i.e. tipping point), and this may have dramatic consequences. Such perturbations and disturbances can include not only long-term pollutant exposures, but also stochastic events such as fires, flooding, windstorms, or insect population outbreaks, and human activities such as deforestation or the introduction of exotic plant or animal species. Disturbances of sufficient magnitude or duration can profoundly affect an ecosystem, and may force an ecosystem to reach a threshold beyond which a different regime of processes and structures predominates. Climate warming, precipitation changes during growth periods, and permafrost changes will substantially increase water stress, and consequently increase the risk of mortality for trees. This process has already clearly intensified over the entire circumpolar boreal belt (Allen et al., 2010). As a consequence, ecosystems may turn into carbon sources rather than sinks (Parmentier et al., 2011).

In the future, boreal forest diebacks may occur due to mass infections of invasive pathogens or herbivores, such as the autumnal moth (Epirrita autumnata) or mountain bark beetle (Dendroctonus ponderosae), which have previously been cli- 
matically controlled by harsh winter conditions. The growth and life cycles of herbivores or their habitat conditions may change in such a way that the outbreak frequencies and intensities of previously relatively harmless herbivore populations increase (Hunter et al., 2014). At the same time as climate is changing, boreal vegetation is also exposed to increased anthropogenic influences by pollutant deposition and land use changes (Dentener et al., 2006; Bobbink et al., 2010; Savva and Berninger, 2010). Large industrial complexes may lead to local forest diebacks, as has been observed in the Kola region (e.g. Nöjd and Kauppi, 1995; Tikkanen, 1995; Kukkola et al., 1997) and in some regions of Siberia (Baklanov et al., 2013). Societal transformations may lead to abandonment of agricultural land or deterioration of previously managed forests.

\subsubsection{Risk areas of permafrost thawing}

The major part of the northern Eurasian geographical region is covered by continuous permafrost. The fate of permafrost soils in high latitudes is important for global climate with regard to all greenhouse gases. Thawing of permafrost will also substantially alter the hydrological regimes, particularly in northern Asia, which will lead to increasing water stress in forests and explosive enlargement of fire extent and severity as well as post fire successions (Shvidenko et al., 2013b). These scenarios underline the urgent need for systematic permafrost monitoring, together with GHG measurements in various ecosystems. The treatment of permafrost conditions in climate models is still not fully developed (Bala et al., 2013). The major question is, how fast will the permafrost thaw proceed and how will it affect ecosystem processes and ecosystem-atmosphere feedbacks, including hydrology and greenhouse gas cycling.

Understanding of the feedbacks between carbon and water cycling, ecosystem functioning, and atmospheric composition related to permafrost thawing is one of the important topics of the land system study (Heimann and Reichstein, 2008; Schuur et al., 2009; Arneth et al., 2010). In high-latitude ecosystems with large, immobile carbon pools in peat and soil, the future net $\mathrm{CO}_{2}$ and $\mathrm{CH}_{4}$ exchange will depend on the extent of near-surface permafrost thawing, local thermal and hydrological regimes, and interactions with the nitrogen cycle (Tarnocai et al., 2009). The extra heat produced during microbial decomposition could accelerate the rate of change in active-layer depth, potentially triggering a sudden and rapid loss of carbon stored in carbon-rich Siberian Pleistocene loess (yedoma) soils (Khvorostyanov et al., 2008).

The connection between the climate and the thermal conditions in the subsurface layers (soil and bedrock) is an important aspect. The warming of the atmosphere will inevitably result in the warming of the permafrost layer, and is easily observed in deep borehole temperature data. However, the changes depend on the soil and rock type as well as on the pore filling fluids. As long as the pore fill is still ice, the climatic changes are reflected mainly in the thickness of the active layer, and in slow diffusive temperature changes of the permafrost layer itself. In areas where the ground is dominated by low ground temperatures and thick layers of porous soil types (e.g. sand, silt, peat), the latent heat of the porefilling ice will efficiently "buffer" and retard the final thawing. This is one of the reasons why relatively old permafrost exists at shallow depths in high-porosity soils. On the other hand, quite different conditions prevail in low-porosity areas, e.g. in crystalline rock areas.

The permafrost dynamics affect methane fluxes in many ways. Hot spots such as mud ponds emitting large amounts of $\mathrm{CH}_{4}$ may form when permafrost mires thaw. In contrast, lakes have occasionally disappeared as a result of the intensification of soil water percolation (Smith et al., 2005). The rapid loss of summer ice, together with increasing temperature and melting ice deposits, results in coastal erosion, physical destruction of the surface in hilly areas, activation of old carbon and elevated $\mathrm{CO}_{2}$ and $\mathrm{CH}_{4}$ emissions from seabottom sediments (Vonk et al., 2012). High methane emissions have been observed from the East Siberian Arctic Shelf (Shakhova et al., 2010).

\subsection{Atmospheric system - state-of-the-art and future research needs}

\subsubsection{Atmospheric composition and chemistry}

Atmospheric composition plays a central role in the northern Eurasian climate system. In addition to greenhouse gases and their biogeochemical cycling discussed in more detail in Sect. 3.2, key compounds in this regard are ozone and other oxidants, carbon monoxide, numerous organic compounds as well as different types of aerosols and their precursors $\left(\mathrm{SO}_{2}\right.$ will be discussed in Sect. 3.5). At the moment, there is a serious gap in our knowledge on tropospheric composition and chemistry over Russia and China, with particularly few observation programs being active over Siberia (Crutzen et al., 1998; Ramonet et al., 2002; Paris et al., 2008; Kozlova et al., 2008; Uttal et al., 2015, Paris et al., 2010a, b; Sasakawa et al., 2010; Chi et al., 2013; Saeki et al., 2013; Ding et al., 2013a, b; Berchet et al., 2015; Heimann et al., 2014).

There is thus an urgent need for harmonized, coordinated and comprehensive greenhouse gas, trace gas, and aerosol in situ observations over northern Eurasia and China (longterm transport aspect) comparable to European and circumpolar data observations. In Fig. 3 we illustrate the geographical coverage of the ground stations that will be part of the coordinated, coherent, and hierarchic observation network in the northern Eurasian region and in China.

\section{Main pollutants}

Little is known about whether and how the regional ozone budget in northern pan-Eurasia differs from that in the rest of 


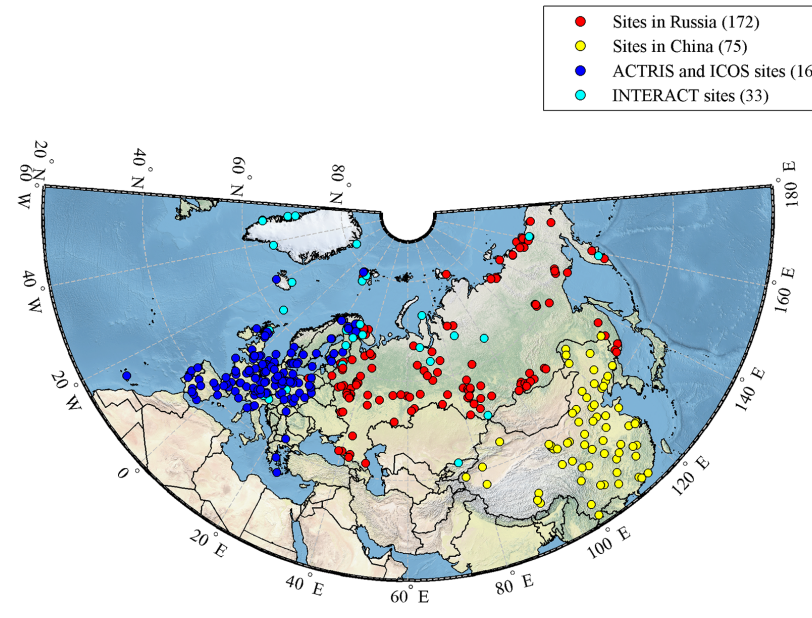

Figure 3. Map showing the existing ACTRIS (aerosols, clouds, and trace gases research infrastructure network) and ICOS (Integrated Carbon Observations System) stations in Europe (blue), stations making atmospheric and/or ecosystem measurements in Russia (red), INTERACT (International Network for Terrestrial Research and Monitoring in the Arctic) stations in Russia (light blue), and China Flux stations in China (yellow). However, all of these stations need certain upgrades.

the Northern Hemisphere (Ding et al., 2008; Berchet et al., 2013). Arctic tropospheric ozone is significantly influenced by long-range import of ozone and precursors from midlatitude sources as well as by boreal wildfires (Ding et al., 2009; Wespes et al., 2012; Paris et al., 2010b; Vivchar et al., 2009). The role of biomass burning emissions in the ozone budget in high latitudes remains controversial. While most studies suggest significant ozone production in boreal smoke plumes (e.g. Paris et al., 2010b; Parrington et al., 2013; Jolleys et al., 2015), some observations from individual plumes suggest that $\mathrm{O}_{3}$ production in boreal wildfire plumes may be weaker, or even turn into net destruction, compared to fire plumes at lower latitudes (Liang et al., 2011; Jaffe and Wigder, 2012). Recent modelling work has suggested that boreal fires produce a substantial large-scale enhancement in summertime ozone at high latitudes, which appears to be highly sensitive to differences in partitioning of reactive nitrogen among models (Arnold et al., 2015). The boreal biosphere, on the other hand, provides a large sink for tropospheric ozone (Paris et al., 2010b; Parrington et al., 2013). Given their importance for air quality and global greenhouse gas budget, more atmospheric measurements of $\mathrm{O}_{3}$, its precursors and other pollutants over Siberia are needed (see Elansky et al., 2012). This is particularly the case in light of increasing local Arctic sources of ozone precursors $\left(\mathrm{NO}_{x}\right.$, VOCs, volatile organic compounds) from, e.g., shipping and fossil fuel resource extraction (Roiger et al., 2015). Such data sets would be particularly useful for the evaluation of atmospheric chemistry models and satellite products.
The changes in the abundance of anthropogenic aerosols and their precursors in northern Eurasia have been extensive during the last decades (Granier et al., 2011), and this has almost certainly contributed to the very different regional warming patterns over these areas (e.g. Shindell and Faluvegi, 2009). The main anthropogenic aerosols in this context are primary carbonaceous particles, consisting of organic and black carbon as well as secondary sulfate particles produced during the atmospheric transport of sulfur dioxide. These species, as well as nitrate, have also been found to dominate the aerosol composition at the Zotino Tall Tower Observation Facility (ZOTTO) site in central Siberia (Mikhailov et al., 2015a, b; Ryshkevich et al., 2015). These aerosols cause large perturbations to the regional radiation budget downwind of major source areas in the northern Eurasian region, and the resulting changes in cloud properties and atmospheric circulation patterns may be important even far away from these sources (Koch and Del Genio, 2010; Persad et al., 2012). In the snow-covered parts of Eurasia, long-range transported aerosols containing black carbon and deposited onto snow tend to enhance the spring and early-summer melting of the snow, with concomitant warming over this region (Flanner et al., 2009; Goldenson et al., 2012; Meinander et al., 2013; Atlaskina et al., 2015).

The most important natural aerosol type over large parts of Eurasia is secondary organic aerosol originating from atmospheric oxidation of BVOCs emitted by boreal forests and possibly other ecosystems. Studies conducted in the Scandinavian part of the boreal zone indicate that new particle formation associated with BVOC emissions is the dominant source of aerosol particles and cloud condensation nuclei during summer time (Mäkelä et al., 1997; Kulmala et al., 2001; Tunved et al., 2006; Asmi et al., 2011; Hirsikko et al., 2011). The production of secondary organic aerosols associated with BVOC emissions has been estimated to induce large direct and indirect radiative effects over the boreal forest zone (Spracklen et al., 2008; Tunved et al., 2006; Lihavainen et al., 2009, 2015; Scott et al., 2014). The few continuous measurement data sets from Siberia suggest similarities in the frequency and seasonal pattern of new particle formation events between Siberia and Nordic stations (Dal Maso et al., 2007; Arshinov et al., 2012; Asmi et al., 2016). Measurements conducted at the ZOTTO site in central Siberia have shown that biogenic secondary organic aerosols reach high concentrations in summer and dominate the aerosol composition during this season (Mikhailov et al., 2015a, b; Ryshkevich et al., 2015). At this site, however, new particle formation events are seen much less frequently than at the Nordic stations (Heintzenberg et al., 2011). At present, relatively little is known about the overall contribution of biogenic emissions to aerosol number or mass concentrations, or to the cloud condensation nuclei budget, in northern Eurasia.

Other important natural aerosol types in northern Eurasia are sea spray, mineral dust, and primary biogenic aerosol particles. Sea spray aerosol makes an important contribution to 
the atmospheric aerosol over the Arctic Ocean and its coastal areas (Zábori et al., 2012, 2013), and influences cloud properties over these regions (Tjernström et al., 2014). The climatic effects of sea spray are expected to change in the future as a result of changes in the sea ice cover and ocean temperatures (Struthers et al., 2011). Mineral dust particles affect regional climate and air quality over large regions in Asia, especially during periods of high winds and moderate precipitation. Mineral dust and primary biological aerosol particles (PBAPs) particles are also effective ice nuclei (Hoose and Möhler, 2012), and have the potential to influence radiative and other properties of mixed-phase cold clouds in the Arctic-boreal regions. Over northern Eurasia, PBAPs typically contribute more than $20 \%$ of $\mathrm{PM}_{2.5}$ (fine particulate matter with a diameter of $2.5 \mu \mathrm{m}$ or less) organic aerosol mass concentrations (Heald and Spracklen, 2009) and $25 \%$ of supermicron aerosol number concentrations (Spracklen and Heald, 2014). Ice nucleation, in general, is one of the key microphysical processes in the atmosphere that remain ill understood. However, a novel theoretical approach (Laaksonen, 2015; Laaksonen and Malila, 2016) has been shown to be superior to older theories in the case of water nucleation on solid surfaces, and it may open a completely new avenue in the studies of atmospheric ice formation.

Satellites provide information about spatial distributions of the column-integrated concentrations of aerosols (Andreae, 2009) and various trace gases including ozone and its precursors (Burrows et al., 2011). These atmospheric constituents are generally retrieved using passive instruments, which have good sensitivity near the surface. However, retrieving information on the near-surface concentrations of pollutants requires assumptions on their vertical distributions. For instance, the retrieval of tropospheric ozone from satellite observations requires corrections for the high concentrations in the upper troposphere and lower stratosphere. For aerosols, which can only be retrieved in clear-sky conditions, the situation may be complicated when disconnected layers are present with different types of aerosols. A solution may be the retrieval of aerosol vertical variation or the height of the aerosol layer using, e.g., active instruments (lidars), or retrieval using spectrally resolved observations in the oxygen A-band (e.g. Hollstein and Fisher, 2014), or instruments providing multiple viewing algorithms such as MISR (Nelson et al., 2013) or AATSR (Virtanen et al., 2014). Another complication for aerosols may be the vertical variation of the physical and chemical properties, which renders it difficult to obtain closure between column and groundbased in situ measurements (Zieger et al., 2015, and references cited therein). Nevertheless, good progress has been made in aerosol retrieval, and column-integrated aerosol measurements (aerosol optical depth, AOD) from satellites and ground-based observations compare favourably (e.g. de Leeuw et al., 2015; Kolmonen et al., 2015). Measurements of trace gases from space using wavelengths in the thermal infrared suffer from low sensitivity in the lower troposphere
(Pommier et al., 2010). All these factors may render the comparison against local ground-based in situ observations difficult, although a possible way out could be the use of chemical transport models constrained by the satellite column measurements (e.g. de Laat et al., 2009; Stavrakou et al., 2012, 2014), possibly together with sub-orbital airborne measurements of relevant species. Satellite-measured AOD has been successfully applied to obtain information on ground-based aerosol mass concentrations $\left(\mathrm{PM}_{2.5}\right)$ (Xu et al., 2015; van Donkelaar et al., 2015). In addition, the use of multiple satellite instruments, with different characteristics, is proposed to obtain more accurate information on the transport of aerosols and trace gases and their vertical distribution (e.g. Naeger et al., 2016). Recently, a technique has been demonstrated that makes it possible to derive $\mathrm{CCN}$ (cloud condensation nuclei) concentrations at cloud base using remote sensing of cloud properties (Rosenfeld et al., 2016).

\section{Large-scale pollutant transport and sources}

Of particular interest is the pollutant transport to Arctic areas, where they can influence the radiation budget and climate in various ways (Stohl, 2006; Warneke et al., 2009; Meinander et al., 2013; Eckhardt et al., 2015). Model simulations suggest that European emissions dominate Arctic pollutant burdens near the surface, with sources from North America and Asia more important in the mid- and upper troposphere (Monks et al., 2015). The impact and influence of China and its polluted megacities on Arctic and boreal areas is a topic of key importance, given recent and rapid Chinese industrialization. Inter-continental pollution transport has also become of increased concern due to its potential influence on regional air quality. The pollutant export from North America and Asia has been characterized by intensive field campaigns (Fehsenfeld et al., 2006; Singh et al., 2006), but long-term research approaches are lacking.

Emissions from forest fires (van der Werf et al., 2006; Sofiev et al., 2013) and from agricultural fires in southern Siberia, Kazakhstan, and Ukraine (Korontzi et al., 2006) in spring and summer are large sources of trace gases such as carbon monoxide (Nédélec et al., 2005; Konovalov et al., 2014) as well as aerosol particles (Konovalov et al., 2015). Aerosols emitted by forest fires are of particular interest, since the strength of this source type depends on both climate change and human behaviour (Pechony and Shindell, 2010), and since particles emitted by these fires have potentially large radiative effects over Eurasia (Randerson et al., 2006). We need comprehensive top-down emissions estimates, using inverse modelling constrained by satellite observations, in order to provide quantitative information on the source strength of aerosols and trace gases emitted by open fires.

Air pollution in monsoon Asia has two main characteristics. First, the total pollutant emission rate from fossil fuel combustion sources is very high, leading to a high concentra- 
tion of primary and secondary pollutants in Asia, especially in eastern China and northern India. Observations show that Asia is the only region where the concentrations of key pollutants, such as nitrogen oxides (Richter et al., 2005; Mijling et al., 2013) and their end-product ozone (Ding et al., 2008; Wang et al., 2009; Verstraeten et al., 2015), are still increasing. Second, in addition to the anthropogenic fossil fuel combustion pollutants, monsoon Asia is also influenced by intensive pollution from seasonal biomass burning and dust storms. For example, intensive forest burning activities often take place in south Asia during spring and in Siberia during summer, whereas intensive anthropogenic burning of agricultural straw takes place in the north and east China plains. Dust storms frequently occur in the Taklimakan and Gobi deserts in north-west China, and this dust is often transported over eastern China, southern China, the Pacific Ocean and even the entire globe (Nie et al., 2014). After mixing with other anthropogenic pollutants, biomass burning and mineral dust aerosols have been found to cause complex interactions in the climate system (Ding et al., 2013a; Nie et al., 2014).

\subsubsection{Urban air quality}

The northern Eurasian urban environments are characterized by cities with strong anthropogenic emissions from local industry, traffic, and housing in Russia and China, and by megacity regions with alarming air quality levels like those of Moscow and Beijing. Bad air quality has serious health effects and damages ecosystems. In Beijing, for example, concentrations of atmospheric fine particles have been found to be more than 10 times higher than the safe level recommended by the World Health Organization (WHO) (Zheng et al., 2015). Furthermore, atmospheric pollutants and oxidants play a central role in climate change dynamics via their direct and indirect effects on global albedo and radiative transfer. A deeper understanding of the unpredicted chemical reactions between pollutants and identification of the most relevant feedbacks between air quality and climate at northern high latitudes and in China is the most urgent task helping us to find practical solutions for more healthy air (Kulmala, 2015).

In Siberian cities, the air quality is strongly linked to climatic conditions typical for Siberia. Stable atmospheric stratification and temperature inversions are predominant weather patterns for more than half of the year. This contributes to the accumulation of different pollutants in the lowest layers of the atmosphere, thus increasing their impact on ecosystems and humans. In addition to the severe climatic conditions, human impacts on the environment in industrial areas and large cities continue to increase. In winter time, shallow and stably stratified planetary boundary layers (PBL) typical for northern Scandinavia and Siberia are especially sensitive to even weak impacts and, therefore, deserve particular attention, especially in the conditions of environmental and climate change (Zilitinkevich and Esau, 2009; Esau et al., 2012; Davy and Esau, 2014; Wolf et al., 2014; Wolf and Esau, 2014). Unstably stratified PBLs interact with the free atmosphere mainly through turbulent ventilation at the PBL upper boundary (Zilitinkevich, 2012). This mechanism, still insufficiently understood and poorly modelled, controls the development of convective clouds, as well as dispersion and deposition of aerosols and gases, which are essential features of heat waves and other extreme weather events.

The worst air pollution episodes are usually associated with stagnant weather conditions with a shallow PBL, which promotes the accumulation of intensively emitted pollutants near the surface. The lower PBL is also influenced by the heavy pollution itself through its direct or indirect effects on solar radiation and hence the surface sensible heat flux (e.g. Ding et al., 2013b). The boundary layer-air pollution feedback will decrease the height of the PBL and result in an even more polluted PBL (Ding et al., 2013b; Wang et al., 2014; Petäjä et al., 2016). Therefore, considering the complex land-surface types (city clusters surrounded by agricultural areas) and pollution sources, improving our understanding of the associated feedbacks is very important for forecasting extreme air pollution episodes and for long-term policymaking. In order to understand this topic, more vertical measurements using aircraft, balloons, and remote sensing techniques, as well as advanced numerical models including all relevant processes and their couplings, are needed.

Planetary boundary layers are subject to diurnal variations, absorb surface emissions, control microclimate, air pollution, extreme colds, and heat waves, and are sensitive to human impacts. Very stable stratification in the atmosphere above the PBL prevents the compounds produced by the surface fluxes or surface emissions from efficiently penetrating from the PBL into the free atmosphere. This means that the PBL height and turbulent fluxes through the PBL upper boundary control local features of climate and extreme weather events, such as the heat waves associated with convection, or the strongly stable stratification events triggering the air pollution (Zilitinkevich et al., 2015). This concept (equally relevant to the hydrosphere) illustrates the importance of modelling and monitoring the atmospheric PBL height, which varies from dozens to thousands of metres (Zilitinkevich, 1991; Zilitinkevich et al., 2007; Zilitinkevich and Esau, 2009). To carry out a comprehensive inventory of the PBL height over northern Eurasia is urgently needed.

\subsubsection{Atmospheric circulation and weather}

The ongoing environmental change and its amplification in northern Eurasia pose special challenges to the prediction of weather-related hazards, and also to long-term impacts. A key question is how the atmospheric dynamics (synoptic scale weather, boundary layer characteristics) will change in Arctic and boreal regions. The recent changes in the Arctic sea ice have been much more rapid than models and scientists anticipated about 10 years ago. The role of the Arctic Ocean 
in the climate system and sea ice changes have affected midlatitude weather and climate, with central and eastern Eurasia among the regions with strongest effects (Vihma, 2014; Overland et al., 2015) (see Sect. 2.3.1).

\section{Atmospheric dynamics}

The reliability of weather forecasts, and the extension of the time range of useful forecasts is needed for minimizing economic and human losses from extreme weather and extreme weather-related natural hazards. In Europe, this range is currently on average about 8-9 days (Bauer et al., 2015), which allows reliable early warnings to be issued for weatherrelated hazards, such as windstorms and extreme precipitation events with flash floods. The time range of useful forecasts has typically increased by a day per decade over the past three decades (Uppala et al., 2005). In the northern Eurasian region, improved predictions can be used, for instance, for better prediction of thermal comfort conditions in northern cities (Konstantinov et al., 2014). A strong urban heat island effect has already been observed in urban areas of the Arctic with complex spatial and temporal structures (Konstantinov et al., 2015).

Understanding of PBL processes is particularly important for improving the weather predictions. The representation of boundary layer clouds, and their further coupling to convection in stable conditions is not currently well understood. Quantification of the behaviour of the PBL over the northern Eurasian region is needed in analyses of spatial and temporal distribution of the surface fluxes, in predictions of microclimate and extreme weather events, and in modelling clouds and air quality.

The development of diagnostic and modelling methods for aero-electric structures is important for a study of both convective and electric processes in the lower troposphere (Shatalina et al., 2005, 2007). Convection in the PBL leads to the formation of aero-electric structures, manifested in ground-based measurements as short-period electric-field pulsations with periods from several seconds to several hundreds of seconds (Anisimov et al., 1999, 2002). The sizes of such structures are determined by the characteristic variation scales of aerodynamic and electrodynamics parameters of the atmosphere, including the PBL and surface-layer height as well as by the inhomogeneities in the ground (water) surface. Formed as a result of convective processes and the capture of positive and negative charged particles (both ions and aerosols) by convective elements (cells), aero-electric structures move with the airflow along the Earth's surface. The further evolution of convective cells results, in particular, in cloud formation.

\section{Global electric circuit}

The global electric circuit (GEC) is an important factor connecting the solar activity and upper atmospheric processes with the Earth's environment, including the biosphere and climate (Dolezalek et al., 1976; Singh et al., 2004). Thunderstorm activity maintains this circuit, whose appearance is dependent on atmospheric conductance variations over a wide altitude range. The anthropogenic impact on the GEC through aviation, forest fires, and electromagnetic pollution has been noted with great concern, and the importance of lightning activity in climate processes has been recognized. The GEC forms for two reasons: the continuous operation of ionization sources, which provides an exponential growth of the conductivity in the lower atmosphere, and the continuous operation of thunderstorm generators, providing a high rate of electrical energy generation and dissipation in the troposphere. Therefore, the GEC is influenced by both geophysical and meteorological factors, and can serve as a convenient framework for the analysis of possible inter-connections between atmospheric electrical phenomena and climate processes. Further exploration of the GEC as part of the climate system studies, specifically its effect on the balance between the Earth's ionosphere and global circuit, requires accurate modelling of the GEC stationary state and its dynamics (Mareev, 2010). Special attention should be paid to the observations and modelling of generators (thunderstorms, electrified shower clouds, mesoscale convective systems) in the global circuit.

\subsection{Aquatic system - state of the art and future research needs}

\subsubsection{The Arctic Ocean in the climate system}

The essential processes related to the interaction between the Arctic ocean and other components of the Earth system include the air-sea exchange of momentum, heat, and matter (e.g. moisture, aerosol, trace gases, $\mathrm{CO}_{2}$, and $\mathrm{CH}_{4}$ ) as well as the dynamics and thermodynamics of sea ice. The most dramatic change in the Arctic Ocean has been the rapid decline of the sea ice cover. Since the early the 1980s, the Arctic sea ice extent has decreased by roughly $50 \%$ in summer and autumn (Cavalieri and Parkinson, 2012), while the winter sea ice thickness in the central Arctic has decreased by approximately 50\% (Kwok and Rothrock, 2009). Arctic sea ice changes have serious teleconnections. Despite the warming climate, wintertime cold spells in East Asia have become more frequent, stronger and longer lasting in this century compared with the 1990s (Kim et al., 2014). It also seems that the strong decline of the Arctic sea ice has favoured atmospheric pressure patterns that generate cold-air outbreaks from the Arctic to East Asia (Mori et al., 2014; Kug et al., 2015; Overland et al., 2015). The reasons for and the future evolution of the sea ice decline, as well as its effects on the ocean, atmosphere and surrounding continents are among the current topics of study on the Arctic climate system. Other major issues include the role of the ocean in the Arctic amplification of climate change, greenhouse gas exchange be- 
tween the ocean, sea ice, and atmosphere as well as aerosol budgets in the marine Arctic (Smedsrud et al., 2013). The key question here is related to the changes of sea ice extent and thickness, and to the terrestrial snow cover change.

Many of the processes considered to be responsible for the Arctic amplification of climate warming are related to the ocean and sea ice (Döscher et al., 2014). Among these, the snow-/ice-albedo feedback has received the most attention (e.g. Flanner et al., 2011). This feedback is strongest when sea ice is replaced by open water, but it starts to play a significant role already in spring when the snowmelt on top of sea ice begins. This is because of the large albedo difference between dry snow (albedo about 0.85 ) and wet, melting, bare ice (albedo about 0.40 ). More work is needed to understand quantitatively the reduction of snow/ice albedo during the melting season, including the effects of melt ponds and pollutants in the snow. Other amplification mechanisms related to the ocean include increased heat transports from lower latitudes to the Arctic (Polyakov et al., 2010; Döscher et al., 2014) and fall-winter energy loss from the ocean (Screen and Simmonds, 2010). Furthermore, the melting of sea ice strongly affects evaporation, and hence the water vapour and cloud radiative feedbacks (Sedlar et al., 2011), and the PBL thickness, which controls the sensitivity of the air temperature to heat input into the PBL (Esau et al., 2012; Davy and Esau, 2016). The relative importance of the mechanisms affecting the Arctic amplification of climate warming are not yet well known (see also Pithan and Mauritsen, 2014; Cohen et al., 2014).

The rapid decline of the Arctic sea ice cover has tremendous effects on navigation and exploration of natural resources. To be able to predict the future evolution of the sea ice cover, the first priority is to better understand the reasons, including the role of black carbon (see Bond et al., 2013), behind the past and ongoing sea ice evolution. Several processes have contributed to the decline of Arctic sea ice cover, but the role of these processes needs better quantification (Smedsrud et al., 2013; Vihma et al., 2014). Further studies are needed on the impacts of changes in cloud cover and radiative forcing (Kay et al., 2008), atmospheric heat transport (Kapsch et al., 2013) and oceanic heat transport (Döscher et al., 2014). In addition, as the ice thickness has decreased, the sea ice cover becomes increasingly sensitive to the icealbedo feedback (Perovich et al., 2008). Other issues calling for more attention include the reasons for the earlier onset of the spring melt (Maksimovich and Vihma, 2012), changes in the phase of precipitation (Screen and Simmonds, 2012), and large-scale interaction between the sea ice extent, sea surface temperature distribution, and atmospheric dynamics (cyclogenesis, cyclolysis, and cyclone tracks) as discussed, e.g. by Outten et al. (2013).

In addition to thermodynamic processes, another factor affecting the sea ice cover in the Arctic is the drift of sea ice. The momentum flux from the atmosphere to the ice is the main driver of sea-ice drift, which is poorly represented in climate models (Rampal et al., 2011). This currently hinders a realistic representation of sea-ice drift patterns in largescale climate models. Furthermore, the progressively thinning ice pack is becoming increasingly sensitive to wind forcing (Vihma et al., 2012). In the future, research has to address the main processes that determine the momentum transfer from the atmosphere to the sea ice, including the effects of atmospheric stratification and sea ice roughness.

To understand better the links between the Arctic Ocean and terrestrial Eurasia, there is a particular need to study the effects of Arctic sea ice decline on Eurasian weather and climate (Sect. 2.2.3) Another poorly studied problem related to the Arctic Ocean is the role of sea ice as a source of aerosol precursors, and in the gas exchange between the ocean and atmosphere (Parmentier et al., 2013). Preliminary results of field studies at the drifting stations North Pole 35 and 36 (Makshtas et al., 2011) showed that the shrinking sea ice cover could be the reason for increasing $\mathrm{CO}_{2}$ uptake from the atmosphere over the annual cycle, and for the growth of the seasonal amplitude of $\mathrm{CO}_{2}$ concentrations in the Arctic.

Climate models project that air temperatures and precipitation will increase over the Arctic Ocean, and that this may have important effects on the structure of sea ice. Increased snow load on a thinner ice may in the future cause flooding of seawater on ice in the Arctic, which results in the formation of snow ice. Increased snowmelt and rain, on the other hand, results in increased percolation of water to the snowice interface, where it re-freezes, forming super-imposed ice (Cheng et al., 2008). Snow ice and super-imposed ice have granular structures, and differ thermodynamically and mechanically from the sea ice that currently prevails in the Arctic.

The changes in the Arctic Ocean have opened some, albeit limited, possibilities for seasonal prediction. These are mostly related to the large heat capacity of the ocean: if there is little sea ice in the late summer and early autumn, this tends to cause large heat and moisture fluxes to the atmosphere, favouring warm, cloudy weather in late autumn and early winter (Liu et al., 2011; Stroeve et al., 2012). On the other hand, the reduction of the sea ice thickness may decrease the possibilities for seasonal forecasting of ice conditions in the most favourable navigation season in late summer-early autumn. This is because a thin ice is very sensitive to unpredictable anomalies in the atmospheric forcing. For example, in August 2012 a single storm caused a reduction of the sea ice extent by approximately 1 million $\mathrm{km}^{2}$. The reduced sea ice extent in the winter months has significant impacts on convective clouds. Observations revealed a gradually increasing frequency of the convective cloud fields over Norwegian and Barents seas (Chernokulsky and Mokhov, 2012; Esau and Chernokulsky, 2015). The unusually strong atmospheric convection and weaker virtual potential temperature inversions create favourable conditions for the extreme Arctic cold outbreaks and meso-scale cyclones known as polar lows (Kolstad et al., 2009). 
It is vital to enhance routine observations, data assimilation techniques and prediction models in order to properly monitor the physical state of the environment. Longer-term impacts of the reduced ice cover are largely unknown, because the scientific community has had only little time to create new knowledge on essential climate variables across the domain (see Sect. 2.3.1). To improve preparedness, new observational evidence is therefore needed to reduce uncertainties in the system dynamics both on short and longer timescales.

\subsubsection{Arctic marine ecosystem}

The ice cover of the Arctic Ocean is undergoing fast changes, including a decline of summer ice extent and ice thickness (see Sect. 2.3.1). This results in a significant increase of the ice-free sea surface in the vegetation season, and an increase in the duration of the growing season itself. The key topic of future research is the joint effect of Arctic warming, ocean freshening, pollution load, and acidification on the Arctic marine ecosystem, primary production, and carbon cycle.

New ice-free areas of the Arctic Ocean could result in a pronounced growth of the annual gross primary production (GPP), increased phytoplankton biomass, and a loss of icerich algae communities associated with the low ice sheet surface (Bluhm et al., 2011). Progressive increase of oil and natural gas drilling and transportation over the shelf areas will be escalating the environmental changes of the Arctic marine ecosystems. Furthermore, there is a risk of irreversible changes in marine Arctic productivity and key biogeochemical cycles, and the potential for $\mathrm{CO}_{2}$ absorption by marine ecosystem. Processes involving the Arctic may also affect adjacent boreal areas.

We do not know how the climatically induced increase in GPP and phytoplankton biomass will influence the productivity of higher trophic levels of the Arctic ecosystem. In typical Arctic ecosystems, the most important consumers are large-sized herbivorous copepods, which have life cycles synchronized with the temperature as well as the seasonal algae dynamics (Kosobokova, 2012). Another important consumer community are the small-sized herbivorous copepods, which are important especially in shelf ecosystems. An increase in the phytoplankton production in fall, together with an increase in the sea temperature, may influence the populations of small-sized copepods, and increase their role in mass and energy flow in the ecosystems. Our current understanding of the role of small copepods in the Arctic ecosystems is limited (Arashkevich et al., 2010). An increase in surface water temperature may "open the Arctic doors" for new species, and change the Arctic pelagic food webs, energy flows, and biodiversity.

Increases in the Arctic sea temperature may lead to populations from neighbouring regions penetrating the Arctic ecosystem, changing the structure and functioning of native ecosystems. For example, a $1.5^{\circ} \mathrm{C}$ water temperature in- crease in the Bering Sea during the mid-1970s allowed the Alaskan Pollock to penetrate the Arctic ecosystem, and occupy a place as a keystone species for several years, supporting one of the world's largest regional fish harvests (Shuntov et al., 2007). The Bering Sea ecosystem is very rich compared to the Arctic ecosystems. Currently, we are not aware of food sources sufficient for supporting massive invader populations even in case of climate-induced changes in ecosystems. However, the appearance of aggressive new species even in low numbers may dramatically impact the sensitive Arctic ecosystems and have effects on the future regulation of international fisheries in the Arctic.

We have only recently begun to understand the processes that regulate freshwater-marine ecosystem interactions in estuarine zones (Flint, 2010). The mechanisms determining the impact of riverine waters over the Arctic shelves and the central deep basin, and their dependence on specific climatic forces, are still poorly understood. In order to determine the impact of riverine waters, it is important to locate new flagship stations or permanent observation points in the estuaries of large Siberian rivers. The changing riverine discharge to the Arctic shelves may amplify the impact of climate warming on the Arctic marine ecosystems. Degradation of permafrost, soil erosion, changes in snow cover and summer precipitation may all lead to changes in flood timing, and also to an increase in the amount of fresh water and materials of terrestrial origin, including organic matter and nutrients, annually delivered to the Arctic shelves, and further to the Arctic basin (Gustafsson et al., 2011). Human-driven land use changes to drainage basins and associated river systems have the potential to increase the speed of delivery of pollutants to the Arctic sea.

\subsubsection{Lakes, wetlands, and large-scale river systems}

In the last decade, the combined effects of air pollution and climate warming on fresh-water systems have received increasing attention (Skjelkvåle and Wright, 1998; Schindler, 2001; Alcamo et al., 2002; Sanderson et al., 2006; Feuchtmayr et al., 2009; Sereda et al., 2011). It is important to understand the future role of Arctic-boreal lakes, wetlands, and large river systems, including thermokarst lakes and running waters of all size, in biogeochemical cycles, and how these changes affect livelihoods, agriculture, forestry, and industry. The water chemistry of lakes without any direct pollution sources in the catchment area can be expected to reflect regional characteristics of water chemistry, as well as global anthropogenic processes, such as climate change and long-range air pollution (Müller et al., 1998; Moiseenko et al., 2001; Battarbee et al., 2005). The current ground-based streamflow-gauging network over the northern Eurasian region does not provide adequate spatial coverage for many scientific and water management applications, including the verification of the land-surface run-off contribution to the recipients of intra-continental run-off. Special field labo- 
ratories, with joint observation and modelling capabilities in hydrometeorology, sedimentology, and geochemistry are needed to understand the spreading of tracers and pollutants as part of current and future global environmental fluxes.

The gradient in water chemistry from the tundra to the steppe zones in Siberia can provide insight into the potential effects of climate change on water chemistry. In the last century, long-range trans-boundary air pollution led to changes in the geochemical cycles of sulfur, nitrogen, metals, and other compounds in many parts of the world (Schlesinger, 1997; Vitousek et al., 1997a, b; Kvaeven et al., 2001; Skjelkvåle et al., 2001). Environmental pollution problems also include the waterborne spreading of nutrients and pesticides from local agricultural areas, heavy metals often originating from mining areas, and other elements and chemicals, such as persistent organic pollutants from urban and industrial areas. Shifts in downstream loads cause changes in river and delta dynamics. One example of important study area is the Selenga River basin, which is located in the centre of Eurasia, extends from northern Mongolia into southern Siberia (Russia), and has its outlet at Lake Baikal. The Selenga River basin and Lake Baikal are located in the upstream part of the Yenisei River system, which discharges into the Arctic Ocean. Lake Baikal has the largest lake volume in the world at about $23000 \mathrm{~km}^{3}$ (comprising $20 \%$ of all unfrozen freshwater in the world), hosts a unique ecosystem (Granina, 1997), and is an important regional water resource (Garmaev and Khristoforov, 2010; Brunello et al., 2006). There are numerous industries and agricultural activities within the Selenga River basin, which affect the water quality of the lake and its tributaries. Mining is well-developed in the region (e.g. Karpoff and Roscoe, 2005; Byambaa and Todo, 2011), and heavy metals accumulate in biota and in sediments of the Selenga River delta and Lake Baikal (Boyle et al., 1998; Rudneva et al., 2005; Khazheeva et al., 2008).

In addition to water chemistry, the role of aquatic systems as a net sink or source for atmospheric $\mathrm{CO}_{2}$ is presently under debate. When precipitation or other processes transport large volumes of organic matter from land into nearby lakes and streams, the carbon of this matter effectively disappears from the carbon budget of the terrestrial ecosystem (Huotari et al., 2011). The enhanced decomposition of soil organic matter may significantly affect the transport of terrestrial carbon to rivers, estuaries, and the coastal ocean. The contribution of this process to the global and regional carbon budgets is unknown. Thus, the biological processes taking place in the terrestrial ecosystem (e.g. photosynthesis, respiration, and decomposition) and in the aquatic ecosystem are interlinked. The observed higher temperature response of aquatic ecosystems compared to terrestrial ecosystems indicates that a substantial part of the carbon respired or emitted from the aquatic system must be of terrestrial origin (Yvon-Durocher et al., 2012). Long-term measurements carried out during all seasons in the littoral zone of Lake Baikal showed that maximum $\mathrm{CO}_{2}$ sink and emission rates are observed in August and December (during the pre-ice period), respectively, and the total $\mathrm{CO}_{2}$ flux from the atmosphere into the littoral zone of Lake Baikal was estimated to be $3-5 \mathrm{~g} \mathrm{CO}_{2} \mathrm{~m}^{-2}$ (Domysheva et al., 2013).

The Siberian lakes situated in tundra and forest-tundra zones are in general poorly studied. In their natural state, their productivity is low, but their ecosystems are highly sensitive to external influences. Profuse blooming of cyanobacteria is usually associated with urban and industrial effluents and nutrient run-off. An assessment is needed of the impact of climate change in the northern Eurasian region on eutrophication, accompanied by blooms of cyanobacteria. Besides, the northern Eurasian region is characterized by thaw lakes, which comprise $90 \%$ of the lakes in the Russian permafrost zone (Romanovsky et al., 2002). These lakes, which are formed in melting permafrost, have long been known to emit $\mathrm{CH}_{4}$. The latest observations of the lakes in the permafrost zone of northern Siberia indicate that they are releasing much more $\mathrm{CH}_{4}$ into the atmosphere than previously thought. Rather than being emitted in a constant flow, $95 \%$ of $\mathrm{CH}_{4}$ comes from random bubbling in disperse locations. In coming decades, this could become a more significant factor in global climate change (Walter et al., 2006).

One direct consequence of climate change is the explosive reproduction of toxic cyanobacteria (Nodularia, Microcystis, Anabaena, Aphanizomenon, Planktothrix) and diatoms (Pseudo-nitzschia) (Moore et al., 2008; Paerl and Huisman, 2009). These blooms occur in ponds, lakes, reservoirs, and bays of the sea. Cyanobacteria and diatoms excrete especially dangerous carcinogens and neurotoxins into the water. The toxicity of some cyanotoxins exceeds the toxicity of currently banned warfare agents. Antidotes to these toxins do not exist at the moment.

Water conservation has received an increasing attention in China, and multiple new projects have been initiated recently. Especially the construction of water transfer, reservoir, and irrigation schemes have received much attention, because the central and western regions of China are suffering from water shortages. These projects are expected to improve water usage and security, especially for agricultural activities, and to provide sufficient water resources for local societies. In China, the river systems are dominated by rivers flowing from the Tibetan plateau to the Pacific Ocean. The Yangtze is the longest river in China, and flows from the Tibetan plateau to Shanghai. The Yellow river is the second longest in China, and it is characterized by seasonal flooding, which causes great economic and societal losses. The Amur River forms the northern border with Russia. The Haihe River flows through Beijing to Tianjin, and is under heavy stress from the highly populated and industrialized capital metropolitan region. Only one river from China flows to the Arctic Ocean: the Ertix River, which flows to the north through Kazakhstan, across Siberian Russia, finally joining the Ob River, which flows to the Arctic Ocean. 


\subsection{Social system - state-of-the-art and future research needs}

\subsubsection{Land use and natural resources}

The fundamental large-scale task is to estimate how human actions such as land use changes, energy production, the use of natural resources, changes in energy efficiency, and the use of renewable energy sources will influence the environments and societies of the northern Eurasian region. For example, the industrial development of Siberia should be considered as one of most important drivers of future land use and land cover changes in Russia. Siberia is a treasure chest of natural resources of Russia, containing $85 \%$ of its prospected gas reserves, $75 \%$ of its coal reserves, and $65 \%$ of its oil reserves. Siberia has more than $75 \%$ of Russia's lignite, $95 \%$ of its lead, approximately $90 \%$ of its molybdenum, platinum, and platinoids, $80 \%$ of its diamonds, $75 \%$ of its gold, and $70 \%$ of its nickel and copper (Korytnyi, 2009).

During the 20th century, a considerable transformation of landscapes in the tundra and taiga zones in northern Eurasia has occurred as a result of various industrial, socio-economic and demographic processes, leading to the industrial development of previously untouched territories (Bergen et al., 2013). This has led to a decrease in the rural population and, mostly after the 1990s, to decrease in agricultural activities. There has also been a significant reduction in agricultural land use, and its partial replacement by zonal forest ecosystems (Lyuri et al., 2010). According to recent estimates, the total area of abandoned agricultural land in Russia in the 1990s to 2010s is at about 57 million ha, of which 18 million ha have been restored by forests and 6 million ha of this are located in Asian Russia (Schepaschenko et al., 2015). As a result, these areas have become active accumulators of atmospheric $\mathrm{CO}_{2}$ (Kalinina et al., 2009). These new forests (substituting resources) could form the basis for sustainable development in these regions, in case relevant management programs for the forests re-established on abandoned lands are going to be implemented.

The dynamics of land cover, particularly forests, have been documented since 1961 when the results of the first complete inventory of Russian forests were published. According to official statistics, the area of forests in Asian Russia increased by around 80 million ha during 1961-2009, mostly before the middle of the 1990s. This large increase is explained by improved quality of forest inventories in remote territories, natural reforestation, mostly during the Soviet era as a result of forest fire suppression, and encroaching forest vegetation in previously non-forested land. Based on official statistics, the area of cultivated agricultural land in the region decreased by around 10 million ha between 1990 and 2009. After the year 2000, the forested area in Siberia decreased, mostly due to fire and the impacts of industrial transformations in high latitudes (Shvidenko and Schepaschenko, 2014). A critical decrease in the forest area has also been observed in the most populated areas with intensive forest harvesting particularly in the southern part of Siberia and the Far East. For example, in the Krasnoyarsk Krai, the total area of forests decreased by $5 \%$, while that of mature coniferous forests decreased by $25 \%$. Overall, the typical processes in these regions are a dramatic decline in the quality of forests, unsustainable use of forest resources, and insufficient governance and forest management in the region, including frequent occurrence of illegal logging, natural, and human-induced disturbances (Shvidenko et al., 2013a).

Future land use and land cover changes will crucially depend on how successfully the strategy of sustainable development of northern territories is developed and implemented. An effective system for the adaptation of boreal forests to global change needs to be developed and implemented in the region. An "ecologization" of the current practices of industrial development of previously untouched territories would allow a substantial decrease in the physical destruction of landscapes, and halt the decline of surrounding ecosystems due to air pollution and water and soil contamination (Kotilainen et al., 2008).

The expected changes in the climate and environment will have multiple and complicated impacts on ecosystems, with consequent land cover changes. The alteration of fire regimes and the thawing of permafrost will intensify the process of "green desertification" in large areas. Climate warming will have multiple effects on soil-vegetation-snow interactions. For example, in a warmer climate, mosses and other vegetation grow faster, providing a better thermal insulation of the permafrost in summer, and better feeding conditions for reindeer. However, snow can also more easily accumulate on thicker vegetation, thus protecting the deeper soil from cooling during the winter (Tishkov, 2012).

Both north and east Russia possess abundant mineral resources (Korytnyi, 2009). The resource orientation of northern and eastern Russia's economy, which has not changed for centuries, increased in the post-Soviet period, and has been influenced primarily by the product market. It is also expected that the natural resource development sector will continue to dominate the economy in the majority of these territories for the next decades.

A crucial factor in greenhouse gas emission dynamics is the fuel balance. In Russia, features of the fuel balance have led to an increased pollution. On average, specific emissions in the northern and eastern cities of Russia, where coal accounts for most of the power generation, are 3 times higher than in cities where power is generated mainly from gas or fuel oil (Bondur, 2011a). The geographical location, undeveloped infrastructure, harsh climate, and coal burning are the main reasons for increased levels of anthropogenic pollution in these areas (Bondur and Vorobev, 2015; Bondur, 2014). In small towns, low-capacity boiler rooms are the main source of emissions. Usually, the lack of financial resources leads to the use of low-quality coal and obsolete boilers. In the steppe zone of Asian Russia, Mongolia, Kazakhstan, and Burya- 
tia, the main source of emissions is the burning of harvest residues.

The dynamics of GHG emissions in Russia are largely determined by the economic conditions of production. The economic crisis in 1990-1998 slowed down environmental degradation to some extent: emissions generally decreased by $40 \%$. However, the underlying environmental problems not only remained unresolved, but significantly deepened, and turned into systemic problems. The most polluting industries were more resistant to the decline in production. Technological degradation took place, cleaning systems were eliminated, and production shifted to part-time, leading to inefficient capacity utilization. Significant amounts of pollution continued to be emitted from the domestic sector. Emissions decreased in most regions of the country, and in $83 \%$ of the cities, but much more slowly than production. As a result, the specific emissions (per product cost at comparable prices) had grown by the end of the 1990s in all categories of cities, except cities with more than 1 million inhabitants (Bityukova et al., 2010). All this can cause negative impacts on ecosystems. For example, there are about 2 million ha of technogenic deserts around Norilsk. Norilsk is probably the biggest smelter in the world, and produces more than 2 million $t$ of pollutants per year (Groisman et al., 2013).

\subsubsection{Natural hazards}

\section{Extreme weather and fire occurrence}

The frequency and intensity of weather extremes have increased substantially during the last decades in Europe, Russia, and China. Further acceleration is expected in the future (IPCC, 2013). The evolving impacts, risks, and costs of weather extremes on population, environment, transport, and industry have so far not been properly assessed in the northern latitudes of Eurasia. New knowledge is needed for improving the forecasting of extreme weather events, for understanding the effect of wildfires on radiative forcing and atmospheric composition in the region, for estimating the impacts of weather extremes on major biogeochemical cycles, and for understanding the effects of disturbances in forests on the emissions of BVOC and VON (volatile organic nitrogen) (Bondur, 2011b, 2015; Bondur and Ginsburg, 2016). How do changes in the physical, chemical and biological state of the different ecosystems and the inland, water, and coastal areas affect the economies and societies in the region, and vice versa?

The number of large hydrometeorological events in Russia that cause substantial economic and social losses has increased by more a factor of 2 from 2001 to 2013 (State Report, 2011). The main hazards are related to atmospheric processes on various temporal and spatial scales, including strong winds, floods and landslides caused by heavy precipitation, and fires caused by drought and extreme temperatures. High temperatures and long droughts can substantially de- crease the productivity and cause high dieback in dark coniferous forests. Hurricanes occur fairly often in the forest zone. For example, a hurricane destroyed about 78000 ha of forest in the Irkutsk region in July 2004 (Vaschuk and Shvidenko, 2006). However, there are no reliable statistics on many types of natural hazards.

In order to build scenarios of the future frequency and properties of weather-related hazards, one should first analyse the atmospheric mechanisms behind the circulation structures responsible for these hazards: the cyclones related to strong winds and heavy precipitation and the anticyclones related to drought and fires episodes. Studying the cyclone/anticyclone tracks, frequency and intensity can provide a statistical basis for understanding the geographical distribution and properties of the major atmospheric hazards and extremes (e.g. Shmakin and Popova, 2006). For future climate projections, atmospheric hazards and extremes should be interpreted from the viewpoint of cyclone/anticyclone statistics, and possible changes in the cyclone/anticyclone geography and frequency should be analysed.

Fires are the most important natural disturbances in the boreal forests. Fires strongly determine the structure, composition, and functioning of the forest. Each year, about $0.5-1.5 \%$ of the boreal forest burns. Since boreal forests cover $15 \%$ of the Earth's land surface, this is a significant area (Kasischke, 2000; Conard et al., 2002; Bondur, 2011b, 2015). Climate change already substantially impacts fire regimes in northern Eurasia. More frequent and severe catastrophic (mega-) fires have become a typical feature of the fire regimes. Such fires envelope areas of up to a hundred thousand hectares within large geographical regions, lead to the degradation of forest ecosystems, decrease the biodiversity, may spread to usually unburned wetlands, cause large economic losses, deteriorate life conditions and health of local populations, and lead to "green desertification", which is an irreversible transformation of the forest cover for long periods (Shvidenko and Schepaschenko, 2013; Bondur, 2011b, 2015). Megafires also lead to specific weather conditions over the affected areas that are comparable in size to largescale pressure systems ( $\sim 30$ million ha and more). The annually burned area in the Russian territory was estimated to be $8.2 \pm 0.8 \times 10^{6}$ ha during $1998-2010$, and about twothirds of this area consisted of boreal forests. For this period, the fire carbon balance (total amount of carbon in the burnt fuel) was estimated to be $121 \pm 28 \mathrm{Tg} \mathrm{C} \mathrm{yr}^{-1}$ (Shvidenko et al., 2011). Current model projections suggest that the number of fires will double by the end of this century. The extent of catastrophic fires escaping from the control and fire intensity are projected to increase. Due to increased severity of fire and deeper soil, carbon emissions from fires are predicted to increase by a factor of 2 to 4 (Gromtsev, 2002; Malevsky-Malevich et al., 2008; Flanningan et al., 2009; Shvidenko et al., 2011). During and after fires, significant changes take place in the forest ecosystems, including the soil. These changes include (i) a significant amount of 
biomass is combusted, and large amounts of carbon and nitrogen are released to the atmosphere in the form of carbon dioxide and other gases or particles (Harden et al., 2000; Andreae and Merlet, 2001; Kaiser et al., 2012; Konovalov et al., 2014; L. Kulmala et al., 2014); (ii) fire alters the microbial community structure in the soil as well as the structure of the vegetation (Dooley and Treseder, 2012; Sun et al., 2015); (iii) fires determine the structure of the vegetation, succession dynamics and the fragmentation of forest cover, tree species composition, and the productivity of boreal forests (Gewehr et al., 2014), and (iv) fire is one of the crucial drivers controlling the dynamics of the carbon stock of boreal forests (Jonsson and Wardle, 2010; Köster et al., 2014).

Disturbances resulting from fire, pest outbreaks, and diseases also have substantial effects on the emissions of BVOCs and volatile organic nitrogen compounds (Isidorov, 2001), and consequently on atmospheric aerosol formation. The acceleration of fire regimes will also affect the amount of black carbon in the atmosphere, and thus has an effect on the albedo of the cryosphere.

\section{Permafrost degradation and infrastructures}

The degradation of permafrost will cause serious damage both to infrastructure and to ecosystems and water systems in the northern Eurasian region. This includes, for example, damage to pipelines and buildings, deformation of roads and railroads in Russia, Mongolia, and China, variations in the ion distribution in soil water in young and ancient landslides, cryogenic landslides, spatial and temporal changes of grass and willow vegetation, saline water accumulation in local depressions of the permafrost table, and formation of highly saline lenses of groundwater called "salt traps".

Due to the large extent of permafrost-covered areas in northern Eurasia (for ecosystem effects, see Sect. 2.1.1 and 2.1.2), there are numerous infrastructural issues related to possible changes in the thickness and temperature of the frozen part of the subsurface, and thus in the mechanical soil properties. Climate change-induced changes in the cryosphere are probably among the most dramatic issues affecting the infrastructure in northern Eurasia, as this infrastructure is literally standing on permafrost. Moreover, an interesting coupling may be related to the decreasing ice-cover of the Arctic Ocean, which results in increased humidity and precipitation on the continent, and thus a further thickening and longer duration of the annual snow cover. Snow is a good thermal insulator, and influences the average ground surface temperature, thus playing a potentially important role in speeding up the thawing of permafrost.

The increased risk of damage to local infrastructure, such as buildings and roads, can cause significant social problems, and exerts pressure on the local economies. Thawing permafrost is structurally weak, and places a variety of infrastructure at risk. For example, the failure of buildings, roads, pipelines, or railways can have dramatic environmental con- sequences, as seen in the 1994 breakdown of the pipeline to the Vozei oilfield in northern Russia, which resulted in a spill of $160000 \mathrm{t}$ of oil - the world's largest terrestrial oil spill (United Nations Environment Program, 2013). Maintenance and repair costs related to permafrost thaw and degradation of infrastructure in northern Eurasia have recently increased, and will most probably increase further in the future. This is an especially prominent problem in discontinuous permafrost regions, where even small changes in the permafrost temperature can cause significant damage to infrastructure. Most settlements in permafrost zones are located on the coast, where strong erosion places structures and roads at risk. After damage to the infrastructure, local residents and indigenous communities are often forced to relocate. This can cause changes in, or even disappearances of, local societies, cultures, and traditions (United Nations Environment Program, 2013).

\section{Changing sea environments and the risk of accidents in coastal regions}

In northern Eurasia, from the eastern part of the Barents Sea to the Bering Sea, the permafrost is located directly on the seacoast. In many of these coastal permafrost areas, sea level rise and continuing permafrost degradation leads to significant coastal erosion, and to the possibility of a collapse of coastal constructions, lighthouses, ports, houses, etc. In this region, the sea level rise is coupled to the permafrost degradation in a complex way, and should be focused on in future studies.

Understanding and measuring artificial radionuclides in marine ecosystems is needed for improving emergency preparedness capabilities, and for developing risk assessments of potential nuclear accidents. The awareness of the general public and associated stakeholders across the region should also be raised concerning the challenges and risks associated with nuclear technologies, environmental radioactivity, and emergency preparedness. The current state of radioactive contamination in terrestrial and marine ecosystems in the European Arctic region will be studied by examining environmental samples collected from Finnish Lapland, Finnmark, and Troms in Norway, the Kola Peninsula, and the Barents Sea. The results will provide updated information on the present levels, occurrence and fate of radioactive substances in the Arctic environments and food chains. The results will also allow us to estimate where the radioactive substances originate from, and what risks they may pose in case of accidents.

Annual expeditions for sample collection are needed for the development of models to predict the distribution of radionuclides in the northern marine environment, and for the assessment of the current state of radioactive contamination in marine ecosystems in the European Arctic region. In view of recent developments and increased interests in the European Arctic region for oil and gas extraction, special atten- 
tion needs to be given to the analysis of norms (naturally occurring radioactive materials) in order to understand current levels. The future focus should be put on atmospheric modelling, and on the assessment of radionuclide distributions in the case of accidents leading to the release of radioactive substances to the environment in the European Arctic region. This includes the assessment of nuclear accident scenarios for dispersion modelling.

\subsubsection{Social transformations}

Climate and weather strongly affect the living conditions, mostly in the Eastern part of the northern Eurasian societies, influencing people's health, incidence of diseases and adaptive capacity. The vulnerability of societies, including their adaptive capacity, varies greatly depending on both their physical environment, and on their demographic structure and economic activities. There is a need to analyses the scientific background and robustness of the adaptation and mitigation strategies (AMS) of the region's societies, and their resilience capacity, with special emphasis on the forest sector and agriculture. The future research needs are in understanding what ways populated areas are vulnerable to climate change; how their vulnerability can be reduced and their adaptive capacities improved; what responses should be identified to mitigate and adapt to climate changes.

Health issues are also important in multi-disciplinary studies of northern Eurasia, as the living conditions of both humans and livestock are changing dramatically. SLCF, such as black carbon, ozone, and aerosol particles, are important players in both air quality and Arctic climate change and their impacts are not yet quantified. Black carbon has a special role when designing future emission control strategies, since it is the only major aerosol component whose reduction is likely to be beneficial to both climate and human health. These changes can be expressed through complex parameters combining the direct effects of, e.g., temperature and wind speed, with indirect effects of several climatic and non-climatic factors such as the atmospheric pressure variability, or the frequency of unfavourable weather events, e.g. heat waves or strong winds. During the last decades, living conditions in northern Eurasia have generally improved, but with a significant regional and seasonal variation (Zolotokrylin et al., 2012).

Both northern and eastern Eurasia have small and diminishing populations, mainly due to the migration outflow started in the 1990s due to severe and unfavourable living conditions combined with changing state policies with respect to the development of the northern territories. This reversed the previous long-standing pattern of migration inflow. The combination of outflow and natural population decrease (with some regional exceptions in several ethnic republics and autonomous regions (okrugs) with oil and gas industry) led to a steady population decline in most regions in northern and eastern Russia from 1990s. In the post-soviet period, the population of eastern Russia decreased by 2.7 million, while the population of Russia's Arctic zone decreased by nearly by one-third (500000 people), in contrast to the majority of the world's Arctic territories (Glezer, $2007 \mathrm{a}, \mathrm{b})$. The population change in north-eastern Russia was particularly remarkable: the Chukotka Autonomous Okrug lost $68 \%$ of its population, the Magadan Oblast lost $59 \%$, and the Kamchatka Krai lost $33 \%$.

Geographical and ethnic factors influence the demography and settlement pattern in the region. Geographical factors include environmental conditions and the mixture of urban and rural territories. Areas with a large proportion of indigenous people employed in traditional nature management were exposed to relatively small post-soviet transformations in the 1990s and 2000s. In contrast, the largest transformations occurred in areas with a larger proportion of Russian people and developed mining industries. The differences in the transformations between settlements with predominantly indigenous and predominantly Russian populations are evident. For example, in the Chukotka Autonomous Okrug, the former remained mostly intact, with only small decreases in population, while the latter disappeared entirely or were significantly depopulated (Litvinenko, 2012, 2013).

When assessing the impacts of climate change and other environmental changes on human societies, it should be taken into account that the urban environments in northern Eurasian cities and towns situated in the less favoured regions are currently incapable of mitigating unfavourable impacts. The impact of climate parameters, such as temperature (including seasonal, weekly, and daily cycles, and extreme values), strong winds, snowfall, snowstorms, and precipitation should be investigated. Both the frequency and the duration of weather events should be considered. These climate parameters influence human health, incidence of diseases, adaptation potential, and economic development in general. Furthermore, it is important to explore the interactions between the environmental change and post-soviet transformations of natural resource utilization in northern Eurasia in order to assess the complexity of their socioecological consequences at regional and local levels (Litvinenko, 2012; Tynkkynen, 2010). The population dynamics of the northern Russian regions in 1990-2012, and the linkage between intra-regional differences in population dynamics, spatial transformations of natural resources utilization, and ethnic composition of the populations should be clarified. It would be desirable to develop an "early warning system" for the timely mitigation of the negative socio-ecological effects of both environmental changes, and changes in the availability of natural resources as well as accident like leakages in gas and oil pipelines. Such systems would be useful for federal, regional, and local authorities as well as for local communities.

It should also be taken into account that the majority of the world's ethnic groups are small and engaged in culturally specialized methods of subsistence, so any change in their 
immediate environment may lead to their traditional way of life becoming unsustainable. These changes may be due to rising sea levels, warming seawater, melting ice cover, thawing permafrost, flooding rivers, changing rain patterns, or moving vegetational zones. These are direct effects of climate change and environmental deterioration on ethnodiversity. However, even more threatening are the indirect effects. The immediate environment of small ethnic groups is often vulnerable to the adverse impact of majority populations representing governments and nations. The effects of climate change may lead to a rapid and massive transfer of majority populations to areas previously inhabited by small ethnic groups.

\section{From process studies towards system understanding and quantification of feedbacks of Arctic-boreal regions}

The system understanding helps us to understand the behaviour of feedbacks between the land, atmosphere, aquatic, and societal/economic systems. To be able to provide a system understanding, we need to understand the individual processes, and based on process understanding we are then able to quantify different biogeochemical cycles. Via biogeochemical cycles, the energy and matter flows are linked to a wider system context, which enables us to analyse the feedback phenomena. Feedbacks are essential components of our climate system, as they either increase or decrease the changes in climate-related parameters in the presence of external forcings (IPCC, 2013).

The effects of climate change on biogeochemical cycles are still inadequately understood, and many feedback mechanisms are difficult to quantify (Arneth et al., 2010; M. Kulmala et al., 2014). They are related to, for example, the coupling of carbon and nitrogen cycles, permafrost processes and ozone phytotoxicity (Arneth et al., 2010), or to the emissions and atmospheric chemistry of biogenic volatile organic compounds (Grote and Niinemets, 2008; Mauldin et al., 2012), subsequent aerosol formation processes (Kulmala et al., 2004b; Tunved et al., 2006; Kulmala et al., 2011a; Hirsikko et al., 2011) and aerosol-cloud interactions (McComiskey and Feingold, 2012; Penner et al., 2012; Rosenfeld et al., 2014).

The northern Eurasian Arctic-boreal geographical region covers a wide range of interactions and feedback processes between humans and natural systems. Humans are acting both as the source of climate and environmental changes, and as recipient of their impacts. The PEEX research agenda is addressing the most relevant research topics related to the process dynamics in the land, atmospheric, aquatic, and society systems relevant to northern regions. PEEX also aims to quantify the range of emissions and fluxes from different types of ecosystems and environments and links to ecosystem productivity (see also $\mathrm{Su}$ et al., 2011; Kulmala and
Petäjä, 2011; Bäck et al., 2010). This new knowledge helps us to obtain a holistic view on the changes in biogeochemical cycles and feedbacks in the future Arctic-boreal system (Fig. 4). PEEX will also to take into consideration that there may exist previously unknown sources and processes ( $\mathrm{Su}$ et al., 2011; Kulmala and Petäjä, 2011; Bäck et al., 2010).

Holistic representations of feedback loops potentially relevant to Arctic-boreal systems have been given by Charlson et al. (1987), Quinn and Bates (2011), and by M. Kulmala et al. (2004a, 2014). The "CLAW" hypothesis (the CLAW acronym refers to Charlson, Lovelock, Andreae and Warren) connects the ocean biochemistry and climate via a negative feedback loop involving cloud condensation nuclei production due to dimethylsulfoniopropionate (DMSP) and dimethyl sulfide (DMS) biosynthesis by marine phytoplankton (e.g. Quinn and Bates, 2011; Ducklow et al., 2001; O'Dowd et al., 2004; de Leeuw et al., 2011; Malin et al., 1993; O'Dowd and de Leeuw, 2007). The COBACC (COntinental Biosphere-Aerosol-Cloud-Climate) hypothesis suggests two partly overlapping feedbacks that connect the atmospheric carbon dioxide concentration, ambient temperature, gross primary production, biogenic secondary organic aerosol formation, clouds, and radiative transfer (M. Kulmala et al., 2004a, b, 2014; also see Sect. 2.1.1.). The quantification of these feedback loops under changing climate is crucial for reliable Earth system modelling and predictions.

In the context of the COBACC feedback loop, the key large-scale research questions are the changing cryospheric conditions and consequent changes in ecosystem feedbacks affecting the Arctic-boreal climate system and weather. Furthermore, we should estimate the net effects of various feedback effects (CLAW, COBACC) on land cover changes, photosynthetic activity, GHG exchanges, BVOC emissions, aerosol and cloud formation, and radiative forcing at regional and global scales. In our analysis, we should also take into account the urbanization processes and social transformations (see Sect. 2.4.3), which are changing the regional climates. In this task, we should also study the key gaps of the biogeochemical cycles.

\subsection{Hydrological cycle}

Climate change may profoundly affect most of the components of the hydrological cycle, giving rise to positive or negative feedbacks (Fig. 5). While variations in the hydrological cycle often take place at regional or local scales, they can also give rise to large-scale or even global changes. Knowledge of the hydrological cycle in general and particularly related to permafrost is crucial for predicting the resilience and transformation of forest ecosystems coupled with permafrost (Osawa et al., 2010).

In addition to permafrost processes, another important issue in high latitudes is precipitation. Precipitation is a critical component of the hydrological cycle, having a great spatial and temporal variability. The lack of understanding 


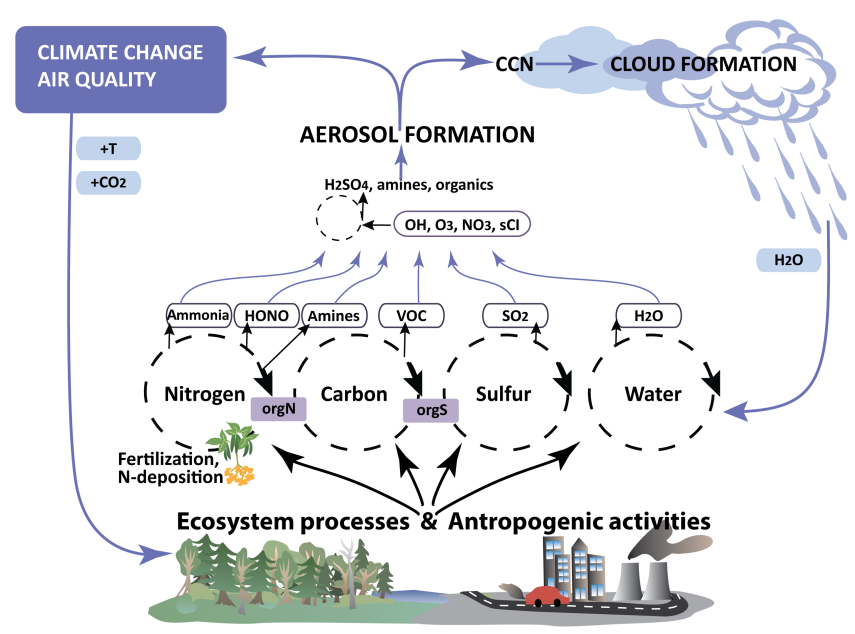

Figure 4. In urban and industrialized regions, the process understanding of biogeochemical cycles includes anthropogenic sources, such as industry and fertilizers, as essential parts of the biogeochemical cycles.

of some precipitation-related processes, combined with the lack of global measurements of sufficient detail and accuracy, limits the quantification of different components of the hydrological cycle such as precipitation, evapotranspiration, or CCN formation. This is especially true in high-latitude regions, where observations and measurements are particularly sparse, and processes poorly understood.

Recent retrievals of multiple satellite products for each component of the terrestrial water cycle provide an opportunity to estimate the water budget globally (Sahoo et al., 2011) (Fig. 5). Global precipitation is retrieved at very high spatial and temporal resolution by combining microwave and infrared satellite measurements (Sorooshian et al., 2000; Kummerow et al., 2001; Joyce et al., 2004; Huffman et al., 2007). Large-scale estimates of global precipitation have been derived by applying energy balance, process, and empirical models to satellite-derived surface radiation, meteorology, and vegetation characteristics (e.g. Mu et al., 2007; Su et al., 2007; Fisher et al., 2008; Sheffield et al., 2010). The water storage change component can be obtained from satellite data, and the water level in lakes and large-scale river systems can be estimated from satellite altimetry with special algorithms developed for terrestrial waters (Berry et al., 2005; Velicogna et al., 2012; Troitskaya et al., 2012, 2013).

\subsection{Carbon cycle}

It is not clear how future climate will modify incoming terrestrial net primary production (NPP) and outgoing (e.g. heterotrophic soil respiration, HSR) carbon fluxes to and from terrestrial ecosystems. It is likely that the transformation of Russian forests is a tipping element for the climate system by the end of the century over huge areas, even though un-

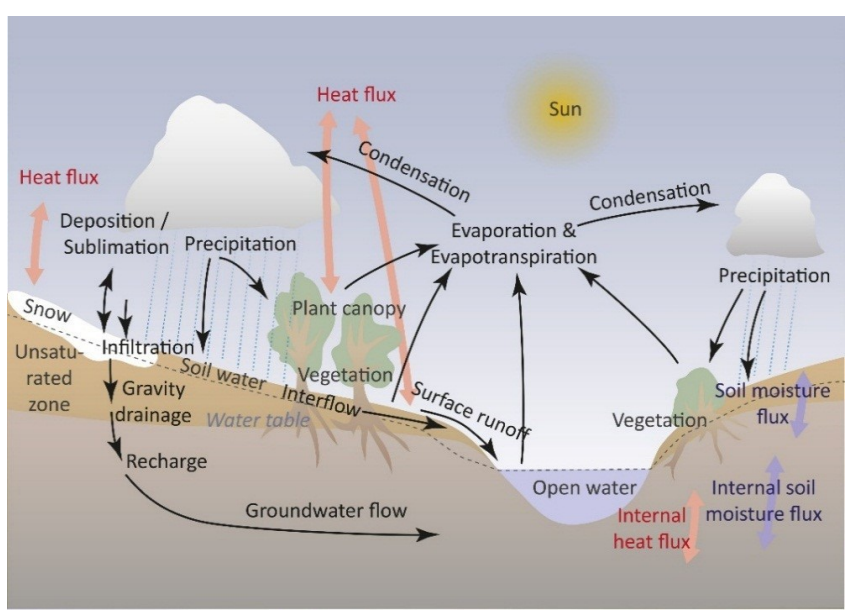

Figure 5. Hydrological cycle schematics.

certainties in such forecasts are significant (Gauthier et al., 2015). The role of boreal and Arctic lakes and catchment areas in carbon storage dynamics is poorly quantified (Fig. 6).

The terrestrial biosphere is a key regulator of atmospheric chemistry and climate via its carbon uptake capacity (Arneth et al., 2010; Heimann and Reichstein, 2008). The Eurasian area holds a large pool of organic carbon both within the above- and below-ground living biota, in the soil, and in frozen ground, stored during the Holocene and the last ice age. The area also contains vast stores of fossil carbon. According to estimates of carbon fluxes and stocks in Russia made as part of a full carbon account by the land-ecosystem approach (Shvidenko et al., 2010; Schepaschenko et al., 2011; Dolman et al., 2012), terrestrial ecosystems in Russia served as a net carbon sink of $0.5-0.7 \operatorname{Pg}(\mathrm{C})$ per year during the last decade. Forests provided above $90 \%$ of this sink. The spatial distribution of the carbon budget shows considerable variation, and substantial areas, particularly in permafrost regions and in disturbed forests, display both sink and source behaviour. The already clearly observable greening of the Arctic is going to have large consequences on the carbon sink in the upcoming decades (Myneni et al., 1997; Zhou et al., 2001), although future predictions are uncertain. The net ecosystem carbon budget (NECB) or net biome production (NBP) are usually a sensitive balance between carbon uptake through forest growth, ecosystem heterotrophic respiration, and carbon release during and after disturbances such as fire, insect outbreaks, or weather events, e.g. as exceptionally warm autumns (Piao et al., 2008; Vesala et al., 2010). This balance is delicate, and for example in the Canadian boreal forest the estimated net carbon balance is close to carbon neutral due to fires, insects, and harvesting cancelling the carbon uptake from forest net primary production (Kurz and Apps, 1995; Kurz et al., 2008b). Long-term measurements of the concentrations of $\mathrm{CO}_{2}$ and other carbon gases at selected sites, especially using tall towers such as the ZOTTO 


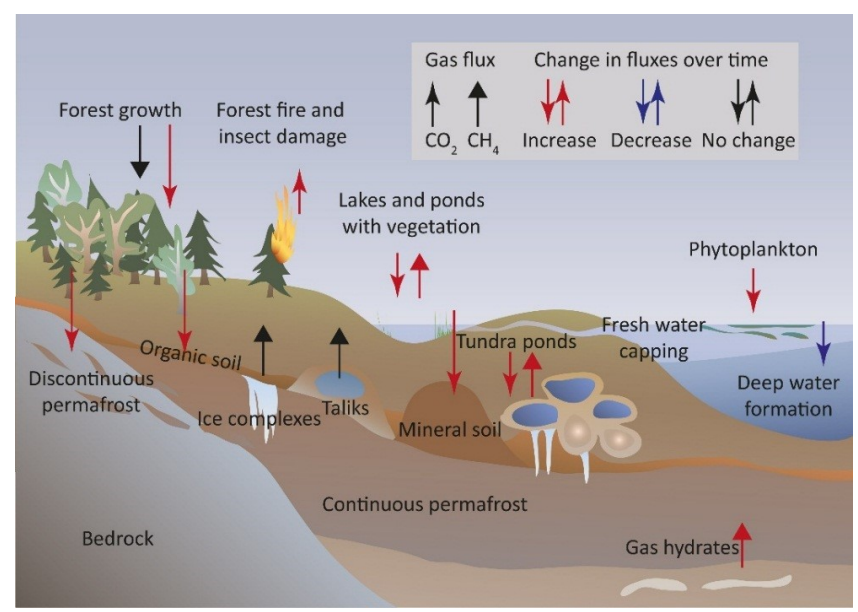

Figure 6. Carbon cycling in the Arctic will change as the climate warms. Figure after ACIA, 2004 (Arctic Climate Impact Assessment, 2004).

tower, will be essential for constraining the large-scale carbon fluxes in the PEEX region (Heimann et al., 2014).

Plant growth and carbon allocation in boreal forest ecosystems depend critically on the supply of recycled nutrients within the forest ecosystem. In the nitrogen-limited boreal and Arctic ecosystems, the biologically available nitrogen $\left(\mathrm{NH}_{4}\right.$ and $\left.\mathrm{NO}_{3}\right)$ is in short supply, although the flux of assimilated carbon below ground may stimulate the decomposition of nitrogen-containing soil organic matter (SOM), and the nitrogen uptake of trees (Drake et al., 2011; Phillips et al., 2011). The changes in easily decomposable carbon could enhance the decomposition of old SOM (Kuzyakov, 2010; Karhu et al., 2014), and thus increase the turnover rates of nitrogen in the rhizosphere, with possible growth-enhancing feedbacks on vegetation (Phillips et al., 2011).

Arctic warming is promoting terrestrial permafrost thaw and shifting hydrologic flow paths, leading to fluvial mobilization of ancient carbon stores (Karthe et al., 2014). Observed permafrost thaw acts as a significant and preferentially degradable source of bioavailable carbon in Arctic freshwaters, which is likely to increase as permafrost thaw intensifies, causing positive climate feedbacks in response to ongoing climate change (Mann et al., 2012). Significant differences in fluvial carbon input between headwaters and downstream reaches of large Arctic catchments (Yenisey and Lena) have been identified, but the problem is until now very poorly explained. At the same time, the fluvial export by the largest rivers is considered to be an order of magnitude less than coastal erosion in the East Siberian Arctic Shelf (Semiletov et al., 2011). The Lena's particulate organic carbon export is estimated to be 2 orders of magnitude less than the annual input of eroded terrestrial carbon onto the shelf of the Laptev and East Siberian seas.

Although inland waters are especially important as lateral transporters of carbon, their direct carbon exchange with the atmosphere, so-called outgassing, has been recognized to be a significant component in the global carbon budget (Bastviken et al., 2011; Regnier et al., 2013). In the boreal pristine regions, forested catchment lakes can vent ca. $10 \%$ of the terrestrial NEE (net ecosystem exchange), thus weakening the terrestrial carbon sink (Huotari et al., 2011). There is a negative relationship between the lake size and gas saturation, and especially small lakes are relatively large sources of $\mathrm{CO}_{2}$ and $\mathrm{CH}_{4}$ (e.g. Kortelainen et al., 2006; Vesala et al., 2012). However, on a landscape level, large lakes can still dominate the GHG fluxes. Small lakes also store relatively larger amounts of carbon in their sediments than larger lakes. The role of lakes as long-term sinks of carbon, and simultaneously as clear emitters of carbon-containing gases, is strongly affected by the physics of the water column. In lakes with very stable water columns and anoxic hypolimnion sediments, carbon storage is especially efficient, but at the same time, these types of lakes emit $\mathrm{CH}_{4}$. In general, the closure of landscape-level carbon balances is virtually impossible without studying the lateral carbon transfer processes (Pumpanen et al., 2014), and the role of lacustrine ecosystems as GHG sources/sinks. Besides lakes, these studies should include rivers and streams, which could be even more important than lakes as transport routes of terrestrial carbon and as emitters of GHGs (Huotari et al., 2013). In addition, the role of VOC emissions as a part of the carbon budget needs to be quantified.

\subsection{Nitrogen cycle}

Nitrogen is the most abundant element in the atmosphere. However, most of the atmospheric nitrogen is in the form of inert $\mathrm{N}_{2}$, which is unavailable most for plants and microbes, and can only be assimilated into terrestrial ecosystems through biological $\mathrm{N}_{2}$ fixation (Canfield et al., 2010). Only cryptogamic covers and certain organisms living in symbiosis with plants are capable of nitrogen fixation, making nitrogen the main growth-limiting nutrient in terrestrial ecosystems (Elbert et al., 2012; Lenhart et al., 2015). Human perturbations to the natural nitrogen cycle have, however, significantly increased the availability of nitrogen in the environment (Fig. 7). These perturbations mainly stem from the use of fertilizers in order to increase crop production to meet the demands of the growing population (Sutton et al., 2010), although atmospheric nitrogen deposition may also play a significant role in some areas. The increased use of fertilizer nitrogen, and consequent perturbations in nitrogen cycling, also cause severe environmental problems such as eutrophication of terrestrial and aquatic ecosystems, atmospheric pollution, and groundwater deterioration (Sutton et al., 2010).

Emission of reactive nitrogen $\left(\mathrm{NO}, \mathrm{NO}_{2}, \mathrm{HONO}\right.$, ammonia, amines) from soils (Su et al., 2011; Korhonen et al., 2013), fossil fuel burning, and other sources links the nitrogen cycle to atmospheric chemistry and secondary aerosol 


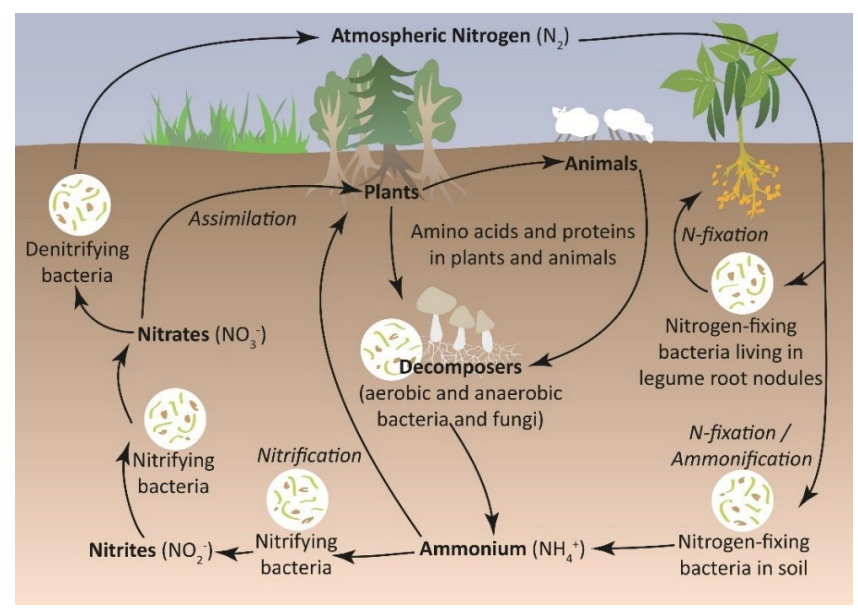

Figure 7. Schematic figure for terrestrial nitrogen cycle.

formation in the atmosphere. There are indications that emissions of $\mathrm{N}_{2} \mathrm{O}$ from the melting permafrost regions in the Arctic may significantly influence the global $\mathrm{N}_{2} \mathrm{O}$ budget and hence contribute to the positive radiative forcing by greenhouse gases (Repo et al., 2009; Elberling et al., 2010).

In natural terrestrial ecosystems, nitrogen availability limits ecosystem productivity, linking the carbon and nitrogen cycles closely together (Gruber and Galloway, 2008). The increasing temperatures due to climatic warming accelerate nitrogen mineralization in soils, leading to increased nitrogen availability and transport of reactive nitrogen from terrestrial to aquatic ecosystems. This perturbed and accelerated nitrogen cycling may lead to large net increases in the carbon sequestration of ecosystems (Magnani et al., 2007). The large surface area of boreal and Arctic ecosystems implies that even small changes in nitrogen cycling or feedbacks to the carbon cycle may be important on the global scale (Erisman et al., 2011). For instance, increased atmospheric nitrogen deposition has led to higher carbon sequestration in boreal forests (Magnani et al., 2007). However, the feedback mechanisms from increased perturbations of the nitrogen cycle may change the dynamics of the emissions of other greenhouse gases, hence complicating the overall effects. For instance, the stimulated carbon uptake of forests due to increased atmospheric nitrogen deposition can largely be offset by the simultaneously increased soil $\mathrm{N}_{2} \mathrm{O}$ emissions (Zaehle et al., 2011). In the Arctic, the melting permafrost may lead to high emissions of $\mathrm{N}_{2} \mathrm{O}$ (Repo et al., 2009; Elberling et al., 2010), which may significantly influence the global $\mathrm{N}_{2} \mathrm{O}$ budget.

Understanding the processes within the nitrogen cycle, the interactions of reactive nitrogen with the carbon and phosphorus cycles, atmospheric chemistry and aerosols, as well as their links and feedback mechanisms, is therefore essential in order to fully understand how the biosphere affects the atmosphere and the global climate (Kulmala and Petäjä, 2011).

\subsection{Phosphorus cycle}

Phosphorus $(\mathrm{P})$ is, together with nitrogen $(\mathrm{N})$, one of the limiting nutrients for terrestrial ecosystem productivity and growth, while in marine ecosystems, phosphorus is the main limiting nutrient for productivity (Whitehead and Crossmann, 2012). The role of $P$ in nutrient limitation in natural terrestrial ecosystems has not been recognized as widely as that of N (Vitousek et al., 2010).

In the global phosphorus biogeochemical cycle, the main reservoirs are in continental soils, where phosphorus in mineral form is bound to soil parent material, and in ocean sediments (Fig. 8). Sedimentary phosphorus originates from riverine transported material eroded from continental soils. The atmosphere plays a minor role in the phosphorus cycle, and the phosphorus cycle does not have a significant atmospheric reservoir. Atmospheric phosphorus mainly originates from aeolian dust, sea spray, and combustion (Wang et al., 2014). Gaseous forms of phosphorus are scarce, and their importance for atmospheric processes is unknown (Glindemann et al., 2005).

South-western Siberian soils have lately been reported to contain high concentrations of plant-available phosphorus (Achat et al., 2013), which may enhance the carbon sequestration of the ecosystems if they are not too limited by nitrogen. In soils, phosphorus is found mainly in mineral form and bound to the soil parent material such as apatite minerals. The amount of phosphorus in the parent material is a defining factor for phosphorus limitation, and the weathering rate determines the amount of phosphorus available for ecosystems. In ecosystems, most of the available phosphorus is in organic forms (Achat et al., 2013; Vitousek et al., 2010). In ecosystems growing on phosphorus-depleted soils, the productivity is more likely to be nitrogen-limited in early successional stages, and gradually shift towards phosphorus limitation as the age of the site increases (Vitousek et al., 2010). In freshwater ecosystems, excess phosphorus leads to eutrophication, which has ecological consequences, such as the loss of biodiversity due to changes in physicochemical properties and in species composition (Conley et al., 2009). Due to the scarcity of studies focusing on ecosystem phosphorus cycling, the effects of climate change on physicochemical soil properties and phosphorus availability, and the interactions of the phosphorus cycle with the cycles of carbon and nitrogen, are largely unknown.

\subsection{Sulfur cycle}

Sulfur is released naturally through volcanic activity as well as through weathering of the Earth's crust. The largest natural atmospheric sulfur source is the emission of DMS from oceanic phytoplankton (Andreae, 1990). DMS is converted to sulfur dioxide $\left(\mathrm{SO}_{2}\right)$, sulfuric acid $\left(\mathrm{H}_{2} \mathrm{SO}_{4}\right)$, and methyl sulfonic acid (MSA) via gas-phase oxidation. However, human activities have a major effect on the global sulfur cycle 


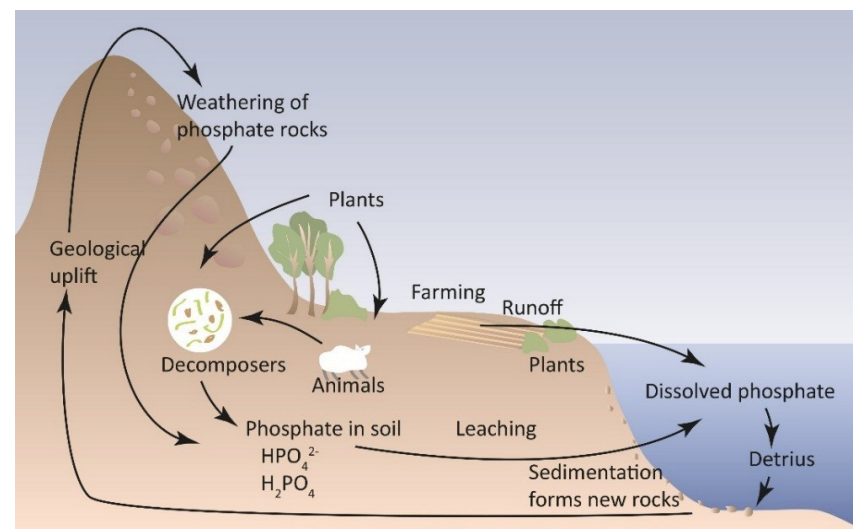

Figure 8. Schematic figure of the phosphorus cycle.

via vast emissions of $\mathrm{SO}_{2}$ from fossil fuel burning and smelting activities. The main sink of $\mathrm{SO}_{2}$ is oxidation to sulfuric acid in both gas and liquid phases, and subsequent removal from the atmosphere via precipitation and dry deposition.

Global anthropogenic $\mathrm{SO}_{2}$ emissions are predicted to decrease significantly by the year 2100 (IPCC SRES, 2000). Emissions in Europe and North America started to decrease already in the 1970s, but this decrease is still overwhelmed on a global scale by increasing emissions in eastern Asia and other strongly developing regions of the world (Smith et al., 2011). The current global anthropogenic $\mathrm{SO}_{2}$ emissions are about $120 \mathrm{Tg}$ per year, with Europe, the former Soviet Union and China together responsible for approximately $50 \%$ (Smith et al., 2011). Global natural emissions of sulfur, including DMS, are significantly smaller (a few tens of Tg per year; Smith et al., 2001). Anthropogenic emissions dominate especially over the continents. The main sources of $\mathrm{SO}_{2}$ are coal and petroleum combustion, metal smelting, and shipping, with minor contributions from biomass burning and other activities.

$\mathrm{SO}_{2}$ emissions in Eurasia have a large spatial variability. Smelters in the Russian Arctic areas emit vast amounts of $\mathrm{SO}_{2}$, significantly affecting the regional environment. In 2007 Blacksmith Institute experts estimated, that the smelter complexes in Norilsk, with annual emissions of $2 \mathrm{Tg}$ are alone responsible for more than $1.5 \%$ of global $\mathrm{SO}_{2}$ emissions. However, the emissions from the smelters in the Kola Peninsula, while still remarkably high, have decreased significantly during the past decades (Paatero et al., 2008), thus altering the impact of human activities on the regional climate and environment. In general, existing anthropogenic activities are slowly becoming more sulfur-effective and less polluting. However, the emergence of new sulfur-emitting activities and infrastructures partially counteracts this development.

The behaviour of future changes in $\mathrm{SO}_{2}$ emissions in the PEEX research area is uncertain. In northern Eurasia, natural resources like fossil fuels, metals, minerals, and wood are vast, and their utilization is becoming more and more attractive due increasing demand. This will most likely lead to an increase in human activities (e.g. mining, oil drilling, shipping) in this area (e.g. Smith, 2010, and references therein). For example, sulfur emissions in China increased rapidly until 2006, and then decreased by $9.2 \%$ to $30.8 \mathrm{Tg}$ in 2010 due to the wide application of flue-gas desulfurization (FGD) equipment in power plants (Lu et al., 2011). Sulfur emissions in Europe have decreased significantly during the last decades (Jones and Harrison, 2011).

Most of the natural and anthropogenic $\mathrm{SO}_{2}$ is removed from the atmosphere by liquid-phase oxidation to $\mathrm{H}_{2} \mathrm{SO}_{4}$, and subsequent precipitation. In areas with high sulfur loadings, acid rain leads to acidification of soils and waters (Fig. 9). The main final sink of sulfur is the oceans. A fraction of $\mathrm{SO}_{2}$ is oxidized to $\mathrm{H}_{2} \mathrm{SO}_{4}$ in the gas phase in a reaction chain initiated by the reaction of $\mathrm{SO}_{2}$ with the hydroxyl radical, OH. Especially in forested areas of Eurasia, reactions of $\mathrm{SO}_{2}$ with a second important oxidant type, the stabilized Criegee intermediates originating from biogenic VOC emissions, also produce significant amounts of $\mathrm{H}_{2} \mathrm{SO}_{4}$ (Mauldin et al., 2012). Gas-phase sulfuric acid plays a key role in the Earth's atmosphere by triggering secondary aerosol formation, thus connecting anthropogenic $\mathrm{SO}_{2}$ emissions to global climate via aerosol-cloud interactions. Particles containing sulfuric acid, or sulfate, are also connected with air quality problems and human health deterioration. Understanding the spatial and temporal evolution of $\mathrm{SO}_{2}$ emissions in northern Eurasia, along with atmospheric sulfur chemistry, is crucial for understanding and quantifying the impacts of anthropogenic activities and $\mathrm{SO}_{2}$ emissions on air quality, acidification as well as on regional and global climate.

\section{From system understanding to mitigation and adaptation strategies and decision-making}

Climate change and weather extremes are already affecting the living conditions of northern Eurasian societies. The vulnerability of the northern environments and societies, including their adaptive capacity and buffering thresholds, varies greatly depending on their current and future physical environment as well as their demographic structure and economic activities. The PEEX program as a whole is built on four pillars, namely (i) research, (ii) research infrastructure, (iii) impact on society, and (iv) knowledge transfer and capacity building. The scientific outcome of the first two pillars will be addressing the future state of the physical environment and its interactions and feedbacks with the demographic structure and economic activities in the Arctic-boreal system. Periodic PEEX assessments will be delivered for constructing mitigation and adaptation strategies of the Northern societies and for use of regional and governmental decision-making. The PEEX approach is applicable to China, when taking into 


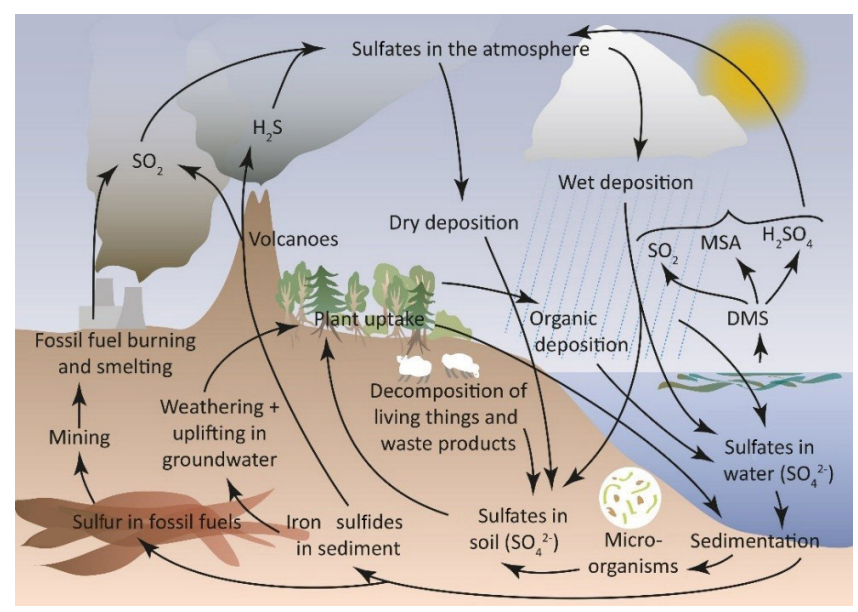

Figure 9. Schematic figure of the sulfur cycle.

account the specific geographical, climatological, and social characteristics of that region.

The integrative approach of the PEEX first two pillars provides both analytical and operational answers to our research questions, which can be utilized in solving interlinked grand challenges using pillars (iii) and (iv). These will also contribute to the ESS questions as a whole (see ESS questions: Schellnhuber et al., 2004). The implementation of the PEEX research agenda starts with process studies in the frame of three main topics determined for the land, atmosphere, aquatic, and social systems of the northern Eurasian region. The research approach is designed to answer the analytical questions on the major dynamical patters and feedback loops relevant to Earth system science in the northern context. The PEEX program has defined altogether 12 large-scale research questions for the 12 main topics in the northern Eurasian domain (Kulmala et al., 2016). At the same time, PEEX adheres to several operational ESS questions, including "what level of complexity and resolution have to be achieved in Earth System modelling?", "what are the best techniques for analyzing and predicting irregular events?", "what might be the most effective global strategy for generating, processing, and integrating relevant Earth system data sets?", and "what are the most appropriate methodologies for integrating natural science and social science knowledge?" (Schellnhuber et al., 2004).

In terms of the level of complexity and resolution in Earth system modelling, PEEX builds on a multi-scale modelling and observation approach originally introduced by Kulmala et al. (2009). PEEX will construct its own multi-scale modelling platform (Lappalainen et al., 2014). In terms of generating, processing and integrating relevant Earth system data sets, a detailed conceptual design of the PEEX research infrastructure (RI) will include a concept design of a coherent in situ observation network, coordinated use of remote sensing observations and standardized and harmonized data pro- cedures as well as a data system. One of the first tasks of PEEX-RI is to fill in the observational gap in atmospheric in situ and ground base remote sensing data in northern Eurasia, especially in Siberia. This approach is based not only on the coordination of existing observation activities (Alekseychik et al., 2016), but also on making plans for a new infrastructure needed. PEEX-RI development will be largely based on the SMEAR (Station for Measuring EcosystemAtmosphere Relations) concept (Kulmala et al., 2016), which has been developed by the University of Helsinki Division of Atmospheric Sciences together with Division of Forest Ecology starting from 1995 (Hari and Kulmala, 2005; Hari et al., 2016). The SMEAR concept provides a state-of-the-art foundation for establishing a PEEX observation system to be integrated into the global GEOSS data system. Furthermore, detailed design of greenhouse gas, aerosol, cloud, and trace gas measurements, and observation of biological activity will find synergies with the major European land-atmosphere observation infrastructures, such as ICOS (Integrated Carbon Observations System; a research infrastructure to determine the greenhouse gas balance of Europe and adjacent regions), ACTRIS (aerosols, clouds, and trace gases research infrastructure), GAW (Global Atmospheric Watch), and AnaEE (Infrastructure for Analysis and Experimentation on Ecosystems).

PEEX is interested in developing methodologies for integrating natural science and social science knowledge as part of the operational Earth sustainable system questions (Schellnhuber et al., 2004). The first-priority task in this case is to establish an integrated geographical information background (Ribeiro et al., 2009; Shvidenko et al., 2010; Skryzhevska et al., 2015). A common information background would be the first step serving the development of a common language of integrated studies. For example, we need spatially and temporally explicit descriptions of terrestrial ecosystems, landscapes, atmosphere, and hydrosphere. A common information background would be a unified base for the PEEX modelling platform and for the development of integrated modelling clusters, which could combine ecological, economic, and social dimensions. It could provide a historical background for the future trajectories of land cover, state and resilience of ecosystems, stability of landscapes, and dynamics of environmental indicators of environment. The already exiting Integrated Land Information System could be utilized here for combining all historical knowledge about the region and all scientific results obtained by past, current, and future studies across the region (Schepaschenko et al., 2011).

In addition to data services, PEEX is developing procedures for integrating and linking natural science and social science knowledge and data. As one example, we need to analyse data on emission sources together with population health risk factors, environment pollution, food security, drinking water quality, changes in the spreading areas of infectious diseases, and changes in the general epidemiological 


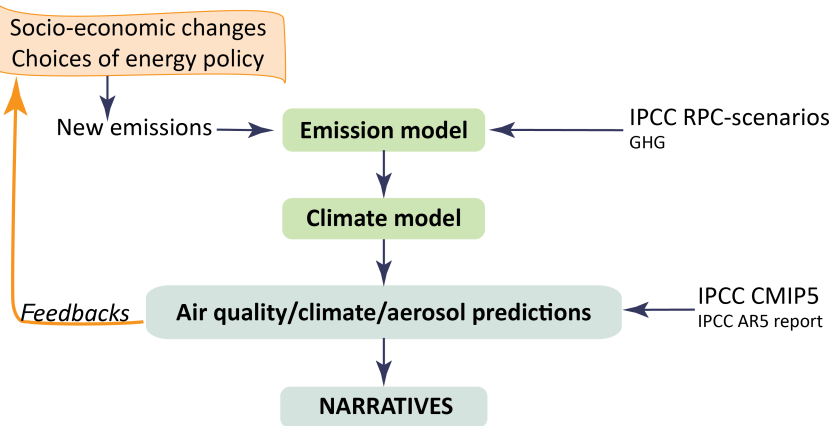

Figure 10. An example of the study approach to be implemented by PEEX for integrating natural science and social science knowledge and generating climate predictions and narratives of the northern regions.

situation (Bityukova and Kasimov, 2012; Malkhazova et al., 2013). Via novel multi-disciplinary data interfaces and data procedures, we are able to connect satellite observations with inverse modelling, provide fast updates to emission inventories, estimate the emission for the climate models, and, in the end, provide climate and air quality scenarios and the storylines of the future development of the Arctic-boreal region (Fig. 10).

In terms of strategic questions of the ESS, such as "what is the optimal mix of adaptation and mitigation measures to respond global change?" or "what is the structure of an effective and efficient system of global institutions and development of institutions?", PEEX is an active player in creating direct contacts with the stakeholders, so that its scientific information and services will receive an optimal impact on decision-making. Furthermore, the PEEX approach endorses the Earth System Manifesto (https://www.atm.helsinki.fi/ peex/images/manifesti_peex_ru_hub2.pdf), which addresses three strategic tasks: (i) construction of novel observation systems, (ii) finding consensus addressing necessary mitigation and adaptation actions in different parts of the world, and (iii) operational prerequisites for technological development to moderate the global change towards the sustainable Earth System. In this framework, PEEX will work closely with influential organizations, such as the Intergovernmental Panel for Climate Change (IPCC) delivering PEEX assessment of the Arctic-boreal region, the future earth acting as an Arctic-boreal hub, and the digital Earth via demonstrating novel methods for integrating in situ data with satellite observations.

\section{Data availability}

This paper is an overview of the current state of the art in selected fields relevant to system understanding of the arcticboreal regions. The results and conclusions presented in this paper are based on the already published peer reviewed pa- pers. Their underlying research data can be accessed via the information provided in the individual papers listed in the references.

Acknowledgements. The preparatory work of the PEEX approach, started in 2012, has been mainly based on the similar contribution of several European, Russian, and Chinese research institutes. The work presented here would not have been possible without the collaboration of the PEEX meetings participants. In 2012-2015 we have organized five PEEX meetings in Helsinki (2012, 2015), Moscow (2013), Hyytiälä (2013), and Saint Petersburg (2014), and the first PEEX Science conference in Helsinki, Finland, in February 2015. PEEX has also been active in a frame of international coordination activities and has as such been listed as GEOSS - Gold region project, IGBP-iLEAPS Arctic and boreal regional node, Digital Earth, Arctic Council - SAON Task, one of the main collaborators of the International Eurasian Academy of Sciences (IEAS) and Future Earth Arctic-boreal hub.

In addition, we would like acknowledge the support and funding from the following bodies: Academy of Finland Centre of Excellence (grant no. 272041), "International Working Groups, Markku Kulmala” grant by Finnish Cultural Foundation; ICOS 271878, ICOS-Finland no. 281255, ICOS-ERIC no. 281250 , nos. 259537, 218094, 255576, 286685, 280700, and 259537 funded by Academy of Finland; Beautiful Beijing project funded by TEKES, In GOS DEFROST, and CRAICC (no. 26060) and Nordforsk CRAICC-PEEX (amendment to contact 26060) funded by Nordforsk. "European-Russian Centre for cooperation in the Arctic and Sub-Arctic environmental and climate research" (EuRuCAS, grant 295068); Erasmus+ CBHE project ECOIMPACT 561975 funded by EU 7th Framework Program.

We thank many Russian projects, which have contributed to PEEX and have been granted by national funding organizations: Russian Mega-Grant no. 11.G34.31.0048 (University of Nizhny Novgorod), Russian Ministry of Education and Science Grants (unique project identifiers RFMEFI58614X0004 and RFMEFI58314X0003, ISR “AEROCOSMOS”, 2014-2016); Russian Science Foundation projects no. 15-17-20009 (University of Nizhny Novgorod) and no. 15-17-30009 (Faculty of Geography, Moscow University, 2015-2018), RFBR grant no. 14-05-91759 (ISR “AEROCOSMOS”, 2014-2016), Russian Science Foundation projects nos. 14-47-00049 (A. M. Obukhov Institute of Atmospheric Physics RAS, 2014-2016), 11.37.220.2016 (St.Petersburg State University) and 14-27-00083 (the Geochemical foundations of PEEX), 15-5554020 (SINP Moscow University, 2015-2016), and 14-17-00096 (Saint-Petersburg State University, 2014-2016). We also acknowledge Presidium of the Russian Academy of Sciences (program no. 4); the Branch of Geology, Geophysics and Mining Sciences of RAS (program no. 5); interdisciplinary integration projects of the Siberian Branch of the Russian Academy of Science nos. 35, 70, and 131; Russian Foundation for Basic Research (grants nos. 14-05-00526, 14-05-00590, 14-05-93108) and Russian Science Foundation project no. 14-17-00096 (Saint-Petersburg State University, 2014-2016). AARI thanks CNTP 1.5.3.2 and 1.5.3.4 of Roshydromet. Institute of Geography thanks Russian Academy of Sciences and Russian Science Foundation (project 1427-00133).

University of Tartu together with University of Life Sciences, Estonia, acknowledge the European Commission through European 
Regional Fund (the "Internationalization of Science Programme" project INSMEARIN, 10.1-6/13/1028, and the "Estonian Research Infrastructures Roadmap" project Estonian Environmental Observatory, 3.2.0304.11-0395). The University of Tartu, Estonia, acknowledges the institutional research funding IUT20-11 of the Estonian Ministry of Education and Research for its support for the development of SMEAR Estonia at Järvselja. Nansen Center, Norway, acknowledges the International Belmont Forum project "Anthropogenic Heat Islands in the Arctic - Windows to the Future of the Regional Climates, Ecosystems and Societies" no. $247468 / \mathrm{E} 10$.

Edited by: I. Salma

Reviewed by: two anonymous referees

\section{References}

Aaltonen, H., Pumpanen, J., Hakola, H., Vesala, T., Rasmus, S., and Bäck, J.: Snowpack concentrations and estimated fluxes of volatile organic compounds in a boreal forest, Biogeosciences, 9, 2033-2044, doi:10.5194/bg-9-2033-2012, 2012.

Achat, D. L., Bakker, M. R., Augusto, L., Derrien, D., Gallegos, N., Lashchinskiy, N., Milin, S., Nikitich, P., Raudina, T., Rusalimova, O., Zeller, B., and Barsukov, P.: Phosphorus status of soils from contrasting forested ecosystems in southwestern Siberia: effects of microbiological and physicochemical properties, Biogeosciences, 10, 733-752, doi:10.5194/bg-10-733-2013, 2013.

Alcamo, J., Mayerhofer, P., Guardans, R., van Harmelen, T., van Minnen, J., Onigkeit, J., Posch, M., and de Vries. B.: An integrated assessment of regional air pollution and climate change in Europe: findings of the AIR-CLIM Project, Environ. Sci. Policy, 5, 257-272, 2002.

Alekseychik, P., Lappalainen, H. K., Petäjä, T., Zaitseva, N., Arshinov, M., Shevchenko, V., Makshtas, A., Dubtsov, S., Mikhailov, E., Lapshina, E., Kirpotin, S., Kurbatova, Y., and Kulmala, M.: PEEX potential ground station network: an overview, J. Geography Environment, Sustainability, 2, 75-88, 2016.

Allen, C. D., Makalady A. K., Checjuini, H., Bachelet, D., McDowell, N., Vennetier, M., Kitzberger, T., Rigling, A., Breshears, D., Hogg, E. D., Gonzalez, P., Fensham, R., Zhang Z., Castro, J., Demidova, N., Lim, J.-M., Allard, G., Running, S. W., Semerci, A., and Cobb, N.: A global overview of drought and heat-induced tree mortality reveals emerging climate change risk for forests, Forest Ecol. Manag., 259, 660-684, 2010.

Allen, C. D., Breshears, D. D., and McDowel, N. G.: On underestimation of global vulnerability to tree mortality and forest dieoff from hotter drought in the Anthropocene, Ecosphere 6, 1-55, doi:10.1890/ES15-00203.1, 2015.

Andreae, M. O.: Ocean-atmosphere interactions in the global biogeochemical sulfur cycle, Mar. Chem., 30, 1-29, 1990.

Andreae, M. O.: Correlation between cloud condensation nuclei concentration and aerosol optical thickness in remote and polluted regions, Atmos. Chem. Phys., 9, 543-556, doi:10.5194/acp-9-543-2009, 2009.

Andreae, M. O. and Merlet, P.: Emission of trace gases and aerosols from biomass burning, Global Biogeochem. Cy., 15, 955-966, doi:10.1029/2000GB001382, 2001.
Anisimov, S. V., Mareev, E. A., and Bakastov, S. S.: On the generation and evolution of aeroelectric structures in the surface layer, J. Geophys. Res., 104, 14359-14368, 1999.

Anisimov, S. V., Mareev, E. A., Shikhova, N. M., and Dmitriev, E. M.: Universal spectra of electric field pulsations in the atmosphere, Geophys. Res. Lett., 29, 2217-2220, 2002.

Arashkevich, E. G., Flint, M. V., Nikishina, A. B., Pasternak, A. F., Timonin, A. G., Vasilieva, J. V., Mosharov, S. A., and Soloviev, K. A.: The role of zooplankton in transformation of organic matter in the Ob Estuary, on the shelf and in the deep regions of the Kara Sea, Oceanology, 50, 766-779, 2010.

Arctic Climate Impact Assessment (ACIA): Impacts of a Warming Arctic, Cambridge University Press, Cambridge, UK, ISBN 0521617782, 144 pp., 2004.

Arneth, A., Niinemets, Ü., Pressley, S., Bäck, J., Hari, P., Karl, T., Noe, S., Prentice, I. C., Serça, D., Hickler, T., Wolf, A., and Smith, B.: Process-based estimates of terrestrial ecosystem isoprene emissions: incorporating the effects of a direct $\mathrm{CO}_{2}$-isoprene interaction, Atmos. Chem. Phys., 7, 31-53, doi:10.5194/acp-7-31-2007, 2007.

Arneth, A., Harrison, S. P., Tsigaridis, K., Menon, S., Bartlein, P. J., Feichter, H., Korhola, A., Kulmala, M., O'Donell, D., Schurgers, G., Sorvari, S., Vesala, T., and Zaehle, S.: Terrestrial biogeochemical feedbacks in the climate system: from past to future, Nat. Geosci., 3, 525-532, 2010.

Arneth, A., Olin, S., Makkonen, R., Paasonen, P., Holst, T., Kajos, M., Kulmala, M., Maximov, T., Miller, P. A., and Schurgers, G.: Future biogeochemical forcing in Eastern Siberia: cooling or warming?, Atmos. Chem. Phys. Discuss., 14, 19149-19179, doi:10.5194/acpd-14-19149-2014, 2014.

Arnold, S. R., Emmons, L. K., Monks, S. A., Law, K. S., Ridley, D. A., Turquety, S., Tilmes, S., Thomas, J. L., Bouarar, I., Flemming, J., Huijnen, V., Mao, J., Duncan, B. N., Steenrod, S., Yoshida, Y., Langner, J., and Long, Y.: Biomass burning influence on high-latitude tropospheric ozone and reactive nitrogen in summer 2008: a multi-model analysis based on POLMIP simulations, Atmos. Chem. Phys., 15, 6047-6068, doi:10.5194/acp15-6047-2015, 2015.

Arshinov, M., Yu, M., Belan, B. D., Kozlov, A. V., Antokhin, P. N., Davydov, D. K., and Arshinova V. G.: Continuous measurements of aerosol size distribution at two Siberian stations: new particle formation bursts, in: European Aerosol Conference, Granada, Spain, 2-7 September 2012, A-WG01S1P25, 2012.

Asmi, E., Kivekäs, N., Kerminen, V.-M., Komppula, M., Hyvärinen, A.-P., Hatakka, J., Viisanen, Y., and Lihavainen, H.: Secondary new particle formation in Northern Finland Pallas site between the years 2000 and 2010, Atmos. Chem. Phys., 11, 12959-12972, doi:10.5194/acp-11-12959-2011, 2011.

Asmi, E., Kondratyev, V., Brus, D., Laurila, T., Lihavainen, H., Backman, J., Vakkari, V., Aurela, M., Hatakka, J., Viisanen, Y., Uttal, T., Ivakhov, V., and Makshtas, A.: Aerosol size distribution seasonal characteristics measured in Tiksi, Russian Arctic, Supplement, Atmos. Chem. Phys., 16, 1271-1287, doi:10.5194/acp16-1271-2016, 2016.

Atlaskina, K., Berninger, F., and de Leeuw, G.: Satellite observations of changes in snow-covered land surface albedo during spring in the Northern Hemisphere, The Cryosphere, 9, 18791893, doi:10.5194/tc-9-1879-2015, 2015. 
Bäck, J., Aaltonen, H., Hellen, H., Kajos, M. K., Patokoski, J., Taipale, R., Pumpanen, J., and Heinonsalo, J.: Variable emissions of microbial volatile organic compounds (MVOCs) from root-associated fungi isolated from Scots pine, Atmos. Environ., 44, 3651-3659, doi:10.1016/j.atmosenv.2010.06.042, 2010.

Baklanov, A. A., Penenko, V. A., Mahura, A. G., Vinogradova, A. A., Elansky, N. F., Tsvetova, E. A., Rigina, O., Yu, O., Maksimenkov, L. O., Nuterman, R. B., Pogarskii, F. A., and Zakey, A.: Aspects of atmospheric pollution in Siberia, in: Regional Environmental Changes in Siberia and Their Global Consequences, edited by: Gutman, G. and Groisman, P., Springer, Dordrecht, the Netherlands, 303-346, 2013.

Bala, G., Krishna, S., Narayanappa, D., Cao, L., Caldeira, K., and Nemani, R.: An estimate of equilibrium sensitivity of global terrestrial carbon cycle using NCAR CCSM4, Clim. Dynam., 40, 1671-1686, 2013.

Ballantyne, A. P., Alden, C. B., Miller, J. B., Tans, P. P., and White, J. W. C.: Increase in observed net carbon dioxide uptake by land and oceans during the past 50 years, Nature, 488, 70-72, doi:10.1038/nature11299, 2012.

Bastviken, D., Tranvik, L. J., Downing, J. A., Crill, P. M., and Enrich-Prest, A.: Freshwater methane emissions offset the continental carbon sink, Science, 331, 50 pp., doi:10.1126/science.1196808, 2011.

Battarbee, R. W., Patrick, S., Kernan, M., Psenner, R., Thies, H., Grimalt, J., Rosseland, B. O., Wathne, B., Catalan, J., Mosello, R., Lami, A., Livingstone, D., Stuchlik, E., Straskrabova, V., and Raddum, G.: High mountain lakes and atmospherically transported pollutants, in: Global Change and Mountain Regions, edited by: Huber, U. M., Bugmann, H. K. M., and Reasoner, M. A., Springer, Dordrecht, the Netherlands, 2005.

Bauer, P., Thorpe, A., and Brunet, G.: The quiet revolution of numerical weather prediction, Nature, 525, 47-55, doi:10.1038/nature14956, 2015.

Bauerle, W. L., Bauerlea, W. L., Orenc, R., Wayc, D. A., Qianc, S. S., Stoyf, P. C., Thorntong, P. E., Bowdena, J. D., Hoffmanh, F. M., and Reynoldsi, R. F.: Photoperiodic regulation of the seasonal pattern of photosynthetic capacity and the implications for carbon cycling, P. Natl. Acad. Sci., 109, 8612-8617, doi:10.1073/pnas.1119131109, 2012.

Berchet, A., Paris, J.-D., Ancellet, G., Law, K. S., Stohl, A., Nédélec, P., Arshinov, M., Yu, M., Belan, B. D., and Ciais, P.: Tropospheric ozone over Siberia in spring 2010: remote influences and stratospheric intrusion, Tellus B, 65, 19688, doi:10.3402/tellusb.v65i0.19688, 2013.

Berchet, A., Pison, I., Chevallier, F., Paris, J.-D., Bousquet, P., Bonne, J.-L., Arshinov, M. Y., Belan, B. D., Cressot, C., Davydov, D. K., Dlugokencky, E. J., Fofonov, A. V., Galanin, A., Lavric, J., Machida, T., Parker, R., Sasakawa, M., Spahni, R., Stocker, B. D., and Winderlich, J.: Natural and anthropogenic methane fluxes in Eurasia: a mesoscale quantification by generalized atmospheric inversion, Biogeosciences, 12, 5393-5414, doi:10.5194/bg-12-5393-2015, 2015.

Bergen, K. M., Hitztaler, S. K., Kharuk, V. I., Krankina, O. N., Loboda, T. V., Zhao, T., Shugart, H. H., and Sun, G.: Human dimensions of environmental change in Siberia, in: Regional Environmental Changes in Siberia and Their Global Consequences, edited by: Groisman, P. Y. and Gutman, G., Springer Science + Business, Media, Dortrecht, the Netherlands, 2013.
Berner, L. T., Beck, P. S. A., Bunn A. G., and Goetz, S. J.: Plant response to climate change along the forest-tundra ecotone in northeastern Siberia, Glob. Change Biol., 19, 3449-3462, 2013.

Berry, P. A. M., Garlick, J. D., Freeman, J. A., and Mathers, E. L.: Global inland water monitoring from multi-mission altimetry, Geophys. Res. Lett., 32, L16401, doi:10.1029/2005GL022814, 2005.

Bityukova, V. R. and Kasimov, N. S.: Atmospheric pollution of Russia's cities: assessment of emissions and immissions based on statistical data, Geofizika, 29, 53-67, 2012.

Bityukova, V. R., Kasimov, N. S., and Vlasov, D. V.: Environmental portrait of Russian cities, J. Ecol. Ind. Russ., 4, 6-18, 2010.

Bluhm, B. A., Gebruk, A. V., Gradinger, R., Hopcroft, R. R., Huettmann, F., Kosobokova, K. N., Sirenko, B. I., and Weslawski, J. M.: Arctic Marine Biodiversity: An Update of Species Richness and Examples of Biodiversity Change, Oceanography, 24, 232-248, 2011.

Bobbink, R., Hicks, K., Galloway, J., Spranger, T., Alkemade, R., Ashmore, M., Bustamante, M., Cinderby, S., Davidson, E., Dentener, F., Emmett, B., Erisman, J.W., Fenn, M., Gilliam, F., Nordin, A., Pardo, L., and de Vries, W.: Global assessment of nitrogen deposition effects on terrestrial plant diversity: a synthesis, Ecol. Appl., 20, 30-59, 2010.

Bodman, R. W., Rayner, P. J., and Karoly D. J.: Uncertainty in temperature projections reduced using carbon cycle and climate observations, Nat. Clim. Change, 3, 725-729, 2013.

Bolin, B., Ciais, P., Cramer, W., Jarvis, P., Kheshgi, H., Nobre, C., Semenov, S., and Steffen, W.: Global perspective, in: Land use, land-use change, and forestry. A special report of the IPCC, edited by: Watson, R. T, Noble, I. R., Bolin, B., Ravindranath, N. H., Verardo D. J., and Dokken, D. J., Cambridge University Press, Cambridge, UK, 23-51, 2000.

Bond, T. C., Doherty, S. J., Fahey, D. W., Foster, P. M., Berntsen, T., DeAngelo, B. J., Flanner, M. G., Ghan, S., Kärcher, B., Kock, D., Kinne, S., Kondo, Y., Quinn, P. K., Sarofilm, M. C., Schulz, M., Venkataram, C., Zhang, H., Zhang, S., Belloiin, N., Guttukunda, S. K., Hopke, P. K., Jacobson, M. Z., Kaiser, J. W., Klimont Z., Lohmann, U., Schwarz, J. P., Shindell, D., Storelmo, T., Warren, S. G., and Zender, C. S.: Bounding the role of black carbon in the climate system: A scientific assessment, J. Geophys. Res., 118, 5380-5552, doi:10.1002/jgrd.50171, 2013.

Bondur, V. G.: Aerospace Methods and Technologies for Monitoring Oil and Gas Areas and Facilities, Izv. Atmos. Ocean. Phy.+, 47, 1007-1018, 2011a.

Bondur, V. G.: Satellite Monitoring of Wildfires during the Anomalous Heat Wave of 2010 in Russia, Izv. Atmos. Ocean. Phy.+, 47, 1039-1048, $2011 \mathrm{~b}$.

Bondur, V. G.: Modern Approaches to Processing Large Hyperspectral and Multispectral Aerospace Data Flows, Izv. Atmos. Ocean. Phy.+, 50, 840-852, doi:10.1134/S0001433814090060, 2014.

Bondur, V. G.: Space-borne monitoring of trace gas and aerosol emissions during wildfires in Russia, Issledovanie Zemli iz Cosmosa, 6, 3-19, 2015.

Bondur, V. G. and Ginsburg, A. S.: Emissions of carbon-containing gases and aerosols resulted from wildfires in Russia according to space-borne monitoring data, Dokl. Akad. Nauk+., 466, 473477, 2016.

Bondur, V. G. and Vorobev, V. E.: Satellite monitoring of impact Arctic regions, Izv. Atmos. Ocean. Phy.+, 51, 949-968, 2015. 
Bony, S., Stevens, B., Frierson, D. M. W., Jakob, C., Kageyama, M., Pincus, R., Shepherd, T. G., Sherwood, S. C., Siebesma, A. P., Sobel, A. H., Watanabe, M., and Webb, M. J.: Clouds, circulation and climate sensitivity, Nat. Geosci., 8, 261-268, doi:10.1038/ngeo2398, 2015.

Boyle, J. F., Mackay, A. W., Rose, N. L., Flower, R. J., and Appleby, P. G.: Sediment heavy metal records in Lake Baikal: natural and anthropogenic sources, J. Palaeolimnol., 20, 135-150, 1998.

Brunello, A. J., Molotov, V. C., Dugherkhuu, B., Goldman, C., Khamaganova, E., Strijhova, T., and Sigman, R.: Lake Baikal. Experiences and Lessons Learned Brief, Tahoe-Baikal Institute, South Lake Tahoe, CA, USA, 2006.

Burrows, J. P., Platt, U., and Borrel, P. (Eds.): The Remote Sensing of Tropospheric Composition from Space, Springer-Verlag Berlin Heidelberg, Germany, 359-313, doi:10.1007/978-3-64214791-3, 2011.

Byambaa, B. and Todo, Y.: Technological Impact of Placer Gold Mine on Water Quality: Case of Tuul River Valley in the Zaamar Goldfield, Mongolia, World Academy of Science, Water Resour. Manag., 145, 309-318, doi:10.2495/WRM110261, 2011.

Canfield, D. E., Glazer, A. N., and Falkowski, P. G.: The Evolution and Future of Earth's Nitrogen Cycle, Science, 330, 192-196, doi:10.1126/science.1186120, 2010.

Carslaw, K. S., Boucher, O., Spracklen, D. V., Mann, G. W., Rae, J. G. L., Woodward, S., and Kulmala, M.: A review of natural aerosol interactions and feedbacks within the Earth system, Atmos. Chem. Phys., 10, 1701-1737, doi:10.5194/acp-10-17012010, 2010.

Cavalieri, D. J. and Parkinson, C. L.: Arctic sea ice variability and trends, 1979-2010, The Cryosphere, 6, 881-889, doi:10.5194/tc6-881-2012, 2012.

Charlson, R. J., Lovelock, J. E., Andreae, M. O., and Warren, S. G.: Oceanic phytoplankton, atmospheric sulphur, cloud albedo and climate, Nature, 326, 655-661, 1987.

Cheng, B., Zhang, Z., Vihma, T., Johansson, M., Bian, L., Li, Z., and Wu, H.: Model experiments on snow and ice thermodynamics in the Arctic Ocean with CHINARE2003 data, J. Geophys. Res., 113, C09020, doi:10.1029/2007JC004654, 2008.

Chernokulsky, A. V. and Mokhov, I. I.: Climatology of total cloudiness in the Arctic: An intercomparison of observations and reanalyses, Adv. Meteorol., 2012, 542093, doi:10.1155/2012/542093, 2012.

Chi, X., Winderlich, J., Mayer, J.-C., Panov, A. V., Heimann, M., Birmili, W., Heintzenberg, J., Cheng, Y., and Andreae, M. O.: Long-term measurements of aerosol and carbon monoxide at the ZOTTO tall tower to characterize polluted and pristine air in the Siberian taiga, Atmos. Chem. Phys., 13, 12271-12298, doi:10.5194/acp-13-12271-2013, 2013.

Ciais, P., Janssens, I., Shvidenko, A., Wirth, C., Malhi, Y., Grace, J., Schulze, E. D., Heimann, M., Phillips, O., and Dolman, A. J.: The potential for rising $\mathrm{CO}_{2}$ to account for the observed uptake of carbon by tropical, temperate, and boreal forests biome, in: The Carbon Budget of Forest Biomes, edited by: Griffiths, $\mathrm{H}$. and Jarvis, P. J., Garland Science, BIOS Scientific Publishers, 109-149, 2005.

Cohen, J., Screen, J. A., Furtado, J. C., Barlow, M., Whittleston, D., Coumou, D., Francis, J., Dethloff, K., Entekhabi, D., Overland, J., and Jones, J.: Recent Arctic amplification and extreme mid-latitude weather, Nat. Geosci., 7, 627-637, doi:10.1038/ngeo2234, 2014.

Conard, S. G., Sukhinin, A. I., Stocks B. J., Cahoon, D. R., Davidenko, E. P., and Ivanova, G. A.: Determining effects of area burned and fire severity on carbon cycling and emissions in Siberia, Climatic Change, 55, 197-211, 2002.

Conley, D. J., Paerl, H. Q., Howarth, R. W., Boesch, D. F., Seitzinger, S. P., Havens, K. E., Lancelot, C., and Likens, G. E.: Controlling eutrophication: nitrogen and phosphorus, Science, 323, 1014-1015, 2009.

Crutzen, P. J., Elansky, N. F., Hahn, M., Golitsyn, G. S., Benninkmeijer, C. A. M., Scharffe, D. H., Belikov, I. B., Maiss, M., Bergamaschi, P., Röckmann, T., Grisenko A. M., and Sevostyanov, V. M.: Trace gas measurements between Moscow and Vladivistok using the Trans-Siberian Railroad, J. Atmos. Chem., 29, 179-194, 1998.

Dal Maso, M., Sogacheva, L., Aalto, P. P., Riipinen, I., Komppula, M., Tunved, P., Korhonen, L., Suur-Uski, V., Hirsikko, A., Kurtén, T., Kerminen, V.-M., Lihavainen, H., Viisanen, Y., Hansson, H.-C., and Kulmala, M.: Aerosol size distribution measurements at four Nordic field stations: identification, analysis and trajectory analysis of new particle formation bursts, Tellus, 59B, 350-361, 2007.

Davy, R. and Esau, I.: Global climate models' bias in surface temperature trends and variability, Environ. Res. Lett., 9, 114024, doi:10.1088/1748-9326/9/11/114024, 2014.

Davy, R. and Esau, I.: Differences in the efficacy of climate forcings explained by variations in atmospheric boundary layer depth, Nat. Commun., 7, 11690, doi:10.1038/ncomms11690, 2016.

de Laat, A. T. J., van der A, R. J., and van Weele, M.: Evaluation of tropospheric ozone columns derived from assimilated GOME ozone profile observations, Atmos. Chem. Phys., 9, 8105-8120, doi:10.5194/acp-9-8105-2009, 2009.

de Leeuw, G., Andreas, E. L., Anguelova, M. D., Fairall, C. W., Lewis, E. R., O'Dowd, C., Schulz, M., and Schwartz, S. E.: Production flux of sea spray aerosol, Rev. Geophys., 49, RG2001, doi:10.1029/2010RG000349, 2011.

de Leeuw, G., Holzer-Popp, T., Bevan, S., Davies, W., Descloitres, J., Grainger, R. G., Griesfeller, J., Heckel, A., Kinne, S., Klüser, L., Kolmonen, P., Litvinov, P., Martynenko, D., North, P. J. R., Ovigneur, B., Pascal, N., Poulsen, C., Ramon, D., Schulz, M., Siddans, R., Sogacheva, L., Tanré, D., Thomas, G. E., Virtanen, T. H., von Hoyningen Huene, W., Vountas, M., and Pinnock, S.: Evaluation of seven European aerosol optical depth retrieval algorithms for climate analysis, Remote Sens. Environ., 162, 295315, doi:10.1016/j.rse.2013.04.023, 2015.

Dentener, F., Drevet, J., Lamarque, J. F., Bey, I., Eickhout, B., Fiore, A. M., Hauglustaine, D., Horowitz, L. W., Krol, M., Kulshrestha, U. C., Lawrence, M., Galy-Lacaux, C., Rast, S., Shindell, D., Stevenson, D., Noije, T. V., Atherton, C., Bell, N., Bergman, D., Butler, T., Cofala, J., Collins, B., Doherty, R., Ellingsen, K., Galloway, J., Gauss, M., Montanaro, V., Müller, J. F., Pitari, G., Rodriguez, J., Sanderson, M., Solmon, F., Strahan, S., Schultz, M., Sudo, K., Szopa, S., and Wild, O.: Nitrogen and sulfur deposition on regional and global scales: a multimodel evaluation, Global Biogeochem. Cy., 20, GB4003, doi:10.1029/2005GB002672, 2006.

Ding, A. J., Wang, T., Thouret, V., Cammas, J.-P., and Nédélec, P.: Tropospheric ozone climatology over Beijing: analysis of aircraft 
data from the MOZAIC program, Atmos. Chem. Phys., 8, 1-13, doi:10.5194/acp-8-1-2008, 2008.

Ding, A. J., Wang, T., Xue, L. K., Gao, J., Stohl, A., Lei, H. C., Jin, D. Z., Ren, Y., Wang, X. Z., Wei, X. L., Qi, Y. B., Liu, J., and Zhang, X. Q.: Transport of north China air pollution by mid-latitude cyclones: Case study of aircraft measurements in summer 2007, J. Geophys. Res., 114, D08304, doi:10.1029/2009JD012339, 2009.

Ding, A. J., Fu, C. B., Yang, X. Q., Sun, J. N., Petäjä, T., Kerminen, V.-M., Wang, T., Xie, Y., Herrmann, E., Zheng, L. F., Nie, W., Liu, Q., Wei, X. L., and Kulmala, M.: Intense atmospheric pollution modifies weather: a case of mixed biomass burning with fossil fuel combustion pollution in eastern China, Atmos. Chem. Phys., 13, 10545-10554, doi:10.5194/acp-1310545-2013, 2013a.

Ding, A. J., Fu, C. B., Yang, X. Q., Sun, J. N., Zheng, L. F., Xie, Y. N., Herrmann, E., Nie, W., Petäjä, T., Kerminen, V.-M., and Kulmala, M.: Ozone and fine particle in the western Yangtze River Delta: an overview of $1 \mathrm{yr}$ data at the SORPES station, Atmos. Chem. Phys., 13, 5813-5830, doi:10.5194/acp-13-58132013, 2013b.

Dolezalek, H., Reiter, R., and Landsberg, H. E. (Eds.): Electrical Processes in Atmospheres, Proceedings of the Fifth International Conference on Atmospheric Electricity, GarmischPartenkirchen, Germany, 2-7 September 1974, Dr. Dietrich Steinkopff Verlag, Darmstadt, Germany, 1976.

Dolman, A. J., Shvidenko, A., Schepaschenko, D., Ciais, P., Tchebakova, N., Chen, T., van der Molen, M. K., Belelli Marchesini, L., Maximov, T. C., Maksyutov, S., and Schulze, E.-D.: An estimate of the terrestrial carbon budget of Russia using inventory-based, eddy covariance and inversion methods, Biogeosciences, 9, 5323-5340, doi:10.5194/bg-9-5323-2012, 2012.

Domysheva, V., Panchenko, M., Pestunov, D., and Sakirko M.: Air-Water Carbon Dioxide Exchange in the Littoral Zone of Lake Baikal (Ice-Free Period), Int. J. Geosci., 4, 1339-1345, doi:10.4236/ijg.2013.410130, 2013.

Dooley, S. R. and Treseder, K. K.: The effect of fire on microbial biomass: a meta-analysis of field studies, Biogeochemistry, 109, 49-61, doi:10.1007/s10533-011-9633-8, 2012.

Döscher, R., Vihma, T., and Maksimovich, E.: Recent advances in understanding the Arctic climate system state and change from a sea ice perspective: a review, Atmos. Chem. Phys., 14, 1357113600, doi:10.5194/acp-14-13571-2014, 2014.

Drake, J. E., Gallet-Budynek, A., Hofmockel, K. S., Bernhardt, E., Billings, S., Jackson, R. B., Johnsen, K. S., Lichter, J., McCarthy, H. R., McCormack, L., Moore, D., Oren, R., Palmroth, S., Phillips, R. P., Pippen, J. S., Pritchard, S., Treseder, K. K., Schlesinger, W. H., DeLucia, E., and Finzi, A. C.: Increases in the flux of carbon belowground stimulate nitrogen uptake and sustain the long-term enhancement of forest productivity under elevated $\mathrm{CO}_{2}$, Ecol. Lett., 14, 349-357, doi:10.1111/j.14610248.2011.01593.x, 2011.

Ducklow, H., Steinber, D. K., and Buesseler, K. O.: Upper ocean carbon export and the biological pump, Oceanography, 14, 5058, 2001.

Eckhardt, S., Quennehen, B., Olivié, D. J. L., Berntsen, T. K., Cherian, R., Christensen, J. H., Collins, W., Crepinsek, S., Daskalakis, N., Flanner, M., Herber, A., Heyes, C., Hodnebrog, Ø., Huang, L., Kanakidou, M., Klimont, Z., Langner, J., Law,
K. S., Lund, M. T., Mahmood, R., Massling, A., Myriokefalitakis, S., Nielsen, I. E., Nøjgaard, J. K., Quaas, J., Quinn, P. K., Raut, J.-C., Rumbold, S. T., Schulz, M., Sharma, S., Skeie, R. B., Skov, H., Uttal, T., von Salzen, K., and Stohl, A.: Current model capabilities for simulating black carbon and sulfate concentrations in the Arctic atmosphere: a multi-model evaluation using a comprehensive measurement data set, Atmos. Chem. Phys., 15, 9413-9433, doi:10.5194/acp-15-9413-2015, 2015.

Elansky, N. F., Belikov, I. B., Lavrova, O. V., Skorokhod, A. I., Shumsky, R. A., Brenninkmeijer, C. A. M., and Tarasova, O. A.: Train-Based Platform for Observations of the Atmosphere Composition (TROICA Project), chap. 8 in: Air PollutionMonitoring, Modelling and Health, edited by: Khare, M., Tech., 386, 175-196, doi:10.5772/1801, 2012.

Elberling, B., Christiansen, H. H., and Hansen, B. U.: High nitrous oxide production from thawing permafrost, Nat. Geosci., 3, 332335, 2010.

Elbert, W., Weber, B., Burrows, S., Steinkamp, J., Budel, B., Andreae, M. O., and Pöschl, U.: Contribution of cryptogamic covers to the global cycles of carbon and nitrogen, Nat. Geosci., 5 , 459-462, 2012.

Emmons, L. K., Arnold, S. R., Monks, S. A., Huijnen, V., Tilmes, S., Law, K. S., Thomas, J. L., Raut, J.-C., Bouarar, I., Turquety, S., Long, Y., Duncan, B., Steenrod, S., Strode, S., Flemming, J., Mao, J., Langner, J., Thompson, A. M., Tarasick, D., Apel, E. C., Blake, D. R., Cohen, R. C., Dibb, J., Diskin, G. S., Fried, A., Hall, S. R., Huey, L. G., Weinheimer, A. J., Wisthaler, A., Mikoviny, T., Nowak, J., Peischl, J., Roberts, J. M., Ryerson, T., Warneke, C., and Helmig, D.: The POLARCAT Model Intercomparison Project (POLMIP): overview and evaluation with observations, Atmos. Chem. Phys., 15, 6721-6744, doi:10.5194/acp15-6721-2015, 2015.

Erisman, J. W., Grinsven, H. V., Grizzetti, B., Bouraoui, F., and Powlson, D.: The European nitrogen problem in a global perspective, in: The European Nitrogen Assessment, edited by: Sutton, M. A., Howard, C. M., Erisman, J. W., Billen, G., Bleeker, A., Grennfelt, P., and Hansen, J., Cambridge University Press, Cambridge, UK, 2011.

Esau, I., Davy, R., and Outten, S.: Complementary explanation of temperature response in the lower atmosphere, Environ. Res. Lett., 7, 044026, doi:10.1088/1748-9326/7/4/044026, 2012.

Esau, I., Miles, V. V., Davy, R., Miles, M. W., and Kurchatova, A.: Trends in normalized difference vegetation index (NDVI) associated with urban development in northern West Siberia, Atmos. Chem. Phys., 16, 9563-9577, doi:10.5194/acp-16-95632016, 2016.

Esau, I. N. and Chernokulsky, A. V.: Convective Cloud Fields in the Atlantic Sector of the Arctic: Satellite and Ground-Based Observations, Izv. Atmos. Ocean. Phy.+, 51, 1007-1020, 2015.

Faubert, P., Tiiva, P., Michelsen, A., Rinnan, Å., Ro-Poulsen, H., and Rinnan, R.: The shift in plant species composition in a subarctic mountain birch forest floor due to climate change would modify the biogenic volatile organic compound emission profile, Plant Soil, 352, 199-215, doi:10.1007/s11104-011-0989-2, 2012.

Fehsenfeld, F. C., Fehsenfeld, F. C., Ancellet, G., Bates, T. S., Goldstein, A. H., Hardesty, M., Honrath, R., Law, K. S., Lewis, A. C., Leaitch, R., McKeen, S., Meagher, J., Parrish, D. D., P. Pszenny, A. A., Russell, P. B., Schlager, H., Seinfeld, J., Talbot, R., and 
Zbinden, R.: International Consortium for Atmospheric Research on Transport and Transformation (ICARTT): North America to Europe-Overview of the 2004 summer field study, J. Geophys. Res., 111, D23S01, doi:10.1029/2006JD007829, 2006.

Feuchtmayr, H., Moran, R., Hatton, K., Cannor, L., Yeyes, T., Harley, J., and Arkinson, D.: Global warming and eutrophication: effects on water chemistry and autotrophic communities in experimental hypertrophic shallow lake mesocosms, J. Appl. Ecol., 46, 713-723, 2009.

Fisher, J. B., Tu, K. P., and Baldocchi, D. D.: Global estimates of the land-atmosphere water flux based on monthly AVHRR and ISLSCP-II data, validated at 16 FLUXNET sites, Remote Sens. Environ., 112, 901-919, 2008.

Flanner, M. G., Zender, C. S., Hess, P. G., Mahowald, N. M., Painter, T. H., Ramanathan, V., and Rasch, P. J.: Springtime warming and reduced snow cover from carbonaceous particles, Atmos. Chem. Phys., 9, 2481-2497, doi:10.5194/acp-9-24812009, 2009.

Flanner, M. G., Shell, K. M., Barlage, M., Perovich, D. K., and Tschudi, M. A.: Radiative forcing and albedo feedback from the Northern Hemisphere cryosphere between 1979 and 2008, Nat. Geosci., 4, 151-155, 2011.

Flannigan, M. D., Stocks, B. J., Turetsky, M. R., and Wotton, B. M.: Impact of climate change on fire activity and fire management in the circumboreal forest, Glob. Change Biol., 15, 549-560, 2009.

Flint, M. V. (Ed.): Esosystem of the Kara Sea, Oceanology, 50, 637820,2010

Garmaev, E. Z. and Khristoforov, A. V.: Water resources of Rivers in Lake Baikal Basin: Principles of their use and prodection Novosibirsk (in Russia), GEO, 2010.

Gauthier, S., Bernier, P., Kuuluvainen, T., Shvidenko, A. Z., and Schepaschenko, D. G.: Boreal forest health and global change, Science, 349, 819-822, 2015.

Gewehr, S., Drobyshev, I., Berninger, F., and Bergerona, Y.: Soil characteristics mediate the distribution and response of boreal trees to climatic variability, Can. J. Forest Res., 44, 487-498, doi:10.1139/cjfr-2013-0481, 2014.

Glezer, O. B.: Population and Its Settlement Pattern, in: Space, Population, and Economics of Yugra, Socioeconomic Transformation of the Khanty-Mansi Autonomous Okrug, edited by: Artobolevsky, S. S. and Glezer, O. B., Ekonomist, 169-191, 2007a (in Russian).

Glezer, O. B.: The Development of the North Abroad: Experience and Lessons, J. Environ. Plann. Man., 4, 62-76, 2007 b (in Russian).

Glindemann, D., Edwards, M., Liu, J., and Kuschk, P.: Phosphine in soils, sludges, biogases and atmospheric implications - a review, Ecol. Eng., 24, 457-463, 2005.

Global Forest Watch:, Atlas of Russia's Intact Forest Landscapes, Russia 2002, edited by: Laestadius, L., Dobrynin, D., Isaev, A., Karpachevskiy, M., Laestadious, L., Potapov, P., Purekhovskiy, A., Turubanova, S., and Yaroshenko, A., 72 pp., Moscow, Russia, 2002.

Goldenson, N., Doherty, S. J., Bitz, C. M., Holland, M. M., Light, B., and Conley, A. J.: Arctic climate response to forcing from light-absorbing particles in snow and sea ice in CESM, Atmos. Chem. Phys., 12, 7903-7920, doi:10.5194/acp-12-7903-2012, 2012.
Granier, C., Bessagnet, B., Bond, T., and D’Angiola, A.: Evolution of anthropogenic and biomass burning emissions of air pollutants at global and regional scales during the 1980-2010 periods, Climatic Change, 109, 163-190, 2011.

Granina, L. Z.: The chemical budget of Lake Baikal - A review, Limnol. Oceanogr., 42, 373-378, 1997.

Groisman, P. Y., Gutman, G., Shvidenko, A. Z., Bergen, K., Baklanov, A. A., and Stackhouse Jr., P. W.: Introduction - Regional features of Siberia, in: Regional Environmental Changes in Siberia and Their Global Consequences, edited by: Groisman, P. Y. and Gutman, G., Springer Science + Business Media, Dortrecht, the Netherlands, 1-17, 2013.

Gromtsev, A.: Natural Disturbance Dynamics in Boreal Forests of European Russian: a Review, Silva Fenn., 36, 41-55, 2002.

Grote, R. and Niinemets, Ü.: Modeling volatile isoprenoid emissions - a story with split ends, Plant Biol., 10, 8-28, 2008.

Gruber, N. and Galloway, J. N.: An Earth-system perspective of the global nitrogen cycle, Nature, 451, 293-296, 2008.

Gurney, K. R., Rachel, M., Law, R. M., Denning, A. S., Rayner, P. J., Baker, D., Bousquet, P., Bruhwiler, L., Chen, Y.-H., Ciais, P., Fan, S., Fung, I. Y., Gloor, M., Heimann, M., Higuchi, K., John, J., Maki, T., Maksyutov, S., Masarie, K., Peylin, P., Prather, M., Pak, B. C., Randerson, J., Sarmiento, J., Taguchi, S., Takahashi, T., and Yuen, C.-W.: Towards robust regional estimates of $\mathrm{CO}_{2}$ sources and sinks using atmospheric transport models, Nature, 415, 626-630, 2002.

Gustafsson, Ö., van Dongen, B. E., Vonk, J. E., Dudarev, O. V., and Semiletov, I. P.: Widespread release of old carbon across the Siberian Arctic echoed by its large rivers, Biogeosciences, 8, 1737-1743, doi:10.5194/bg-8-1737-2011, 2011.

Harden, J. W., Trumbore, S. E., Stocks, B. J., Hirsch, A., Gower, S. T., O'Neill, K. P., and Kasischke, E. S.: The role of fire in the boreal carbon budget, Glob. Change Biol., 6, 174-184, doi:10.1046/j.1365-2486.2000.06019.x, 2000.

Hari, P. and Kulmala, M.: Stations for Measuring Ecosystem - Atmosphere Relations (SMEAR II), Boreal Environ. Res., 10, 315322, 2005.

Hari, P., Petäjä, T., Bäck, J., Kerminen, V.-M., Lappalainen, H. K., Vihma, T., Laurila, T., Viisanen, Y., Vesala, T., and Kulmala, M.: Conceptual design of a measurement network of the global change, Atmos. Chem. Phys., 16, 1017-1028, doi:10.5194/acp16-1017-2016, 2016.

Heald, C. L. and Spracklen, D. V.: Atmospheric budget of primary biological aerosol particles from fungal spores, Geophys. Res Lett., 36, L09806, doi:10.1029/2009GL037493, 2009.

Heikkinen, J. E. P., Virtanen, T., Huttunen, J. T., Elsakov, V., and Martikainen, P. J.: Carbon balance in East European tundra, Global Biogeochem. Cy., 18, GB1023, doi:10.1029/2003GB002054, 2004.

Heimann, M. and Reichstein, M.: Terrestrial ecosystem carbon dynamics and climate feedbacks, Nature, 451, 289-292, doi:10.1038/nature06591, 2008.

Heimann, M., Schulze, E.-D., Winderlich, J., Andreae, M. O., Chi, X., Gerbig, C., Kolle, O., Kubler, K., Lavric, J., Mikhailov, E., Panov, A., Park, S., Rodenbeck, C., and Skorochod A.: The Zotino Tall Tower Observatory (ZOTTO): Quantifying Large Scale Biogeochemical Changes in Central Siberia, Nova Act. LC., 117, 51-64, 2014. 
Heintzenberg, J., Birmili, W., Otto, R., Andreae, M. O., Mayer, J.C., Chi, X., and Panov, A.: Aerosol particle number size distributions and particulate light absorption at the ZOTTO tall tower (Siberia), 2006-2009, Atmos. Chem. Phys., 11, 87038719, doi:10.5194/acp-11-8703-2011, 2011.

Hickler, T., Vohland, K., Feehan, J., Miller, P. A., Smith, B., Costa, L., Giesecke, T., Fronzek, S., Carter, T. R., Cramer, W., Kühn, I., and Sykes, M. T.: Projecting the future distribution of European potential natural vegetation zones with a generalized, tree species-based dynamic vegetation model, Global Ecol. Biogeogr., 21, 50-63, 2012.

Hirsikko, A., Nieminen, T., Gagné, S., Lehtipalo, K., Manninen, H. E., Ehn, M., Hõrrak, U., Kerminen, V.-M., Laakso, L., McMurry, P. H., Mirme, A., Mirme, S., Petäjä, T., Tammet, H., Vakkari, V., Vana, M., and Kulmala, M.: Atmospheric ions and nucleation: a review of observations, Atmos. Chem. Phys., 11, 767798, doi:10.5194/acp-11-767-2011, 2011.

Hollstein, A. and Fischer, J.: Retrieving aerosol height from the oxygen A band: a fast forward operator and sensitivity study concerning spectral resolution, instrumental noise, and surface inhomogeneity, Atmos. Meas. Tech., 7, 1429-1441, doi:10.5194/amt7-1429-2014, 2014.

Holtslag, A. A. M., Svensson, G., Baas, P., Basu, S., Beare, B., Beljaars, A. C. M., Bosveld, F. C., Cuxart, J., Lindvall, J., Steeneveld, G. J., Tjernström, M., and Van De Wiel, B. J. H: Stable Atmospheric Boundary Layers and Diurnal Cycles: Challenges for Weather and Climate Models, B. Am. Meteorol. Soc., 94, 1691-1706, doi:10.1175/BAMS-D-11-00187.1, 2013.

Hoose, C. and Möhler, O.: Heterogeneous ice nucleation on atmospheric aerosols: a review of results from laboratory experiments, Atmos. Chem. Phys., 12, 9817-9854, doi:10.5194/acp-12-98172012, 2012.

Huffman, G. J., Adler, R. F., Bolvin, D. T., Gu, G. J., Nelkin, E. J., Bowman, K. P., Hong, Y., Stocker, E. F., and Wolff, D. B.: The TRMM multisatellite precipitation analysis (TMPA): Quasiglobal, multiyear, combined-sensor precipitation estimates at fine scales, J. Hydrometeorol., 8, 38-55, 2007.

Hunter, M., Kozlov, M. V., Itämies, J., Pullainen, E., Bäck, J., Kyrö E.-M., and Niemelä, P.: Current temporal trends in moth abundance are counter to predicted effects of climate change in an assemblage of subarctic forest moths, Glob. Change Biol., 20, 1723-1737, doi:10.1111/gcb.12529, 2014.

Huotari, J., Ojala, A., Peltomaa, E., Nordbo, A., Launiainen, S., Pumpanen, J., Rasilo, T., Hari, P., and Vesala, T.: Long-term direct $\mathrm{CO}_{2}$ flux measurements over a boreal lake: Five years of eddy covariance data, Geophys. Res. Lett., 38, LI8401, doi:10.1029/2011GL048753, 2011.

Huotari, J., Haapanala, S., Pumpanen, J., Vesala, T., and Ojala, A.: Efficient gas exchange between a boreal river and the atmosphere, Geophys. Res. Lett., 40, 5683-5686, 2013.

IPCC: Climate Change: The Physical Science Basis. Working Group I Contribution to the Fifth Assessment Report of the Intergovernmental Panel on Climate Change, edited by: Stocker, T. F., Qin, D., Plattner, G.-K., Tignor, M., Allen, S. K., Boschung, J., Nauels, A., Xia, Y., Bex, V., and Midgley, P. M., Cambridge University Press, Cambridge, UK and New York, NY, US, 2013.

IPCC: Climate Change: Impacts, Adaptation, and Vulnerability. Working Group II Contribution to the Fifth Assessment Report of the Intergovernmental Panel on Climate Change, edited by:
Field, C. B., Barros, V. R., Dokken, D. J., Mach, K. J., Mastrandrea M. D., Cambridge University Press, Cambridge, UK, 2014.

IPCC SRES: Special Report on Emissions Scenarios: A special report of Working Group III of the Intergovernmental Panel on Climate Change, edited by: Nakićenović, N. and Swart, R., Cambridge University Press, Cambridge, UK, 2000.

Isidorov, V. A.: Organic chemistry of the atmosphere, Khimizdat, Moscow, Russia, 2001 (in Russian).

Jaffe, D. A. and Wigder, N. L.: Ozone production from wildfires: a critical review, Atmos. Environ., 51, 1-10, 2012.

Jeong, J.-H., Kug, J.-S., Kim, B.-M., Min, S.-K., Linderholm, H. W., Ho, C.-H., Rayner, D., Chen, D., and Jun, S.-Y.: Greening in the circumpolar high-latitude may amplify warming in the growing season, Clim. Dynam., 38, 1421-143, 2011.

Jolleys, M. D., Coe, H., McFiggans, G., Taylor, J. W., O'Shea, S. J., Le Breton, M., Bauguitte, S. J.-B., Moller, S., Di Carlo, P., Aruffo, E., Palmer, P. I., Lee, J. D., Percival, C. J., and Gallagher, M. W.: Properties and evolution of biomass burning organic aerosol from Canadian boreal forest fires, Atmos. Chem. Phys., 15, 3077-3095, doi:10.5194/acp-15-3077-2015, 2015.

Jones, A. M. and Harrison, R. M.: Temporal trends in sulphate concentrations at European sites and relationships to sulphur dioxide, Atmos. Environ. 45, 873-882, 2011.

Jonsson, M. and Wardle, D. A.: Structural equation modeling reveals plant-community drivers of carbon storage in boreal forest ecosystems, Biol. Lett.-UK, 6, 116-119, 2010.

Joyce, R. J., Janowiak, J. E., Arkin, P. A., and Xie, P. P.: CMORPH A method that produces global precipitation estimates from passive microwave and infrared data at high spatial and temporal resolution, J. Hydrometeorol., 5, 487-503, 2004.

Kaiser, J. W., Heil, A., Andreae, M. O., Benedetti, A., Chubarova, N., Jones, L., Morcrette, J.-J., Razinger, M., Schultz, M. G., Suttie, M., and van der Werf, G. R.: Biomass burning emissions estimated with a global fire assimilation system based on observed fire radiative power, Biogeosciences, 9, 527-554, doi:10.5194/bg-9-527-2012, 2012.

Kalinina, O., Goryachkin, S. V., Karavaeva, N. A., Lyuri, D. I., Najdenko, L., and Giani, L.: Self-restoration of post-agrogenic sandy soils in the southern Taiga of Russia: Soil development, nutrient status, and carbon dynamics, Geoderma, 152, 35-42, 2009.

Kapsch, M.-L., Graversen, R. G., and Tjernström, M.: Springtime atmospheric energy transport and the control of Arctic summer sea-ice extent, Nat. Clim. Change, 3, 744-748, doi:10.1038/nclimate1884, 2013.

Karhu, K., Auffret, M. D., Dungait, J. A. J., Hopkins, D. W., Prosser, J. I., Singh, B. K., Subke, J.-A., Wookey, P. A., Ågren, G. I., Sebastia, M.-T., Gouriveau, F., Bergkvist, G., Meir, P., Nottingham, A. T., Salina, N., and Hartley, I. P.: Temperature sensitivity of soil respiration rates enhanced by microbial community response, Nature, 513, 81-84, doi:10.1038/nature13604, 2014.

Karpoff, B. S. and Roscoe, W. E.: Report on Placer Gold Properties in the Tuul Valley, Zaamar Goldfield, Mongolia, Roscoe Postle Associates INC, Toronto, Ontario, 1-66, 2005.

Karthe, D., Kasimov, N., Chalov, S., Shinkareva, G., Malsy, M., Menzel, L., Theuring, P., Hartwig, M., Schweitzer, C., Hofmann, J., Priess, J., and Lychagin, M.: Integrating Multi-Scale Data for the Assessment of Water Availability and Quality in the KharaaOrkhon-Selenga River System, Geography, Environment, Sustainability, 3, 65-86, 2014. 
Kasischke, E. S.: Boreal ecosystems in the global carbon cycle, in: Fire, Climate Change and Carbon Cycling in the Boreal Forest, edited by: Kasischke, E. S. and Stocks, B. J., Ecological Studies, Springer Verlag, New York, USA, 138, 19-30, 2000.

Kay, J. E., L’Ecuyer, T., Gettelman, A., Stephens, G., and O’Dell, C.: The contribution of cloud and radiation anomalies to the 2007 Arctic sea ice extent minimum, Geophys. Res. Lett., 35, L08503, doi:10.1029/2008GL033451, 2008.

Khazheeva, Z. I., Tulokhonov, A. K., Yao, R., and Hu, W. P.: Seasonal and spatial distribution of heavy metals in the Selenga River Delta, J. Geogr. Sci., 18, 319-327, 2008.

Khvorostyanov, D. V., Ciais, P., Krinner, G., and Ziv, S. A.: Vulnerability of East Siberia's frozen carbon stores to future warming, Geophys. Res. Lett., 35, L10703, doi:10.1029/2008GL033639, 2008.

Kim, B.-M., Son, S.-W., Min, S.-K., Jeong, J.-H., Kim, S.-J., Zhang, X., Shim, T., and Yoon, J.-H.: Weakening of the stratospheric polar vortex by Arctic sea-ice loss, Nat. Commun., 5, 4646, doi:10.1038/ncomms5646, 2014.

Koch, D. and Del Genio, A. D.: Black carbon semi-direct effects on cloud cover: review and synthesis, Atmos. Chem. Phys., 10, 7685-7696, doi:10.5194/acp-10-7685-2010, 2010.

Kolmonen, P., Sogacheva, L., Virtanen, T. H., de Leeuw, G., and Kulmala, M.: The ADV/ASV AATSR aerosol retrieval algorithm: current status and presentation of a fullmission AOD data set, Int. J. Digit. Earth, 9, 545-561, doi:10.1080/17538947.2015.1111450, 2015.

Kolstad, E. W., Bracegirdle, T. J., and Seierstad, I. A.: Marine cold air outbreaks in the North Atlantic: temporal distributionand associations with large-scale atmospheric circulation, Clim. Dynam., 33, 187-197, 2009.

Konovalov, I. B., Berezin, E. V., Ciais, P., Broquet, G., Beekmann, M., Hadji-Lazaro, J., Clerbaux, C., Andreae, M. O., Kaiser, J. W., and Schulze, E.-D.: Constraining $\mathrm{CO}_{2}$ emissions from open biomass burning by satellite observations of co-emitted species: a method and its application to wildfires in Siberia, Atmos. Chem. Phys., 14, 10383-10410, doi:10.5194/acp-14-10383-2014, 2014.

Konovalov, I. B., Beekmann, M., Berezin, E. V., Petetin, H., Mielonen, T., Kuznetsova, I. N., and Andreae, M. O.: The role of semi-volatile organic compounds in the mesoscale evolution of biomass burning aerosol: a modeling case study of the 2010 mega-fire event in Russia, Atmos. Chem. Phys., 15, 1326913297, doi:10.5194/acp-15-13269-2015, 2015.

Konstantinov, P. I., Varentsov, M. I., and Malinina, E. P.: Modeling of thermal comfort conditions inside the urban boundary layer during Moscow's 2010 summer heat wave (case-study), Urban Climate, 10, 563-572, 2014.

Konstantinov, P. I., Grishchenko, M. Y., and Varentsov, M. I.: Mapping of Arctic Cities Urban Heat Island Based on the Composition of Field Meteorological Measurements and Satellite Derived Imagery (Example of Apatity, Kola Peninsula), Issledovanie Zemli iz kosmosa, Izv. Atmos. Ocean. Phy.+, 51, doi:10.7868/S0205961415030069 (in press), 2015.

Korhonen, J. F. J., Pihlatie, M., Pumpanen, J., Aaltonen, H., Hari, P., Levula, J., Kieloaho, A.-J., Nikinmaa, E., Vesala, T., and Ilvesniemi, H.: Nitrogen balance of a boreal Scots pine forest, Biogeosciences, 10, 1083-1095, doi:10.5194/bg-10-1083-2013, 2013.

Korontzi, S., McCarty, J., Loboda, T., Kumar, S., and Justice, C.: Global distribution of agricultural fires in croplands from 3 years of Moderate Resolution Imaging Spectroradiometer (MODIS) data, Global Biogeochem. Cy., 20, GB2021, doi:10.1029/2005GB002529, 2006.

Kortelainen, P., Rantakari, M., Huttunen, J. T., Mattsson, T., Alm, J., Juutinen, S., Larmola, T., Silvola, J., and Marikainen, P.: Sediment respiration and lake trophic state are important predictors of large $\mathrm{CO}_{2}$ evasion from small boreal lakes, Glob. Change Biol., 12, 1554-1567, 2006.

Korytnyi, L. M.: Urgent tasks of geographical resources management, in: Resource Economics, Environmental Economics and Climate Change, edited by: Vaganov, E. A. et al., Materials of the International Conference, 1-7 July 2009, Siberian Federal University, Krasnoyarsk, Russia, 359-366, 2009.

Kosobokova, K. N.: Zooplankton of ther Arctic Basin, GEOS, Moscow, Russia, 2012.

Köster, K., Berninger, F., Lindén, A., and Pumpanen, J.: Recovery in fungal biomass is related to decrease in soil organic matter turnover time in a boreal fire chronosequence, Geoderma, 235236, 74-82, 2014.

Kotilainen, J., Tysiachniouk, M., Kuliasova, A., Kuliasov, I., and Pchelkina, S.: The potential for ecological modernisation in Russia: scenarios from the forest industry, Environ. Polit., 17, 58-77, 2008.

Kozlova, E. A., Manning, A. C., Kisilyakhov, Y., Seifert, T., and Heimann, M.: Seasonal, synoptic, and diurnal-scale variability of biogeochemical trace gases and $\mathrm{O}_{2}$ from a 300-m tall tower in central Siberia, Global Biogeochem. Cy., 22, GB4020, doi:10.1029/2008GB003209, 2008.

Kug, J.-S., Jeong, J.-H., Jang, Y.-S., Kim, B.-M., Kim, Folland, C. K., Min, S.-K., and Son, S.-W.: Two distinct influences of Arctic warming on cold winters over North America and East Asia, Nat. Geosci.,8, 759-762, doi:10.1038/ngeo2517, 2015.

Kukkola, E., Huttunen, S., Bäck, J., and Rautio, P.: Scots pine needle injuries at subarctic industrial sites, Trees, 11, 378-387, 1997.

Kulmala, L., Aaltonen, H., Berninger, F., Kieloaho, A.-J., Levula, J., Bäck, J., Hari, P., Kolari, P., Korhonen, J. F. J., Kulmala, M., Nikinmaa, E., Pihlatie, M., Vesala, T., and Pumpanen, J.: Changes in biogeochemistry and carbon fluxes after the clearcutting and partial burning of slash, Agr. Forest Meteorol., 188, 33-44, 2014.

Kulmala, M.: China's choking cocktail, Nature, 526, 497-499, doi:10.1038/526497a, 2015.

Kulmala, M. and Petäjä, T.: Soil nitrites influence atmospheric chemistry, Science, 333, 1586-1587, 2011.

Kulmala, M., Dal Maso, M., Mäkelä, J. M., Pirjola, L., Väkevä, M., Aalto, P., Miikkulainen, P., Hämeri, K., and O'Dowd, C. D.: On the formation, growth and composition of nucleation mode particles, Tellus B, 53, 479-490, 2001.

Kulmala, M., Suni, T., Lehtinen, K. E. J., Dal Maso, M., Boy, M., Reissell, A., Rannik, Ü., Aalto, P., Keronen, P., Hakola, H., Bäck, J., Hoffmann, T., Vesala, T., and Hari, P.: A new feedback mechanism linking forests, aerosols, and climate, Atmos. Chem. Phys., 4, 557-562, doi:10.5194/acp-4-557-2004, 2004a.

Kulmala, M., Laakso, L., Lehtinen, K. E. J., Riipinen, I., Dal Maso, M., Anttila, T., Kerminen, V.-M., Hõrrak, U., Vana, M., and Tammet, H.: Initial steps of aerosol growth, Atmos. Chem. Phys., 4, 2553-2560, doi:10.5194/acp-4-2553-2004, 2004b.

Kulmala, M., Asmi, A., Lappalainen, H. K., Carslaw, K. S., Pöschl, U., Baltensperger, U., Hov, Ø., Brenquier, J.-L., Pandis, S. 
N., Facchini, M. C., Hansson, H.-C., Wiedensohler, A., and O'Dowd, C. D.: Introduction: European Integrated Project on Aerosol Cloud Climate and Air Quality interactions (EUCAARI) - integrating aerosol research from nano to global scales, Atmos. Chem. Phys., 9, 2825-2841, doi:10.5194/acp-9-2825-2009, 2009.

Kulmala, M., Alekseychik, P., Paramonov, M., Laurila, T., Asmi, E., Arneth, A., Zilitinkevich, S., and Kerminen, V.-M.: On measurements of aerosol particles and greenhouse gases in Siberia and future research needs, Boreal Environ. Res., 16, 337-362, 2011a.

Kulmala, M., Asmi, A., Lappalainen, H. K., Baltensperger, U., Brenguier, J.-L., Facchini, M. C., Hansson, H.-C., Hov, Ø., O'Dowd, C. D., Pöschl, U., Wiedensohler, A., Boers, R., Boucher, O., de Leeuw, G., Denier van der Gon, H. A. C., Feichter, J., Krejci, R., Laj, P., Lihavainen, H., Lohmann, U., McFiggans, G., Mentel, T., Pilinis, C., Riipinen, I., Schulz, M., Stohl, A., Swietlicki, E., Vignati, E., Alves, C., Amann, M., Ammann, M., Arabas, S., Artaxo, P., Baars, H., Beddows, D. C. S., Bergström, R., Beukes, J. P., Bilde, M., Burkhart, J. F., Canonaco, F., Clegg, S. L., Coe, H., Crumeyrolle, S., D’Anna, B., Decesari, S., Gilardoni, S., Fischer, M., Fjaeraa, A. M., Fountoukis, C., George, C., Gomes, L., Halloran, P., Hamburger, T., Harrison, R. M., Herrmann, H., Hoffmann, T., Hoose, C., Hu, M., Hyvärinen, A., Hõrrak, U., Inuma, Y., Iversen, T., Josipovic, M., Kanakidou, M., Kiendler-Scharr, A., Kirkevåg, A., Kiss, G., Klimont, Z., Kolmonen, P., Komppula, M., Kristjánsson, J.-E., Laakso, L., Laaksonen, A., Labonnote, L., Lanz, V. A., Lehtinen, K. E. J., Rizzo, L. V., Makkonen, R., Manninen, H. E., McMeeking, G., Merikanto, J., Minikin, A., Mirme, S., Morgan, W. T., Nemitz, E., O’Donnell, D., Panwar, T. S., Pawlowska, H., Petzold, A., Pienaar, J. J., Pio, C., Plass-Duelmer, C., Prévôt, A. S. H., Pryor, S., Reddington, C. L., Roberts, G., Rosenfeld, D., Schwarz, J., Seland, Ø., Sellegri, K., Shen, X. J., Shiraiwa, M., Siebert, H., Sierau, B., Simpson, D., Sun, J. Y., Topping, D., Tunved, P., Vaattovaara, P., Vakkari, V., Veefkind, J. P., Visschedijk, A., Vuollekoski, H., Vuolo, R., Wehner, B., Wildt, J., Woodward, S., Worsnop, D. R., van Zadelhoff, G.-J., Zardini, A. A., Zhang, K., van Zyl, P. G., Kerminen, V.-M., S Carslaw, K., and Pandis, S. N.: General overview: European Integrated project on Aerosol Cloud Climate and Air Quality interactions (EUCAARI) - integrating aerosol research from nano to global scales, Atmos. Chem. Phys., 11, 13061-13143, doi:10.5194/acp11-13061-2011, 2011b.

Kulmala, M., Nieminen, T., Chellapermal, R., Makkonen, R., Bäck, J., and Kerminen, V.-M.: Climate feedbacks linking the increasing atmospheric $\mathrm{CO}_{2}$ concentration, BVOC emissions, aerosols and clouds in forest ecosystems, in: Biology, Controls and Models of Tree Volatile Organic Compound Emissions, edited by: Niinemets, Ü and Monson, R. K., Springer Springer Sceince + Business Media, Dortrecht, the Netherlands, 489-508, 2013.

Kulmala, M., Nieminen, T., Nikandrova, A., Lehtipalo, K., Manninen, H. E., Kajos, M. K., Kolari, P., Lauri, A., Petäjä, T., Krejci, R., Hansson, H.-C., Swietlicki, E., Lindroth, A., Christensen, T. R., Arneth, A., Hari, P., Bäck, J., Vesala, T., and Kerminen, V.M.: $\mathrm{CO}_{2}$-induced terrestrial climate feedback mechanism: From carbon sink to aerosol source and back, Suppl. B, Boreal Environ. Res., 19, 12-131, 2014.
Kulmala, M., Lappalainen, H. K., Petäjä, T., Kurten, T., Kerminen, V.-M., Viisanen, Y., Hari, P., Sorvari, S., Bäck, J., Bondur, V., Kasimov, N., Kotlyakov, V., Matvienko, G., Baklanov, A., Guo, H. D., Ding, A., Hansson, H.-C., and Zilitinkevich, S.: Introduction: The Pan-Eurasian Experiment (PEEX) multidisciplinary, multiscale and multicomponent research and capacity-building initiative, Atmos. Chem. Phys., 15, 1308513096, doi:10.5194/acp-15-13085-2015, 2015.

Kulmala, M., Lappalainen, H. K., Petäjä, T., Kerminen, V. M., Viisanen, Y., Matvienko, G., Melnikov, V., Baklanov, A., Bondur, V., Kasimov, N., and Zilitinkevich, Z.: Pan-Eurasian Experiment (PEEX) Program: Grant Challenges in the Arctic-boreal context, J. Geography, Environment and Sustainability, 2, 5-18, 2016.

Kummerow, C., Hong, Y., Oleson, W. S., Yang, S., Adler, R. F., Mccollum, J., Ferraro, R., Petty, G., Shin, D. B., and Wilheit, T. T.: The evolution of the Goddard profiling algorithm (GPROF) for rainfall estimation from passive microwave sensors, J. Appl. Meteorol., 40, 1801-1820, 2001.

Kurz, W. A. and Apps, M. J.: An analysis of future carbon budgets of Canadian boreal forests, Water Air Soil Poll., 82, 321-331, 1995.

Kurz, W. A., Dymond, C. C., Stinson, G., Rampley, G. J., Neilson, E. T., Carroll, A. L., Ebata, T., and Safranyik, L.: Mountain pine beetle and forest carbon feedback to climate change, Nature, 452, 987-990, 2008a.

Kurz, W. A., Stinson, G., Rampley, G. J., Dymond, C. C., and Neilson, E. T.: Risk of natural disturbances makes future contribution of Canada's forests to the global carbon cycle highly uncertain, P. Natl. Acad. Sci., 105, 1551-1555, doi10.1073pnas.0708133105, 2008b.

Kuzyakov, Y.: Priming effects: Interactions between living and dead organic matter, Soil Biol. Biochem., 42, 1363-1371, 2010.

Kvaeven, B., Ulstein, M. J., and Skjelkvåle, B. L.: ICP Waters - An international programme for surface water monitoring, Water Air Soil Poll., 130, 775-780, 2001.

Kwok, R. and Rothrock, D. A.: Decline in Arctic sea ice thickness from submarine and ICESat records: 1958-2008, Geophys. Res. Lett., 36, L15501, doi:10.1029/2009GL039035, 2009.

Laaksonen, A. and Malila, J.: An adsorption theory of heterogeneous nucleation of water vapour on nanoparticles, Atmos. Chem. Phys., 16, 135-143, doi:10.5194/acp-16-135-2016, 2016.

Laaksonen, A. A.: Unifying model for adsorption and nucleation of vapors on solid surfaces, J. Phys. Chem. A, 119, 3736-3745, 2015.

Laothawornkitkul, J., Taylor, J. E., Paul, N. D., and Hewitt, C. N.: Biogenic volatile organic compounds in the Earth system, New Phytol., 183, 27-51, 2009.

Lappalainen, H. K., Petäjä, T., Kujansuu, J., Kerminen, V.-M., Shvidenko, A., Bäck, J., Vesala, T., Vihma, T., de Leeuw, G., Lauri, A., Ruuskanen, T., Flint, M., Zaitseva, N., Arshinov, M., Spracklen, D., Arnold, S., Juhola, S., Lihavainen, H., Viisanen, Y., Chubarova, N., Filatov, N., Skorokhod, A., Elansky, N., Dyukarev, E., Hari, P., Kotlyakov, V., Kasimov, N., Bondur, V., Matvienko, G., Baklanov, A., Guo, H., Zilitinkevich, S., and Kulmala, M.: Pan-Eurasian Experiment (PEEX) - a research initiative meeting the grand challenges of the changing environment of the northern Pan-Eurasian arctic-boreal areas, J. Geography Environment Sustainability, 2, 13-48, 2014. 
Lenhart, K., Weber, B., Elbert, W., Steinkamp, J., Clough, T., Crutzen, P., Pöschl, U., and Keppler, F.: Nitrous oxide and methane emissions from cryptogamic covers, Glob. Change Biol., 21, 3889-3900, doi:10.1111/gcb.12995, 2015.

Liang, Q., Rodriguez, J. M., Douglass, A. R., Crawford, J. H., Olson, J. R., Apel, E., Bian, H., Blake, D. R., Brune, W., Chin, M., Colarco, P. R., da Silva, A., Diskin, G. S., Duncan, B. N., Huey, L. G., Knapp, D. J., Montzka, D. D., Nielsen, J. E., Pawson, S., Riemer, D. D., Weinheimer, A. J., and Wisthaler, A.: Reactive nitrogen, ozone and ozone production in the Arctic troposphere and the impact of stratosphere-troposphere exchange, Atmos. Chem. Phys., 11, 13181-13199, doi:10.5194/acp-11-13181-2011, 2011.

Lihavainen, H., Kerminen, V.-M., Tunved, P., Aaltonen, V., Arola, A., Hatakka, J., Hyvärinen, A., and Viisanen, Y.: Observational signature of the direct radiative effect by natural boreal forest aerosols and its relation to the corresponding first indirect effect, J. Geophys. Res., 114, D20206, doi:10.1029/2009JD012078, 2009.

Lihavainen, H., Asmi, E., Aaltonen, V., Makkonen U., and Kerminen, V.-M.: Direct radiative feedback due to biogenic secondary organic aerosol estimated from boreal forest site observations, Environ. Res. Lett., 10, 104005, doi:10.1088/17489326/10/10/104005, 2015.

Litvinenko, T. V.: Socioecological Consequences of Transformation of Natural Resources Utilization in Russia's Eastern Part in PostSoviet Period, Regional Research of Russia, 2, 284-295, 2012.

Litvinenko, T. V.: Post-Soviet Transformation of Natural Resources Utilization and its Impact on Population Dynamics in Chukotka Autonomous Okrug, Izvestiya of Russian Academy of Sciences, Geography, 2, 30-42, 2013 (in Russian).

Liu, Y. Y., Parinussa, R. M., Dorigo, W. A., De Jeu, R. A. M., Wagner, W., van Dijk, A. I. J. M., McCabe, M. F., and Evans, J. P.: Developing an improved soil moisture dataset by blending passive and active microwave satellite-based retrievals, Hydrol. Earth Syst. Sci., 15, 425-436, doi:10.5194/hess-15-425-2011, 2011.

Lloyd, A. H. and Bunn, A. G.: Responses of the circumpolar boreal forest to 20th century climate variability, Environ. Res. Lett., 2, 045013, doi:10.1088/1748-9326/2/4/045013, 2007.

Lu, Z., Zhang, Q., and Streets, D. G.: Sulfur dioxide and primary carbonaceous aerosol emissions in China and India, 1996-2010, Atmos. Chem. Phys., 11, 9839-9864, doi:10.5194/acp-11-98392011, 2011.

Lyuri, D. I., Goryachkin, S. V., Karavaeva, N. A., Denisenko, E. A., and Nefedova, T. G.: Dynamics of agricultural lands in Russia in 20th century and post-agrogenic progradation of vegetation and soils, GEOS, Moscow, Russia, 2010 (in Russian).

Magnani, F., Mencuccini, M., Borghetti, M., Berbigier, P., Berninger, F., Delzon, S., Grelle, A., Hari, P., Jarvis, P. G., Kolari, P., Kowalski, A. S., Lankreijer, H., Law, B. E., Lindroth, A., Loustau, D., Manca, G., Moncrieff, J. B., Rayment, M., Tedeschi, V., Valentini, R., and Grace, J.: The human footprint in the carbon cycle of temperate and boreal forests, Nature, 447, 848-850, 2007.

Mäkelä, J. M., Aalto, P., Pohja, T., Nissinen, A., Palmroth, S., Markkanen, T., and Kulmala, M.: Observations of ultrafine aerosol particle formation and growth in boreal forest, Geophys. Res. Lett., 24, 1219-1222, 1997.
Makshtas, A., Nedashkovsky, A. P., and Uttal, T.: The role of the Arctic sea ice in carbon dioxide exchange, AMS Conf. on Polar Meteor. Ocean, 3 May 2011, Boston, USA, 2011.

Maksimovich, E. and Vihma, T.: The effect of surface heat fluxes on interannual variability in the spring onset of sMaoow melt in the central Arctic Ocean, J. Geophys. Res., 117, C07012, doi:10.1029/2011JC007220, 2012.

Malevsky-Malevich, S. P., Molkentin, E. K., Nadyozhina, E. D., and Shklyarevich, O. B.: An assessment of potential change in wilfire activity in the Russian boreal forest zone induced by climate warming during the twenty-first century, Climatic Change, 86, 463-474, 2008.

Malin, G., Turner, S., Liss, P., Holligan, P., and Harbour, D.: Dimethylsulphide and dimethylsulphoniopropionate int Northeast Atlantic during the summer coccolithothophore bloom, Deep-Sea Res. Pt. I, 40, 1487-1508, 1993.

Maljanen, M., Sigurdsson, B. D., Guðmundsson, J., Óskarsson, H., Huttunen, J. T., and Martikainen, P. J.: Greenhouse gas balances of managed peatlands in the Nordic countries - present knowledge and gaps, Biogeosciences, 7, 2711-2738, doi:10.5194/bg7-2711-2010, 2010.

Malkhazova, S. M., Mironova, V. V., Kotova, T. V., Shartova, N. V., and Orlov, D. S.: Natural Focal Diseases in Russia: Monitoring and Mapping, Geography, Environment, Sustainability, 4, 4-12, 2013.

Mann, P. J., Davydova, A., Zimov, N., Spencer, R., Davydov, S., Bulygina, E., Zimov, S., and Holmes, R.: Controls on the composition and lability of dissolved organic matter in Siberia's Kolyma River basin, J. Geophys. Res. 117, G01028, 2012.

Mareev, E.: Global electric circuit research: achievements and prospects, Uspekhi Fizicheskikh Nauk and P. N. Lebedev Physics Institute of the Russian Academy of Sciences, Physics-Uspekhi, 53, 504-511, 2010.

Mauldin, R. L., Berndt, T., Sipilä, M., Paasonen, P., Petäjä, T., Kim, S., Kurtén, T., Stratmann, F., Kerminen, V.-M., and Kulmala, M.: A new atmospherically relevant oxidant of sulphur dioxide, Nature, 488, 193-196, 2012.

McComiskey, A. and Feingold, G.: The scale problem in quantifying aerosol indirect effects, Atmos. Chem. Phys., 12, 1031-1049, doi:10.5194/acp-12-1031-2012, 2012.

Meinander, O., Kazadzis, S., Arola, A., Riihelä, A., Räisänen, P., Kivi, R., Kontu, A., Kouznetsov, R., Sofiev, M., Svensson, J., Suokanerva, H., Aaltonen, V., Manninen, T., Roujean, J.-L., and Hautecoeur, O.: Spectral albedo of seasonal snow during intensive melt period at Sodankylä, beyond the Arctic Circle, Atmos. Chem. Phys., 13, 3793-3810, doi:10.5194/acp-13-37932013, 2013.

Menzel, A., Sparks, T. H., Estrella, N., Koch, E., Aasa, A., Aha, R., Alm-Kubler, K., Bissolli, P., Braslavska, O., Briede, A., Chmielewski, F. M., Crepinsek, Z., Curnel, Y., Dahl, A., Defila, C., Donnelly, A., Filella, Y., Jatcza, K., Måge, F., Mestre, A., Nordli, O., Penuuelas, J., Pirinen, P., Remisova, V., Scheifinger, H., Striz, M., Susni, A., Van Vliet, A. J. H., Wielgolaski, F.-E., Zach, S., and Zust, A.: European phenological response to climate change matches the warming pattern, Glob. Change Biol., 12, 1969-1976, 2006.

Mijling, B., van der A, R. J., and Zhang, Q.: Regional nitrogen oxides emission trends in East Asia observed from space, 
Atmos. Chem. Phys., 13, 12003-12012, doi:10.5194/acp-1312003-2013, 2013.

Mikhailov, E. F., Mironov, G. N., Pöhlker, C., Chi, X., Krüger, M. L., Shiraiwa, M., Förster, J.-D., Pöschl, U., Vlasenko, S. S., Ryshkevich, T. I., Weigand, M., Kilcoyne, A. L. D., and Andreae, M. O.: Chemical composition, microstructure, and hygroscopic properties of aerosol particles at the Zotino Tall Tower Observatory (ZOTTO), Siberia, during a summer campaign, Atmos. Chem. Phys., 15, 8847-8869, doi:10.5194/acp-15-88472015, 2015a.

Mikhailov, E. F., Mironova, S. Y., Makarova, M. V., Vlasenko, S. S., Ryshkevich, T. I., Panov, A. V., and Andreae, M. O.: Studying seasonal variations in carbonaceous aerosol particles in the atmosphere over Central Siberia, Izv. Atmos. Ocean. Phy.+, 51, 423-430, doi:10.1134/S000143381504009X, 2015b.

Moiseenko, T. I., Kydrjavzeva, L. P., and Sandimirov, S. S.: Principles and methods of water quality studies for airborne polluted water bodies: case study of Kola Subarctic, Water Res., 27, 8186, 2001.

Monks, S. A., Arnold, S. R., Emmons, L. K., Law, K. S., Turquety, S., Duncan, B. N., Flemming, J., Huijnen, V., Tilmes, S., Langner, J., Mao, J., Long, Y., Thomas, J. L., Steenrod, S. D., Raut, J. C., Wilson, C., Chipperfield, M. P., Diskin, G. S., Weinheimer, A., Schlager, H., and Ancellet, G.: Multi-model study of chemical and physical controls on transport of anthropogenic and biomass burning pollution to the Arctic, Atmos. Chem. Phys., 15, 3575-3603, doi:10.5194/acp-15-3575-2015, 2015.

Moore, S. K., Trainer, V. L., Mantua, N. J., Parker, M. S., Laws, E. A., Bacher, L. C., and Fleming, L. E.: Impacts of climate variability and future climate change on harmful algal blooms and human health, Environ. Health, Supplement S4, doi:10.1186/1476069X-7-S2-S4, 2008.

Mori, M., Watanabe, M., Shiogama, H., Inoue, J., and Kimoto, M.: Robust Arctic sea-ice influence on the frequent Eurasian cold winters in past decades, Nat. Geosci., 7, 869-873, doi:10.1038/NGEO2277, 2014.

Mu, Q., Heinsch, F. A., Zhao, M., and Running, S. W.: Development of a global evapotranspiration algorithm based on MODIS and global meteorology data, Remote Sens. Environ., 111, 519-536, 2007.

Mukhrtova, L., Schepaschenko, D., Shvidenko, A., McCallum, I., and Kraxner, F.: Soil contribution to carbon budget of Russian forests, Agr. Forest Meteorol., 200, 97-118, 2015.

Müller, B., Lotter, A. F., and Sturm, A. A.: Influence of catchment quality and altitude on the water and sediment composition of 68 small lakes in Central Europe, Aquat. Sci., Research Across Boundaries, 60, 316-337, 1998.

Myneni, R. B., Keeling, C. D., Tucker, C. J., Asrar, G., and Nemani, R. R.: Increased plant growth in the northern high latitudes from 1981 to 1991 , Nature, 386, 698-702, 1997.

Naeger, A. R., Gupta, P., Zavodsky, B. T., and McGrath, K. M.: Monitoring and tracking the trans-Pacific transport of aerosols using multi-satellite aerosol optical depth composites, Atmos. Meas. Tech., 9, 2463-2482, doi:10.5194/amt-9-24632016, 2016.

Nédélec, P., Thouret, V., Brioude, J., Sauvage, B., Cammas, J. P., and Stohl, A.: Extreme CO concentrations in the upper troposphere over northeast Asia in June 2003 from the in situ MOZAIC aircraft data, Geophys. Res. Lett., 32, L14807, doi:10.1029/2005GL023141, 2005.

Nelson, D. L., Garay, M. J., Kahn, R. A., and Dunst, B. A.: Stereoscopic Height and Wind Retrievals for Aerosol Plumes with the MISR INteractive eXplorer (MINX), Remote Sens., 5, 45934628, doi:10.3390/rs5094593, 2013.

Nie, W., Ding, A., Wang, T., Kerminen, V.-M., George, C., Xue, L., Wang, W., Zhang, Q., Petäjä, T., Qi, X., Gao, X., Wang, X., Yang, X., Fu, C., and Kulmala, M.: Polluted dust promotes new particle formation and growth, Sci. Rep., 4, 6634, doi:10.1038/srep06634, 2014.

Nöjd, P. and Kauppi, P.: Growth of Scots pine in a changing environment, in: Kola Peninsula pollutants and forest ecosystems in Lapland, edited by: Tikkanen, E. and Niemela, I., Final report of the Lapland Forest Damage Project. Finland's Ministry of Agriculture and Forestry, The Finnish Forest Research Institute, Gummerus Kirjapaino Oy, Jyväskylä, 61-64, 1995.

O'Dowd, C. D. and de Leeuw, G.: Marine Aerosol Production: a review of the current knowledge, Philos. T. R. Soc. A, 365, 1753 1774, doi:10.1098/rsta.2007.2043, 2007.

O’Dowd, C. D., Facchini, M.C., Cavalli, F., Ceburnis, D., Mircea, M., Decesari, S., Fuzzi, S., Yoon, Y. J., and Putaud, J.-P.: Biogenically driven organic contribution to marine aerosol, Nature, 431, 676-680, doi:10.1038/nature02959, 2004.

Osawa, A., Zyryanova, O. A., Matsuura, Y., Kajamoto, T., and Wein, R. W. (Eds.): Permafrost Ecosystems, Siberian Larch Forests, Ecological Studies, 209, Springer Science + Business Media B. V., Springer Netherlands, 502 pp., doi:10.1007/978-14020-9693-8, 2010.

Outten, S., Davy, R., and Esau, I.: Eurasian winter cooling: Intercomparison of Reanalyses and CMIP5 data sets, Atmospheric and Oceanic Science Letters, 6, 324-331, doi:10.3878/j.issn.1674-2834.12.0112, 2013.

Overland, J., Francis, J., Hall, R., Hanna, E., Kim, S.-J., and Vihma, T.: The Melting Arctic and Mid-latitude Weather Patterns: Are They Connected?, J. Climate, 28, 7917-7932, doi:10.1175/JCLID-14-00822.1, 2015.

Paasonen, P., Asmi, A., Petäjä, T., Kajos, M. K., Äijälä, M., Junninen, H., Holst, T., Abbatt, J. P. D., Arneth, A., Birmili, W., Denier van der Gon, H., Hamed, A., Hoffer, A., Laakso, L., Laaksonen, A., Leaitch, W. R., Plass-Dulmer, C., Pryor, S. C., Räisänen, P., Swietlicki, E., Wiedensohler, A., Worsnop, D. R., Kerminen, V.M., and Kulmala, M.: Evidence for negative climate feedback: warming increases aerosol number concentrations, Nat. Geosci., 6, 438-442, doi:10.1038/ngeo1800, 2013.

Paatero, J., Dauvalter, V., Derome, J., Lehto, J., Pasanen, J., Vesala, T., Miettinen, J., Makkonen, U., Kyrö, E.-M., Jernström, J., Isaeva, L., and Derome, K.: Effects of Kola air pollution on the environment in the western part of the Kola Peninsula and Finnish Lapland - Final report, Finnish Meteorological Institute Rep., 6, 1-26, 2008.

Paerl, H. W. and Huisman, J.: Climate change: a catalyst for global expansion of harmful cyanobacterial blooms, Environ. Microbiol. Rep., 1, 27-37, 2009.

Paris, J.-D., Ciais, P., Nedelec, P., Ramonet, M., Golytsin, G., Granberg, I., Athier, G., Boumard, F., Cousin, J.-M., Cayez, G., and Stohl, A.: The YAK-AEROSIB transcontinental aircraft campaigns: new insights on the transport of $\mathrm{CO}_{2}, \mathrm{CO}$ and $\mathrm{O}_{3}$ across Siberia, Tellus B, 60, 551-568, 2008. 
Paris, J.-D., Ciais, P., Nedelec, P., Stohl, A., Belan, B. D., Arshinov, M. Y., Carouge, C., Golitsyn, G. S., and Granberg, I. G.: New Insights on the Chemical Composition of the Siberian Air Shed from the YAK-AEROSIB Aircraft Campaigns, B. Am. Meteorol. Soc., 91, 625-641, 2010a.

Paris, J.-D., Stohl, A., Ciais, P., Nédélec, P., Belan, B. D., Arshinov, M. Yu., and Ramonet, M.: Source-receptor relationships for airborne measurements of $\mathrm{CO}_{2}, \mathrm{CO}$ and $\mathrm{O}_{3}$ above Siberia: a cluster-based approach, Atmos. Chem. Phys., 10, 1671-1687, doi:10.5194/acp-10-1671-2010, 2010b.

Parmentier, F. J. W., van der Molen, M. K., van Huissteden, J., Karsanaev, S. A., Kononov, S. V., Suzdalov, D. A., Maximov, T. C., and Dolman, A. J.: Longer growing seasons do not increase net carbon uptake in the northeastern Siberian tundra, J. Geophys. Res., 116, G04013, doi:10.1029/2011JG001653, 2011.

Parmentier, F.-J. W., Christensen, T. R., Sørensen, L. L., Rysgaard, S., McGuire, A. D., Miller P. A., and Walker, D. A.: The impact of lower sea-ice extent on arctic greenhouse-gas exchange, Nat. Clim. Change, 3, 195-202, 2013.

Parrington, M., Palmer, P. I., Lewis, A. C., Lee, J. D., Rickard, A. R., Di Carlo, P., Taylor, J. W., Hopkins, J. R., Punjabi, S., Oram, D. E., Forster, G., Aruffo, E., Moller, S. J., Bauguitte, S. J.-B., Allan, J. D., Coe, H., and Leigh, R. J.: Ozone photochemistry in boreal biomass burning plumes, Atmos. Chem. Phys., 13, 73217341, doi:10.5194/acp-13-7321-2013, 2013.

Pechony, O. and Shindell, D.: Driving forces of global wildfires over the past millenium and forthcoming century, P. Natl. Acad. Sci., 107, 19167-19170, 2010.

Penner, J. E., Zhou C., and Xu, L.: Consistent estimates from satellites and models for the first aerosol indirect forcing, Geophys. Res. Lett., 39, L13810, doi:10.1029/2012GL051870, 2012.

Perovich, D. K., Richter-Menge, J. A., Jones, K. F., and Light, B.: Sunlight, water, and ice: Extreme Arctic sea ice melt during the summer of 2007, Geophys. Res. Lett., 35, L11501, doi:10.1029/2008GL034007, 2008.

Persad, G. G., Ming, Y., and Ramaswamy, V.: Tropical troposphereonly response to absorbing aerosols, J. Climate, 25, 2471-2480, 2012.

Petäjä, T., Järvi, L., Kerminen, V.-M., Ding. A. J., Sun, J. N., Nie, W., Kujansuu, J., Virkkula, A., Yang, X.-Q., Fu, C. B., Zilitinkevich, S., and Kulmala, M.: Enhanced air pollution via aerosol-boundary layer feedback in China, Sci. Rep., 6, 18998, doi:10.1038/srep18998, 2016.

Phillips, R. P., Finzi, A. C., and Bernhardt, E. S.: Enhanced root exudation induces microbial feedbacks to $\mathrm{N}$ cycling in a pine forest under long-term $\mathrm{CO}_{2}$ fumigation, Ecol. Lett., 14, 187-194, 2011.

Phoenix, G. K. and Bjerke, J. W.: Arctic browning: extreme events and trends reversing arctic greening, Glob. Change Biol., 22, 2960-2962, 2016.

Piao, S., Ciais, P., Friedlingstein, P., Peylin, P., Reichstein, M., Luyssaert, S., Margolis, H., Fang, J., Barr, A., Chen, A., Grelle, A., Hollinger, D. Y., Laurila, T., Lindroth, A., Richardson, A. D., and Vesala, T.: Net carbon dioxide losses of northern ecosystems in response to autumn warming, Nature, 451, 49-53, 2008.

Pithan, F. and Mauritsen, T.: Arctic amplification dominated by temperature feedbacks in contemporary climate models, Nat. Geosci., 7, 181-184, doi:10.1038/ngeo2071, 2014.
Polyakov, I. V., Timokhov, L. A., Alexeev, V. A., Bacon, S., Dmitrenko, I. A., Fortier, L., and Toole, J.: Arctic Ocean warming contributes to reduced polar ice cap, J. Phys. Oceanogr., 40, 2743-2756, 2010.

Pommier, M., Law, K. S., Clerbaux, C., Turquety, S., Hurtmans, D., Hadji-Lazaro, J., Coheur, P.-F., Schlager, H., Ancellet, G., Paris, J.-D., Nédélec, P., Diskin, G. S., Podolske, J. R., Holloway, J. S., and Bernath, P.: IASI carbon monoxide validation over the Arctic during POLARCAT spring and summer campaigns, Atmos. Chem. Phys., 10, 10655-10678, doi:10.5194/acp-1010655-2010, 2010.

Post, W. M., Emanuel, W. R., Zinke, P. J., and Stangenberger, A. G.: Soil carbon pools and world life zones, Nature, 298, 156159, 1982.

Pumpanen, J., Linden, A., Miettinen, H., Kolari, P., Ilvesniemi, H., Mammarella, I., Hari, P., Nikinmaa, E., Heinonsalo, J., Bäck, J., Ojala, A., Berninger, F., and Vesala, T.: Precipitation and net ecosystem exchange are the most important drivers of DOC flux in upland boreal catchments, J. Geophys. Res.-Biogeo., 119, 1861-1878, doi:10.1002/2014JG002705, 2014.

Quinn, P. K. and Bates, T. S.: The case against climate regulation via oceanic phytoplankton sulphur emissions, Nature, 480, 5156, 2011.

Ramonet, M., Ciais, P., Nepomniachii, I., Sidorov, K., Neubert, R. E. M., Picard, D., Kazan, V., Biraud, S. C., Gusti, M., Schulze, E. D., and Lloyd, J.: Three years of aircraft based trace gas measurements over Fyodoroskye southern taiga forest, $300 \mathrm{~km}$ NorthWest of Moscow, Tellus B, 54, 713-734, 2002.

Rampal, P., Weiss, J., Dubois, C., and Campin, J. M.: IPCC climate models do not capture Arctic sea ice drift acceleration: Consequences in terms of projected sea ice thinning and decline, J. Geophys. Res., 116, C00D07, doi:10.1029/2011JC007110, 2011.

Randers, J.: A Global Forecast for the Nextr Forty Years - 2052. A Report to the Club of Rome Commemorating the 40th Aniversary if The Limits to Growth, edited by: Praded, J., Chelsea Green Publishing, Vermont, USA, 395 pp. 2012.

Randersson, J. T., Liu, H., Flanner, M. G., Chambers, S. D., Jin, Y., Hess, P. G., Pfister, G., Mack, M. C., Treseder, K. K., Welp, L. R., Chapin, F. S., Harden, J. W., Goulden, M. L., Lyons, E., Neff, J. C., Schuur, E. A. G., and Zender, C. S.: The impact of boreal forest fire on climate warming, Science, 314, 1130-1132, 2006.

Regnier, P., Friedlingstein, P., Ciais, P., Mackenzie, F. T., Gruber, N., Janssens, I. A., Laruelle, G. G., Lauerwald, R., Luyssaert, S., Andersson, A. J., Arndt, S., Arnosti, A., Borges, A. V., Dale, A. W., Gallego-Sala, A., Goddéris, Y., Goossens, N., Hartmann, J., Heinze, C., Ilyina, T., Joos, F., LaRowe, D. E., Leifeld, J., Meysman, F. J. R., Munhoven, G., Raymond, P. A., Spahni, R., Suntharalingam, P., and Thullner, M.: Anthropogenic perturbation of the carbon fluxes from land to ocean, Nat. Geosci., 6, 597-607, doi:10.1038/NGEO1830, 2013.

Repo, M., Susiluoto, S., Lind, S., Jokinen, S., Elsakov, V., Biasi, C., Virtanen, T., and Martikainen, P. J.: Large $\mathrm{N}_{2} \mathrm{O}$ emissions from cryoturbated peat soil in tundra, Nat. Geosci., 2, 189-192, 2009.

Ribeiro, M., Losenno, C., Dworak, T., Massey, E., Swart, R., Benzie, M., and Laaser, C.: Design of guidelines for the elaboration of Regional Climate Change Adaptation Strategies, Ecologic Institute, Vienna, Austria, 2009. 
Richter, A., Burrows, J. P., Nüszlig, H., Granier, C., and Niemeier, U.: Increase in tropospheric nitrogen dioxide over China observed from space, Nature, 437, 129-132, doi:10.1038/nature04092, 2005.

Roiger, A., Thomas, J. L., Schlager, H., Law, K. S., Kim, J., Schafler, A., Weinzierl, B., Dahlkotter, F., Krisch, I., Marelle, L., Minikin, A., Raut, J. C., Reiter, A., Rose, M., Scheibe, M., Stock, P., Baumann, R., Bouarar, I., Clerbaux, C., George, M., Onishi, $\mathrm{T}$., and Flemming J.: Quantifying emerging local anthropogenic emissions in the Arctic region: The ACCESS aircraft campaign experiment, B. Am. Meteorol. Soc., 96, 441-460, 2015.

Romanovsky, V., Burgess, M., Smith, S., Yoshikawa, K., and Brown, J.: Permafrost temperature records: Indicators of climate change, EOS, 83, 589-594, 2002.

Rosenfeld, D., Andreae, M. O., Asmi, A., Chin, M., de Leeuw, G., Donovan, D., Kahn, R., Kinne, S., Kivekäs, N., Kulmala, M., Lau, W., Schmidt, S., Suni, T., Wagner, T., Wild, M., and Quaas, J.: Global observations of aerosol-cloudprecipitation-climate interactions, Rev. Geophys., 52, 750-808, doi:10.1002/2013RG000441, 2014.

Rosenfeld, D., Zheng, Y., Hashimshoni, E., Pöhlker, M. L., Jefferson, A., Pöhlker, C., Yu, X., Zhu, Y., Liu, G., Yue, Z., Fischman, B., Li, Z., Giguzin, D., Goren, T., Artaxo, P., Barbosa, H. M. J., Pöschl, U., and Andreae, M. O.: Satellite retrieval of cloud condensation nuclei concentrations by using clouds as CCN chambers, P. Natl. Acad. Sci., 113, 5828-5834, doi:10.1073/pnas.1514044113, 2016.

Rudneva, N. A., Pronin, N., and Rudneva, M. L. V.: Microelements and heavy metals in the muscles of the Muskrat (Ondatra Zibethica) from the Selenga river delta, Russ. J. Ecol.+, 36, 435-437, 2005.

Ryshkevich, T. I., Mironov, G. N., Mironova, S. Y., Vlasenko, S. S., Chi, X., Andreae, M. O., and Mikhailov, E. F.: Comparative analysis of hygroscopic properties of atmospheric aerosols at ZOTTO Siberian background station during summer and winter campaigns of 2011, Izv. Atmos. Ocean. Phy.+, 51, 512-519, 2015.

Saeki, T., Maksyutov, S., Sasakawa, M., Machida, T., Arshinov, M., Tans, P. J., Conway, T., Saito, M., Valsala, V., Oda, T., Andres, R. J., and Belikov D.: Carbon flux estimation for Siberia by inverse modeling constrained by aircraft and tower $\mathrm{CO}_{2}$ measurements, J. Geophys. Res., 118, 1100-1122, doi:10.1002/jgrd.50127, 2013.

Sahoo, A. K., Pan, M., Troy, T. J., Vinukollu, R., Sheffield, J., and Wood, E. F.: Reconciling the global terrestrial water budget using satellite remote sensing, Remote Sens. Environ., 115, 18501865, doi:10.1016/j.rse.2011.03.009, 2011.

Sanderson, M. G., Collins, W. J., Johnson, C. E., and Derwent, R. G.: Present and future acid deposition to ecosystems: the effect of climate change, Atmos. Environ., 40, 1275-1283, 2006.

Sasakawa, M., Shimoyama, K., Machida, T., Tsuda, N., Suto, H., Arshinov, M., Davydov, D., Fofonov, A., Krasnov, O., Saeki, T., Koyama, Y., and Maksyutov, S.: Continuous measurements of methane from a tower network over Siberia, Tellus B, 62, 403416, doi:10.1111/j.1600-0889.2010.00494.x, 2010.

Savva, Y. and Berninger, F.: Sulphur deposition causes a large scale growth decline in boreal forests in Eurasia, Global Biogeochem. Cy., 24, GB3002, doi:10.1029/2009GB003749, 2010.
Schellnhuber, J., Cruzen, P., Clark, W., Claussen, M., and Held, H. (Eds.): Earth System Analysis for Sustainability, Dahlem Workshop on Earth System Analysis for Sustainability, Berlin, Germany, 25-30 May 2003, MIT Press, 454 pp., 2004.

Schepaschenko, D., McCallum, I., Shvidenko, A., Fritz, S., Kraxner, F., and Obersteiner, M.: A new hybrid land cover dataset for Russia: a methodology for integrating statistics, remote sensing and in situ information, J. Land Use Sci., 6, 245-259, 2011.

Schepaschenko, D. G., Mukhortova, L. V., Shvidenko, A. Z., and Vedrova, E. F.: The pool of organic carbon in the soils of Russia, Eurasian Soil Sci.+, 46, 107-116, 2013.

Schepaschenko, D. G., Shvidenko, A. Z., Lesiv, M. V., Ontikov, P. V., Schepaschenko, M. V., and Kraxner, F.: Area of Russia's forests and its dynamics based on synthesis of remote sensing products, Forest Science, 3, 163-171, 2015 (in Russian).

Schindler, D. W.: The cumulative effects of climate warming and other human stresses on Canadian freshwaters in the new millennium, Can. J. Fish. Aquat. Sci., 58, 18-29, 2001.

Schlesinger, W. H.: Biogeochemistry: an analysis of global change, 2nd ed. Academic Press, San Diego, California, USA, 1997.

Schuur, E. A. G., Vogel, J. G., Crummer, K. G., Lee, H., Sickman, J. O., and Osterkamp, T. E.: The effect of permafrost thaw on old carbon release and net carbon exchange from tundra, Nature, 556-559, 2009.

Scott, C. E., Rap, A., Spracklen, D. V., Forster, P. M., Carslaw, K. S., Mann, G. W., Pringle, K. J., Kivekäs, N., Kulmala, M., Lihavainen, H., and Tunved, P.: The direct and indirect radiative effects of biogenic secondary organic aerosol, Atmos. Chem. Phys., 14, 447-470, doi:10.5194/acp-14-447-2014, 2014.

Screen, J. A. and Simmonds, I.: Increasing fall-winter energy loss from the Arctic Ocean and its role in Arctic temperature amplification, Geophys. Res. Lett., 37, L16707, doi:10.1029/2010GL044136, 2010.

Screen, J. A. and Simmonds, I.: Declining summer snowfall in the Arctic: causes, impacts and feedbacks, Clim. Dynam., 38, 22432256, doi:10.1007/s00382-011-1105-2, 2012.

Sedlar, J., Tjernström, M., Mauritsen, T., Shupe, M., Brooks, I., Persson, P. O. G., Birch, C. E., Leck, C., Sirevaag, A., and Nicolaus, M.: A transitioning Arctic surface energy budget: the impacts of solar zenith angle, surface albedo and cloud radiative forcing, Clim. Dynam., 37, 1643-1660, doi:10.1007/s00382010-0937-5, 2011.

Sellers, P. J., Dickinson, R. E., Randall, D. A., Betts, A. K., Hall, F. G., Berry, J. A., Collatz, G. J., Denning, A. S., Mooney, H. A., Nobre, C. A., Sato, N., Field, C. B., and Henderson-Sellers, A.: Modeling the exchanges of energy, water, and carbon between continents and the atmosphere, Science, 24, 502-509, doi:10.1126/science.275.5299.502, 1997.

Semiletov, I. P., Pipko, I. I., Shakhova, N. E., Dudarev, O. V., Pugach, S. P., Charkin, A. N., McRoy, C. P., Kosmach, D., and Gustafsson, Ö.: Carbon transport by the Lena River from its headwaters to the Arctic Ocean, with emphasis on fluvial input of terrestrial particulate organic carbon vs. carbon transport by coastal erosion, Biogeosciences, 8, 2407-2426, doi:10.5194/bg8-2407-2011, 2011.

Sereda, J., Bogard, M., Hudson, J., Helps, D., and Dessouki, T.: Climate warming and the onset of salinization: rapid changes in the limnology of two northern plains lakes, Limnologica, 41, 19, 2011. 
Shakhova, N., Semiletov, I., Salyuk, A., Yusupov, V., Kosmach, D., and Gustafsson, O.: Extensive methane venting to the atmosphere from sediments of the East Siberian Arctic Shelf, Science, 327, 1246-1250, 2010.

Shatalina, M. V., Mareev, E. A, Anisimov, S. V., and Shikhova, N. M.: Modeling of the Electric-Field Dynamics in the Atmosphere Using the Test-Structure Method, Radiophys. Quantum El., 48, 575-586, doi:10.1007/s11141-005-0102-x, 2005.

Shatalina, M. V., Mareev, E. A., Anisimov, S. V., and Shikhova, N. M.: Recovery of space charge distribution by the method of test structures, in: Proc. Int. Conf. Atm. Electr, ICAE 07, 1317 August 2007, Beijing, China, 2007.

Sheffield, J., Wood, E. F., and Munoz-Arriola, F.: Long-term regional estimates of evapotranspiration for Mexico based on downscaled ISCCP data, J. Hydrometeorol., 11, 253-275, 2010.

Shindell, D. and Faluvegi, G.: climate response to regional radiative forcing during the twentieth century, Nat. Geosci., 2, 294-300, 2009.

Shmakin, A. B. and Popova, V. V.: Dynamics of climate extremes in northern Eurasia in the late 20th century, Izv. Atmos. Ocean. Phy.+, 42, 157-166, 2006.

Shuntov, V. P., Dulepova, E. G., Temnih, O. C., Volkov, A. F., Naydenko, S. V., Chuchukalo, V. I., and Volkov, I. V.: Condition of biological resources in relation to dymanmics of macroecosystems in economic zone of Russian Far East Seas, Dynamics of the ecosystems and contemporary problems of conservation of potential bioresources of Russian Seas, chap. 2, Vladivostok, Dalnauka, Russia, 75-176, 2007.

Shvidenko, A., Schepaschenko, D., McCallum, I., and Nilsson, S.: Can the uncertainty of full carbon accounting of forest ecosystems be made acceptable to policy makers?, Climatic Change, 103, 137-157, 2010.

Shvidenko, A., Schepaschenko, D., Vaganov, E. A., Sukhinin, A. I., Maksyutov, Sh. Sh., McCallum, I., and Lakyda, I. P.: Impacts of wildfire in Russia between 1998-2010 on ecosystems and the global carbon budget, Proc. Russian Academy of Sciences (Doklady Earth Sciences), 441, 1678-1682, 2011.

Shvidenko, A., Gustafson, E., McGuire, A. D., Kharuk, V. I., Svhepaschenko, D. G., Shugart, H. H., Tchebakova, N. M., Vygodskaya, N. N., Onuchin, A. A., Hayes, D. J., McCallum, I., Maksyutov, S., Mukhortova, L. V., Soja, A. J., BelelliMarchesini, L., Kurbatova, J. A., Oltchev, A. V., Parfenova, E. I., and Shuman, J. K.: Terrestrial ecosystems and their change, in: Regional Environmental Changes in Siberia and their Global Consequences, edited by: Groisman, P. Y. and Gutman, G., Springer Science + Business Media, Dordrecht, the Netherlands, 171-249, 2013a.

Shvidenko, A., Schepaschenko, D., Kraxner, F., and Obersteiner, M.: Terrestrial ecosystems full carbon account as a fuzzy system: An attempt to understand uncertainties, in: 9th Int. $\mathrm{CO}_{2}$ Conf., 3-7 June 2013, Beijing, China, 2013b.

Shvidenko, A. Z. and Schepaschenko, D. G.: Climate change and wildfires in Russia, Contemp. Probl. Ecol., 6, 683-692, 2013.

Shvidenko, A. Z. and Schepaschenko, D. G.: Carbon budget of Russian forests, Sibirskij Lesnoj Zurnal (Siberian Journal of Forest Science), 1, 69-92, 2014 (in Russian with English abstract).

Singh, D., Singh, R., and Kamra, A. The Electrical Environment of the Earth's Atmosphere: A Review, Space Sci. Rev., 113, 375408, 2004.
Singh, H. B., Brune, W. H., Crawford, J. H., Jacob, D. J., and Russell, P. B.: Overview of the summer 2004 Intercontinental Chemical Transport Experiment-North America (INTEX-A), J. Geophys. Res., 111, D24S01, doi:10.1029/2006JD007905, 2006.

Skjelkvåle, B. L., and Wright, R. F.: Mountain lakes; sensitivity to acid deposition and global climate change, Ambio, 27, 280-286, 1998.

Skjelkvåle, B. L., Stoddard, J. L., and Andersen, T.: Trends in surface water acidification in Europe and North America (19891998), Water Air Soil Poll., 130, 787-792, 2001.

Skryzhevska, Y., Tynkkynen, V.-P., and Leppänen, S.: Russia's climate policies and local reality, Polar Geography, 38, 146-170, 2015.

Smedsrud, L., Esau, I., Ingvaldsen, R., Eldevik, T., Haugan, P., Li, C., Lien, V., Olsen, A., Omar, A., Otterå, O., Risebrobakken, B., Sand $\varnothing$, A., Semenov, V., and Sorokina, S.: The role of the Barents Sea in the Arctic climate system, Rev. Geophys., 51, 1-35, 2013.

Smith, L. C.: The World in 2050: Four forces shaping civilization's northern future, Brockman Inc., Clays, Bungay, Suffolk, 2010.

Smith, L. C., Sheng, Y., MacDonald, G. M., and Hinzman, L. D.: Disappearing arctic lakes, Science, 308, 1429, doi:10.1126/science.1108142, 2005.

Smith, S. J., Pitcher, H., and Wigley, T. M. L.: Global and Regional Anthropogenic Sulfur Dioxide Emissions, Global Planet. Change, 29, 99-119, 2001.

Smith, S. J., van Aardenne, J., Klimont, Z., Andres, R. J., Volke, A., and Delgado Arias, S.: Anthropogenic sulfur dioxide emissions: 1850-2005, Atmos. Chem. Phys., 11, 1101-1116, doi:10.5194/acp-11-1101-2011, 2011.

Sofiev, M., Vankevich, R., Ermakova, T., and Hakkarainen, J.: Global mapping of maximum emission heights and resulting vertical profiles of wildfire emissions, Atmos. Chem. Phys., 13, 7039-7052, doi:10.5194/acp-13-7039-2013, 2013.

Sorooshian, S., Hsu, K. L., Gao, X., Gupta, H. V., Imam, B., and Braithwaite, D.: Evaluation of PERSIANN system satellitebased estimates of tropical rainfall, B. Am. Meteorol. Soc., 81, 2035-2046, 2000.

Spracklen, D. V. and Heald, C. L.: The contribution of fungal spores and bacteria to regional and global aerosol number and ice nucleation immersion freezing rates, Atmos. Chem. Phys., 14, 90519059, doi:10.5194/acp-14-9051-2014, 2014.

Spracklen, D. V., Bonn B., and Carslaw, K. S.: Boreas forests, aerosols and the impacts on clouds and climate, Philos. T. R. Soc., 266A, 1-11, doi:10.1098/rsta.2008.0201, 2008.

State Report: State Report on State and Protection of Environment of the Russian Federation in 2011, Roshydromet, Moscow, Russia, 2011.

Stavrakou, T., Müller, J.-F., Peeters, J., Razavi, A., Clarisse, L., Clerbaux, C., Coheur, P.-F., Hurtmans, D., De Mazière, M., Vigouroux, C., Deutscher, N. M., Griffith, D. W. T., Jones, N., and Paton-Walsh, C.: Satellite evidence for a large source of formic acid from boreal and tropical forests, Nat. Geosci., 5, 2630, doi:10.1038/ngeo1354, 2012.

Stavrakou, T., Müller, J.-F., Bauwens, M., De Smedt, I., Van Roozendael, M., Guenther, A., Wild, M., and Xia, X.: Isoprene emissions over Asia 1979-2012: impact of climate and land-use changes, Atmos. Chem. Phys., 14, 4587-4605, doi:10.5194/acp14-4587-2014, 2014. 
Stohl, A.: Characteristics of atmospheric transport into the Arctic troposphere, J. Geophys. Res., 111, D11306, doi:10.1029/2005JD006888, 2006.

Stroeve, J. C., Serreze, M. C., Holland, M. M., Kay, J. E., Maslanik, J., and Barrett, A. P.: The Arctic's rapidly shrinking sea ice cover: a research synthesis, Climatic Change, 110, 1005-1027, doi:10.1007/s10584-011-0101-1, 2012.

Struthers, H., Ekman, A. M. L., Glantz, P., Iversen, T., Kirkevåg, A., Mårtensson, E. M., Seland, Ø., and Nilsson, E. D.: The effect of sea ice loss on sea salt aerosol concentrations and the radiative balance in the Arctic, Atmos. Chem. Phys., 11, 3459-3477, doi:10.5194/acp-11-3459-2011, 2011.

Su, H., Wood, E. F., McCabe, M. F., and Su, Z.: Evaluation of remotely sensedbevapotranspiration over the CEOP EOP-1 reference sites, J. Meteorol. Soc. Jpn., 85A, 439-459, 2007.

Su, H., Cheng, Y., Oswald, R., Behrendt, T., Trebs, I., Meixner, F. X., Andreae, M. O., Cheng, P., Zhang, Y., and Pöschl, U.: Soil nitrite as a source of atmospheric $\mathrm{HONO}$ and $\mathrm{OH}$ radicals, Science, 333, 1616-1618, 2011.

Sun, H., Santalahti, M., Pumpanen, J., Köster, K., Berninger, F., Raffaello, T., Jumpponen, A., Asiegbu, F. O., and Heinonsalo, J.: Fungal community shifts in structure and function across a boreal forest fire chronosequence, Appl. Environ. Microb., 81, 7869-7880, 2015.

Sun, Z., Niinemets, Ü., Hüve, K., Rasulov, B., and Noe, S. M.: Elevated atmospheric $\mathrm{CO}_{2}$ concentration leads to increased whole-plant isoprene emission in hybrid aspen (Рориlus tremula $x$ Populus tremuloides), New Phytol., 198, 788-800, doi:10.1111/nph.12200, 2013.

Sutton, M. A., Howard, C. M., Willem Erisman, J., Billen, G., Bleeker, A., Grennfelt, P., van Grinsven, H., and Grizzetti, B. (Eds.): European Nitrogen Assessment, Cambridge University Press, Cambridge, UK, 2010.

Tarnocai, C., Canadell, J. G., Schuur, E. A. G., Kuhry, P., Mazhitova, G., and Zimov, S.: Soil organic carbon pools in the northern circumpolar permafrost region, Global Biogeochem. Cy., 23, GB2023, doi:10.1029/2008GB003327, 2009.

Tchebakova, N. M., Parfenova, E. I., and Soja, A. J.: Effect of climate, permafrost and fire on vegetation change in Siberia in a changing climate, Environ. Res. Lett., 4, 045013, doi:10.1088/1748-9326/4/4/045013, 2009.

Tikkanen, E.: Conclusions, in: Kola Peninsula pollutants and forest ecosystems in Lapland, edited by: Tikkanen, E. and Niemelä, I., Final report of the Lapland Forest Damage Project. Finland's Ministry of Agriculture and Forestry, The Finnish Forest Research Institute, Gummerus Kirjapaino Oy, Jyväskylä, 71-81, 1995.

Tishkov, A. A.: Biogeographical Consequences of Natural and Anthropogenic Climate Changes, Biol. Bull. Rev., 2, 132-140, 2012.

Tjernström, M., Leck, C., Birch, C. E., Bottenheim, J. W., Brooks, B. J., Brooks, I. M., Bäcklin, L., Chang, R. Y.-W., de Leeuw, G., Di Liberto, L., de la Rosa, S., Granath, E., Graus, M., Hansel, A., Heintzenberg, J., Held, A., Hind, A., Johnston, P., Knulst, J., Martin, M., Matrai, P. A., Mauritsen, T., Müller, M., Norris, S. J., Orellana, M. V., Orsini, D. A., Paatero, J., Persson, P. O. G., Gao, Q., Rauschenberg, C., Ristovski, Z., Sedlar, J., Shupe, M. D., Sierau, B., Sirevaag, A., Sjogren, S., Stetzer, O., Swietlicki, E., Szczodrak, M., Vaattovaara, P., Wahlberg, N., Westberg, M., and
Wheeler, C. R.: The Arctic Summer Cloud Ocean Study (ASCOS): overview and experimental design, Atmos. Chem. Phys., 14, 2823-2869, doi:10.5194/acp-14-2823-2014, 2014.

Troitskaya, Y., Rybushkina, G., Soustova, I., Balandina, G., Lebedev, S., and Kostianoy, A.: Adaptive retracking of Jason1 altimetry data for inland waters: the example of the Gorky Reservoir, Int. J. Remote Sens., 33, 7559-7578, 2012.

Troitskaya, Y., Troitskaya, Y., Ezhova, E. V., Sergeev, D. A., Kandaurov, A. A., Baidakov, G. A., Vdovin, M. I., and Zilitinkevich, S.: Momentum and buoyancy transfer in atmospheric turbulent boundary layer over wavy water surface. Part 2: Windwavespectra, Nonlinear Proc. Geoph., 20, 841-856, 2013.

Tunved, P., Hansson, H.-C., Kerminen, V.-M., Ström, J., Dal Maso, M., Lihavainen, H., Viisanen, Y., Aalto, P. P., Komppula, M., and Kulmala, M.: High natural aerosol loading over boreal forests, Science, 312, 261-263, 2006.

Tynkkynen, V.-P.: From mute to reflective: Changing governmentality in St Petersburg and the priorities of Russian environmental planning, J. Environ. Plann. Man., 53, 1-16, 2010.

United Nations Environment Program: UNEP Year Book 2013: Emerging issues in our global environment, edited by: Goverse, T., Nairobi, Kenya, ISBN: 978-92-807-3284-9, 78 pp., 2013.

Uppala, S. M., Kållberg, P. W., Simmons, A. J., Andrae, U., Da Costa Bechtold, V., Fiorino, M., Gibson, J. K., Haseler, J., Hernandez, A., Kelly, G. A., Li, X., Onogi, K., Saarinen, S., Sokka, N., Allan, R. P., Andersson, E., Arpe, K., Balmaseda, M. A., Beljaars, A. C. M., Van De Berg, L., Bidlot, L., Bormann, N., Caires, S., Chevallier, F., Dethof, A., Dragosavac, M., Fisher, M., Fuentes, M., Hagemann, S., Hólm, E., Hoskins, B. J., Isaksen, L., Janssen, P. A. E. M., Jenne, R., Mcnally, A. P., Mahfouf, J. F., Morcrette, J.-J., Rayner, N. A., Saunders, R. W., Simon, P., Sterl, A., Trenberth, K. E., Untch, A., Vasiljevic, D., Viterbo, P., and Woollen, J.: The ERA-40 re-analysis, Q. J. Roy. Meteor. Soc., 131, 2961-3012, doi:10.1256/qj.04.176, 2005.

Uttal, T., Starkweather, S., Drummond, J., Vihma, T., Makshtas, A., Darby, L., Burkhart, J., Cox, C., Schmeisser, L., Haiden, T., Maturilli, M. D., Shupe, M., de Boer, G., Saha, A., Grachev, A., Crepinsek, S., Bruhwiler, L., Goodison, B., McArthur, B., Walden, V., Dlugokencky, E., Persson, O., Lesins, G., Laurila, T., Ogren, J., Stone, R., Long, C., Sharma, S., Massling, A., Turner,D., Stanitski, D., Asmi, E., Aurela, M., Skov, H., Eleftheriadis, K., Virkkula, A., Platt, A., Førland, E., Iijima, Y., Nielsen, I., Bergin, M., Candlish, L., Zimov, N., Zimov, S., O’Neill, N., Fogal P., Kivi, R., Konopleva-Akish, E. A., Verlinde, J., Kustov, V. Y., Vasel, B., Ivakhov, V. M., Viisanen,Y., and Intrieri, J. M.: International Arctic Systems for Observing the Atmosphere (IASOA): An International Polar Year Legacy Consortium, B. Am. Meteorol. Soc., 1034-1056, doi:10.1175/BAMS-D-14-00145.1, 2015.

van der Werf, G. R., Randerson, J. T., Giglio, L., Collatz, G. J., Kasibhatla, P. S., and Arellano Jr., A. F.: Interannual variability in global biomass burning emissions from 1997 to 2004, Atmos. Chem. Phys., 6, 3423-3441, doi:10.5194/acp-6-3423-2006, 2006.

van Donkelaar, A., Martin, R. V., Brauer, M., and Boys, B. L.: Use of Satellite Observations for Long-Term Exposure Assessment of Global Concentrations of Fine Particulate Matter, Environ. Health Persp., 123, 135-143, doi:10.1289/ehp.1408646, 2015. 
Vaschuk, L. N. and Shvidenko, A. Z.: Dynamics of forests of Irkutsk region, Irkutsk, Russia, 2006 (in Russian).

Vavrus, S., Waliser, D., Schweiger, A., and Francis, J.: Simulations of 20th and 21st century Arctic cloud amount in the global climate models assessed in the IPCC AR4, Clim. Dynam., 12, 1099-1115, doi:10.1007/s00382-008-0475-6, 2009.

Velicogna, I., Tong, J., Zhang, T., and Kimball, J. S.: Increasing subsurface water storage in discontinuous permafrost areas of the Lena River basin, Eurasia, detected from GRACE, Geophys. Res. Lett., 39, L09403, doi:10.1029/2012GL051623, 2012.

Verstraeten, W. W., Neu, J. L., Williams, J. E., Bowman, K. W., Worden, J. R., and Boersma, K. F.: Rapid increases in tropospheric ozone production and export from China, Nat. Geosci. 8, 690-695, doi:10.1038/ngeo2493, 2015.

Vesala, T., Launiainen, S., Kolari, P., Pumpanen, J., Sevanto, S., Hari, P., Nikinmaa, E., Kaski, P., Mannila, H., Ukkonen, E., Piao, S. L., and Ciais, P.: Autumn temperature and carbon balance of a boreal Scots pine forest in Southern Finland, Biogeosciences, 7 , 163-176, doi:10.5194/bg-7-163-2010, 2010.

Vesala, T., Eugster, W., and Ojala, A.: Eddy Covariance Measurements over Lakes, in: Eddy Covariance - A practical guide to measurements and data analysis, edited by: Aubinet, M., Vesala, T., and Papale, D., Springer Science + Business Media B.V, Dordrecht, the Netherlands, 365-376, 2012.

Vihma, T.: Effects of Arctic sea ice decline on weather and climate: a review, Surv. Geophys., 35, 1175-1214, doi:10.1007/s10712014-9284-0, 2014.

Vihma, T., Tisler, P., and Uotila, P.: Atmospheric forcing on the drift of Arctic sea ice in 1989-2009, Geophys. Res. Lett., 39, L02501, doi:10.1029/2011GL050118, 2012.

Vihma, T., Pirazzini, R., Fer, I., Renfrew, I. A., Sedlar, J., Tjernström, M., Lüpkes, C., Nygård, T., Notz, D., Weiss, J., Marsan, D., Cheng, B., Birnbaum, G., Gerland, S., Chechin, D., and Gascard, J. C.: Advances in understanding and parameterization of small-scale physical processes in the marine Arctic climate system: a review, Atmos. Chem. Phys., 14, 9403-9450, doi:10.5194/acp-14-9403-2014, 2014.

Virtanen, T. H., Kolmonen, P., Rodríguez, E., Sogacheva, L., Sundström, A.-M., and de Leeuw, G.: Ash plume top height estimation using AATSR, Atmos. Meas. Tech., 7, 2437-2456, doi:10.5194/amt-7-2437-2014, 2014.

Vitousek, P. M., Mooney, H. A., Lubchenco, J., and Melillo, J. M.: Human domination of Earth's ecosystems, Science, 277, 494499, 1997a.

Vitousek, P. M., Aber, J. D., Howarth, R. W., Likens, G. E., Matson, P. A., Schindler, D. W., Schlesinger, W. H., and Tilman, D. G.: Human alteration of the global nitrogen cycle: sources and consequences, Ecol. Appl., 7, 737-750, 1997b.

Vitousek, P. M., Porder, S., Houlton, B. Z., and Chadwick, O. A.: Terrestrial phosphorus limitation: mechanisms, implications, and nitrogen-phosphorus interactions, Ecol. Appl., 20, 5-15, 2010.

Vivchar, A. V., Moiseenko, K. B., Shumskii, R. A., and Skorokhod, A. I.: Identifying anthropogenic sources of nitrogen oxide emissions from calculations of Lagrangian trajectories and the observational data from a tall tower in Siberia during the springsummer period of 2007: Izv. Atmos. Ocean. Phy.+, 45, 302-313, doi:10.1134/s0001433809030049, 2009.

Vonk, J. E., Sánchez-García, L., van Dongen, B. E., Alling, V., Kosmach, D., Charkin, A., Semiletov, I. P., Dudarev, O. V.,
Shakhova, N., Roos, P., Eglinton, T. I., Andersson, A., and Gustafsson, Ö.: Activation of old carbon by erosion of coastal and subsea permafrost in Arctic Siberia, Nature, 489, 137-140, 2012.

Walter, K. M., Zimov, S. A., Chanton, J. P., Verbyla, D., and Chapin III, F. S.: Methane bubbling from Siberian thaw lakes as a positive feedback to climate warming, Nature, 443, 71-75, doi:10.1038/nature05040, 2006.

Wang, R., Balkanski, Y., Boucher, O., Ciais, P., Peñuelas, J., and Tao, S.: Significant contribution of combustion-related emissions to the atmospheric phosphorus budget, Nature, 8, 48-54, doi:10.1038/ngeo2324, 2014.

Wang, T., Wei, X. L., Ding, A. J., Poon, C. N., Lam, K. S., Li, Y. S., Chan, L. Y., and Anson, M.: Increasing surface ozone concentrations in the background atmosphere of Southern China, 19942007, Atmos. Chem. Phys., 9, 6217-6227, doi:10.5194/acp-96217-2009, 2009.

Warneke, C., Bahreini, R., Brioude, J., Brock, C. A., de Gouw, J. A., Fahey, D. W., Froyd, K. D., Holloway, J. S., Middlebrook, A., Miller, L., Montzka, S., Murphy, D. M., Peischl, J., Ryerson, T. B., Schwarz, J. P., Spackman, J. R., and Veres, P.: Biomass burning in Siberia and Kazakhstan as an important source for haze over the Alaskan Arctic in April 2008, Geophys. Res. Lett., 36, L02813, doi:10.1029/2008GL036194, 2009.

Wespes, C., Emmons, L., Edwards, D. P., Hannigan, J., Hurtmans, D., Saunois, M., Coheur, P.-F., Clerbaux, C., Coffey, M. T., Batchelor, R. L., Lindenmaier, R., Strong, K., Weinheimer, A. J., Nowak, J. B., Ryerson, T. B., Crounse, J. D., and Wennberg, P. O.: Analysis of ozone and nitric acid in spring and summer Arctic pollution using aircraft, ground-based, satellite observations and MOZART-4 model: source attribution and partitioning, Atmos. Chem. Phys., 12, 237-259, doi:10.5194/acp-12-237-2012, 2012.

Whitehead, P. G. and Crossman, J.: Macronutrient cycles and climate change: key science areas and an international perspective, Sci. Total Environ., 434, 13-17, 2012.

Wolf, T. and Esau, I.: Air quality hazards under present and future climate conditions in Bergen, Norway, Urban Climate, 10, 801814, doi:10.1016/j.uclim.2014.10.006, 2014.

Wolf, T., Esau, I., and Reuder, J.: Analysis of the vertical temperature structure in the Bergen valley, Norway, and its connection to pollution episodes, J. Geophys. Res.-Atmos., 119, 10645-10662, doi:10.1002/2014JD022085, 2014.

Xu, L., Guo, H., Boyd, C. M., Klein, M., Bougiatioti, A., Cerully, K. M., Hite, J. R., Isaacman-VanWertz, G., Kreisberg, N. M., Knote, C., Olson, K., Koss, A., Goldstein, A. H., Hering, S. V., de Gouw, J., Baumann, K., Lee, S. H., Rodney, A. N., Weber, R. J., and Ng, N. L.: Effects of anthropogenic emissions on aerosol formation from isoprene and monoterpenes in the southeastern United States, P. Natl. Acad. Sci. USA, 112, 37-42, 2015.

Yvon-Durocher, G., Caffrey, J. M., Cescatti, A., Dossena, M., del Giorgio, P., Gasol, J. M., Montoya, J. M., Pumpanen, J., Staehr, P. A., Trimmer, M., Woodward, G., and Allen, A. P.: Reconciling the temperature dependence of respiration across timescales and ecosystem types, Nature, 487, 472-476, doi:10.1038/nature11205, 2012.

Zábori, J., Krejci, R., Ekman, A. M. L., Mårtensson, E. M., Ström, J., de Leeuw, G., and Nilsson, E. D.: Wintertime Arctic Ocean sea water properties and primary marine aerosol concentrations, 
Atmos. Chem. Phys., 12, 10405-10421, doi:10.5194/acp-1210405-2012, 2012.

Zábori, J., Krejci, R., Ström, J., Vaattovaara, P., Ekman, A. M. L., Salter, M. E., Mårtensson, E. M., and Nilsson, E. D.: Comparison between summertime and wintertime Arctic Ocean primary marine aerosol properties, Atmos. Chem. Phys., 13, 4783-4799, doi:10.5194/acp-13-4783-2013, 2013.

Zaehle, S., Ciais, P., Friend, A. D., and Prieur, V.: Carbon benefits of anthropogenic reactive nitrogen offset by nitrous oxide emissions, Nat. Geosci., 4, 601-605, 2011.

Zheng, G. J., Duan, F. K., Su, H., Ma, Y. L., Cheng, Y., Zheng, B., Zhang, Q., Huang, T., Kimoto, T., Chang, D., Pöschl, U., Cheng, Y. F., and He, K. B.: Exploring the severe winter haze in Beijing: the impact of synoptic weather, regional transport and heterogeneous reactions, Atmos. Chem. Phys., 15, 2969-2983, doi:10.5194/acp-15-2969-2015, 2015.

Zhou, L., Tucker, C. J., Kaufmann, R. K., Slayback, D., Shabanov, N. V., Fung, I., and Myneni, R. B.: Variations in northern vegetation activity inferred from satellite data of vegetation index during 1981 to 1999, J. Geophys. Res., 106, 20069-20083, 2001.

Zieger, P., Aalto, P. P., Aaltonen, V., Äijälä, M., Backman, J., Hong, J., Komppula, M., Krejci, R., Laborde, M., Lampilahti, J., de Leeuw, G., Pfüller, A., Rosati, B., Tesche, M., Tunved, P., Väänänen, R., and Petäjä, T.: Low hygroscopic scattering enhancement of boreal aerosol and the implications for a columnar optical closure study, Atmos. Chem. Phys., 15, 7247-7267, doi:10.5194/acp-15-7247-2015, 2015.
Zilitinkevich, S., Esau, I., and Baklanov, A.: Further comments on the equilibrium height of neutral and stable planetary boundary layers, Q. J. Roy. Meteor. Soc., 133, 265-271, 2007.

Zilitinkevich, S., Kulmala, M., Esau, I., and Baklanov, A.: Megacities - refining models to personal environment, WMO Bulletin, 64, 20-22, 2015.

Zilitinkevich, S. S.: Turbulent Penetrative Convection, Avebury Technical, Aldershot, UK, 1991.

Zilitinkevich S. S.: The Height of the Atmospheric Planetary Boundary layer: State of the Art and New Development chap. 13 in: National Security and Human Health Implications of Climate Change, edited by: Fernando, H. J. S., Klaić, Z., McKulley, J. L., NATO Science for Peace and Security Series - C: Environmental Security (ISBN 978-94-007-2429-7), Springer, Dordrecht, the Netherlands, 147-161, 2012.

Zilitinkevich, S. S. and Esau, I. N.: Planetary boundary layer feedbacks in climate system and triggering global warming in the night, in winter and at high latitudes, Geography, Environment and Sustainability, 1, 20-34, doi:10.1002/qj.27, 2009.

Zolotokrylin, R., Titkova, T. B., Cherenkova, E. A., and Vinogradova, V. V.: Satellite index for evaluation of climatic extremes in dru areas, Mod. Stud. Earth Remote Sens. Sp., 9, 114-121, 2012 (in Russian). 